UNITED STATES DEPARTMENT OF THE INTERIOR GEOLOGICAL SURVEY

\title{
SEDIMENTOLOGY AND STRATIGRAPHY OF THE KANAYUT CONGLOMERATE, CENTRAL BROOKS RANGE, ALASKA--REPORT OF 1980 FIELD SEASON
}

By

T. H. Nilsen, T. E. Moore, D. F. Balin, and S. Y. Johnson

Open-File Report 82-199

1982

This report is preliminary and has not been reviewed for conformity with U.S. Geological Survey editorial standards and stratigraphic nomenclature. 
Page

Abstract ........................................... 1

Introduction ............................................

Purpose and scope...................................

Stratigraphy ......................................... 3

Distribution and structure........................... 7

Acknowledgments .................................... 8

Sedimentary facies...................................... 8

General........................................... 8

Hunt Fork Shale and basal sandstone member of the

Kanayut Conglomerate............................. 8

Kanayut Conglomerate..................................9

Kayak Shale.......................................... 11

Measured sections ...................................... 12

Atigun Pass area......................................12

Lower shale member.................................. 12

Middle conglomerate member..........................23

St uver Member.................................... 25

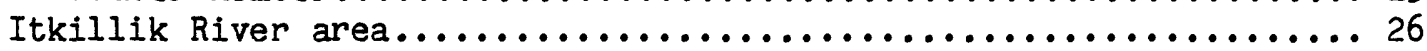

Lower shale member ................................. 26

Shainin Lake area ....................................... 35

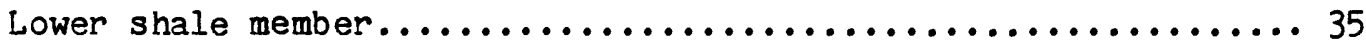

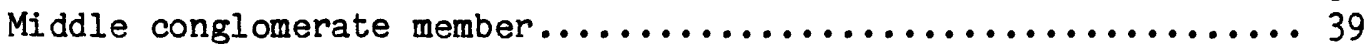

Anaktuvuk Pass area....................................43

Middle conglomerate member, Anaktuvuk River...............43

Kanayut Conglomerate, John River....................... 45

Mount MacVicar area...................................51

Lower shale member................................... 51

Okokmilaga Valley area ................................. 51

Lower shale member................................. 51

Stuver Member.................................... 55

Killik River area ..................................... 58

Lower shale and middle conglomerate member................ 58

Conglomerate clast size data................................ 64

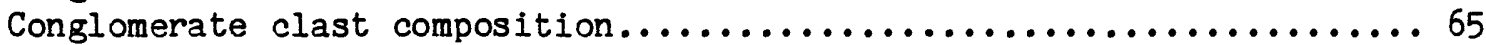

Introduction ...................................... 65

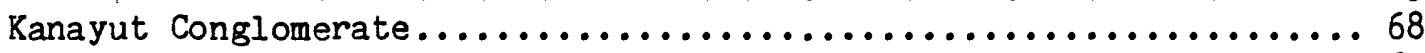

Kayak Shale..........................................69

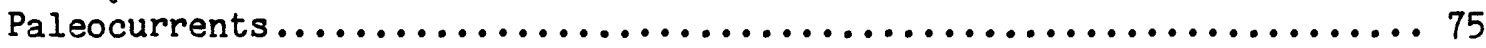

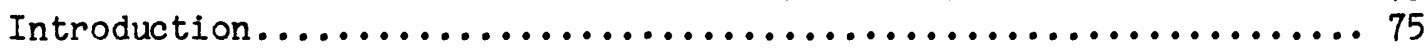

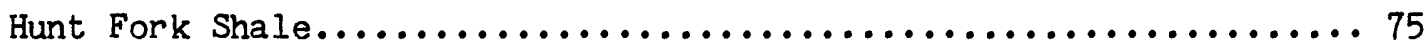

Fluvial members of Kanayut Conglomerate..................... 75

Kayak Shale.......................................... 77

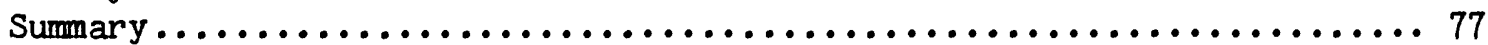

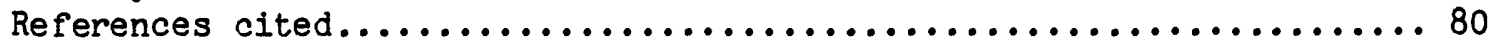




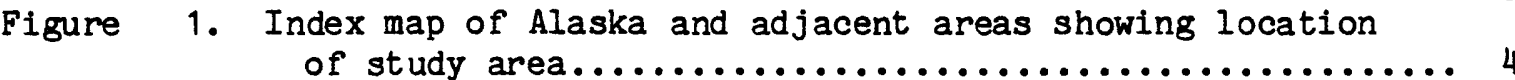

2. Columnar sections and inferred depositional environments of Endicott Group............................ 6

3. Index map of central Brooks range showing distribution of Kanayut Conglomerate and location of measured sections... 14

4. Measured section of the uppermost part of the Hunt Fork Shale and lower shale member of the Kanayut Conglomerate, west side of Atigun River....................... 16

5. Measured section of the middle conglomerate member of the Kanayut Conglomerate, east side of Atigun Creek.........2 24

6. Measured section of the Stuver Member of the Kanayut Conglomerate and Kayak Shale, east side of the Atigun River. 28

7. Measured sections of three correlative fining-upward cycles of the lower shale member of the Kanayut Conglomerate at two locations west of the Itkillik River. 34

8. Measured section of the lower shale member of the Kanayut Conglomerate at Ear Peak, east of Shainin Lake.......... 36

9. Measured section of the middle conglomerate member of the Kanayut Conglomerate south of Shainin Lake............ 40

10. Measured section of the middle conglomerate member of the Kanayut Conglomerate east of the Anaktuvuk River..... 44

11. Measured section of the upper part of the lower shale member, middle conglomerate member, and Stuver Member of the Kanayut Conglomerate west of the John River....... 46

12. Measured section of lower shale member of the Kanayut Conglomerate on the west flank of Mount MacVicar........ 52

13. Measured section of a thick complex cycle in the lowerpart of the lower shale member of the Kanayut Conglomerate east of Okokmilaga River...................... 54

14. Measured section of the Stuver member of the Kanayut Conglomerate, west side of Okokmilaga River........... 56

15. Measured section of the lower shale member and middle conglomerate member of the Kanayut Conglomerate, west side of Killik River.............................62 62

16. Map showing distribution of maximum clast sizes, Kanayut Conglomerate ...............................66 66

17. Contour map showing distribution of maximum clast sizes, Kanayut Conglomerate......................... 67

18. Immature clast--carbonate clast--mature clast ternary diagram from pebble counts made during the 1978, 1979, and 1980 field seasons. A, Basal sandstone member of the Kayak Shale. B, Kanayut Conglomerate............. 71

19. Vein quartz-quartzite-chert ternary diagrams from pebble counts made during the 1978, 1979, and 1980 field seasons. A, Basal sandstone member of the Kayak Shale. B, Kanayut Conglomerate............................... 72 
20. Plots of maximum clast size versus percentage of clast lithology for the Kanayut Conglomerate from pebble counts made during the 1978, 1979, and 1980 field seasons. A, Vein quartz. B, Chert. C, Quartzite.......73

21. Paleocurrent map for the Kanayut Conglomerate........... 76

22. Paleocurrent map for the Hunt Fork Shale and Kayak Shale... 78 
Table

Page

Table 1. Maximum clast size and percentage of each clast type from pebble counts of the Kanayut Conglomerate and basal sandstone member of the Kayak Shale................. 70 


\section{ABSTRACT}

The Upper Devonian Kanayut Conglomerate crops out along the crest of the Brooks Range of northern Alaska for a distance of almost $1000 \mathrm{~km}$. It ranges in thickness from $2600 \mathrm{~m}$ in the Atigun River area to $700 \mathrm{~m}$ south of Anaktuvuk Pass and has been subdivided into four regionally persistent members: (a) the basal sandstone member, consisting of marine sandstone and shale with some conglomerate; (b) the lower shale member, consisting of nonmarine quartzite, conglomerate and shale; (c) the middle conglomerate member, consisting of nonmarine pebble and cobble conglomerate and quartzite; and (d) the Stuver Member, consisting of nonmarine sandstone and shale. The Kanayut conformably overlies the Upper Devonian marine Hunt Fork Shale and is conformably overlain by the Mississippian marine Kayak Shale. The Kanayut is wholly allochthonous and has probably been transported northward on a series of thrust plates.

The basal sandstone member of the Kanayut Conglomerate, which overlies prodelta turbidites of the Hunt Fork Shale, contains marginal-marine coarsening-upward channel-mouth bar sequences. It is conformably overlain by the lower shale member.

Measured sections of the nonmarine members of the Kanayut show that the lower shale member ranges in thickness from $120 \mathrm{~m}$ to $1115 \mathrm{~m}$ and consists of fining-upward cycles interpreted to have been deposited by meandering streams on a broad floodplain. These cycles contain, in ascending order, channelized basal conglomerate, trough cross-stratified sandstone, and ripple-marked siltstone. The cycles are interpreted to be channel and point-bar deposits. Individual cycles average about $10 \mathrm{~m}$ in thickness and are separated by intervals of black, brown or maroon floodplain shale deposits. These typically contain thin coarsening-upward units that probably represent prograding levee sequences and irregular and ungraded sandstone bodies interpreted to be crevasse-splay deposits. In the Okokmilaga River area, the lower shale member contains a distinctive coarse-grained unit which is burrowed and interpreted to represent a widespread marine incursion.

The middle conglomerate member, which ranges in thickness from $155 \mathrm{~m}$ to $525 \mathrm{~m}$, consists of braidplain deposits. It contains fining-upward couplets of conglomerate and parallel-stratified or cross-stratified sandstone that average 2-7 $\mathrm{m}$ in thickness. The couplets record deposition in channels and on bars of braided streams. The middle conglomerate member contains the largest clasts, little or no shale, and represents the maximum progradation of nonmarine sedimentation in the Kanayut depositional system.

The Stuver Member consists of fining-upward cycles that resemble those of the lower shale member. It ranges in thickness from $160 \mathrm{~m}$ to $1400 \mathrm{~m}$ and grades upward into tidal and marginal-marine deposits of the Kayak Shale.

Conglomerate in the Kanayut is compositionally very mature, averaging 82 percent white, gray, black or red chert clasts, 14 percent vein quartz clasts, 3 percent quartzite clasts, and less than 1 percent other lithologies, mainly argillite. Although red chert is locally abundant in the Shainin LakeGalbraith Lake area, there is litte variation in conglomerate composition in the Kanayut, suggesting derivation from a single major source terrane. 
The maximum conglomerate clast size decreases westward, southward and eastward from a maximum of $23 \mathrm{~cm}$ in the Shainin Lake area, suggesting that a major trunk stream originally entered the depositional basin in this area. A second major trunk stream probably entered the depositional basin at its northeastern end.

The orientations of over 600 cross-strata, primary current lineations, current ripple marks, imbrication, and long axes of pebbles in the three fluvial members of the Kanayut consistently show southwesterly-directed sediment transport across most of the central and eastern Brooks Range. The mean and standard deviation of paleocurrent measurements from the lower shale member, the middle conglomerate member and the Stuver Member, respectively, is $243^{\circ} \pm 47^{\circ}, 245^{\circ} \pm 40^{\circ}$ and $234^{\circ} \pm 61^{\circ}$.

The facies sequence in the Hunt Fork Shale, Kanayut Conglomerate, and Kayak Shale suggest that the Kanayut forms the marginal-marine and fluvial parts of a fluvial-dominated deltaic clastic wedge characterized by deposition of coarse-grained sediment. An eastern, northern or northeastern source area for the delta is suggested by the predominance of southwesterly-directed paleocurrents and a southwestward decrease in grain size. Identification of the source area remains difficult because of the allochthonous nature of the Kanayut and its high compositional maturity.

\section{INTRODUCTION}

\section{Purpose and scope}

The Kanayut Conglomerate and associated rocks of the Endicott Group (Tailleur and others, 1967) comprise a depositional complex of Late Devonian and Early Mississippian age in the Brooks Range of northern Alaska (figs. 1 and 2). The Endicott group contains two potential types of clastic reservoir rocks: (1) regionally extensive Upper Devonian strata in the shallow subsurface of the Brooks Range and Southern Foothills, and (2) Lower Mississippian and possibly Devonian strata in isolated basins in the deep subsurface of the Northern Foothills and Coastal Plain. These potential reservoirs underlie parts of the National Petroleum Reserve in Alaska (NPRA).

The Endicott Group consists of two separate sequences, one allochthonous and one autochthonous. The allochthonous sequence consists of a conformable section of the Hunt Fork Shale, Kanayut Conglomerate, and Kayak Shale. This sequence crops out in the central part of the Brooks Range in a series of thrust plates. The autochthonous sequence, consisting of the Kekiktuk Conglomerate and Kayak Shale, rests unconformably on deformed pre-Middle Devonian rocks and granitic plutons of probable Devonian age. This sequence crops out in the northeastern, eastern, and southern Brooks Range around the margins of the allochthonous sequence.

This report presents preliminary results of work completed in 1980 in the central Brooks Range between the Atigun and Killik Rivers (fig. 3). The report also incorporates stratigraphic information obtained by regional mapping in 1975, 1976, and 1977. Stratigraphic and sedimentologic studies of the Kanayut Conglomerate and related units in the central and eastern Brooks 
Range during the 1978 field season have been summarized by Nilsen and others (1980a). That report also contains a summary of the regional lithostratigraphy and biostratigraphy of the Endicott Group, and the reader is referred to that report for stratigraphic background information. Studies of the Kanayut and related units in the eastern and western Brooks Range during the 1979 field season have been summarized by Nilsen and others (1981a).

Four stratigraphic sections were measured in the Endicott Group during the 1978 field season (Nilsen and others, 1980a) and four during the 1979 field season (Nilsen and others, 1981a). In this report, we describe twelve additional measured sections, all from the Kanayut Conglomerate of the central Brooks Range.

\section{Stratigraphy}

The Upper Devonian and Mississippian strata of the Brooks Range were thought to form a major offlap-onlap megacycle in which the Upper Devonian Kanayut Conglomerate and the Lower Mississippian Kekiktuk Conglomerate are the middle nonmarine part of the cycle (fig. 2). The Devonian Hunt Fork Shale comprises the lower marine part of the megacycle and the Mississipian Kayak Shale, or its local equivalent, the Itkilyariak Formation, comprises the upper marine part. The middle Devonian Beaucoup Formation (Dutro and others, 1979) underlies the Hunt Fork Shale and may represent an earlier depositional cycle.

Prior reconnaissance mapping had outlined the distribution of units of the Endicott Group. However, detailed mapping and division of the Kanayut Conglomerate into informal members were limited to areas near Shainin Lake and Anaktuvuk Pass (Bowsher and Dutro, 1957; Porter, 1966). Members of the Kanayut Conglomerate and of the Hunt Fork Shale were mapped in the Philip Smith Mountains quadrangle on the basis of field work done in 1975 and 1976 (Brosge and others, 1979a) and in most of the Chandler Lake and Killik River quadrangles on the basis of field work done in 1977 and 1978 (Brosge and others, 1979b). The mapped boundaries between members, based primarily on the percentage of resistant beds in the respective members, do not, however, necessarily coincide with boundaries determined from the detailed measurement of stratigraphic sections presented in this report.

The Hunt Fork Shale was defined by Chapman and others (1964) in its type area just west of the Okokmilaga Valley. The Kanayut Conglomerate and Kayak Shale were described by Bowsher and Dutro (1957) in the Shainin Lake area and by Porter (1966) near Anaktuvuk Pass. Bowsher and Dutro described and named the upper three members of the Kanayut, and Porter described the lowest member, which is absent at Shainin Lake. All four members were again described, with revised names, in the Philip Smith Mountains area (Brosge and others, 1979a).

The Kekiktuk Conglomerate, named by Brosge and others (1962) for outcrops west of Lake Peters in the northeastern Brooks Range, and the Itkilyariak Formation, named by Mull and Mangus (1972) for outcrops in the Sadlerochit Mountains of the northeastern Brooks Range, form part of the autochthonous sequence of the Endicott Group. These units are not discussed further in this report. 
Figure 1.--Index map of Alaska and adjacent areas showing location of study area. Brooks Range and British Mountains ( $\mathrm{Br}$ ) are outlined in heavy lines. The location of the 1980 field study area is shown by crossed pattern; the 1978 and 1979 field areas by ruled pattern. Abbreviations: AV, Arctic Village; AP, Anaktuvuk Pass; LW, Lisburne Well Site. Quadrangle names are designated by initial letters: $\mathrm{H}$, Howard Pass; K, Killik River; C, Chandler Lake; P, Philip Smith Moutains; A, Arctic; T, Table Mountain; AM, Ambler River; S, Survey Pass; W, Wiseman; $\mathrm{CH}$, Chandalar; CR, Christian; and CO, Coleen. 


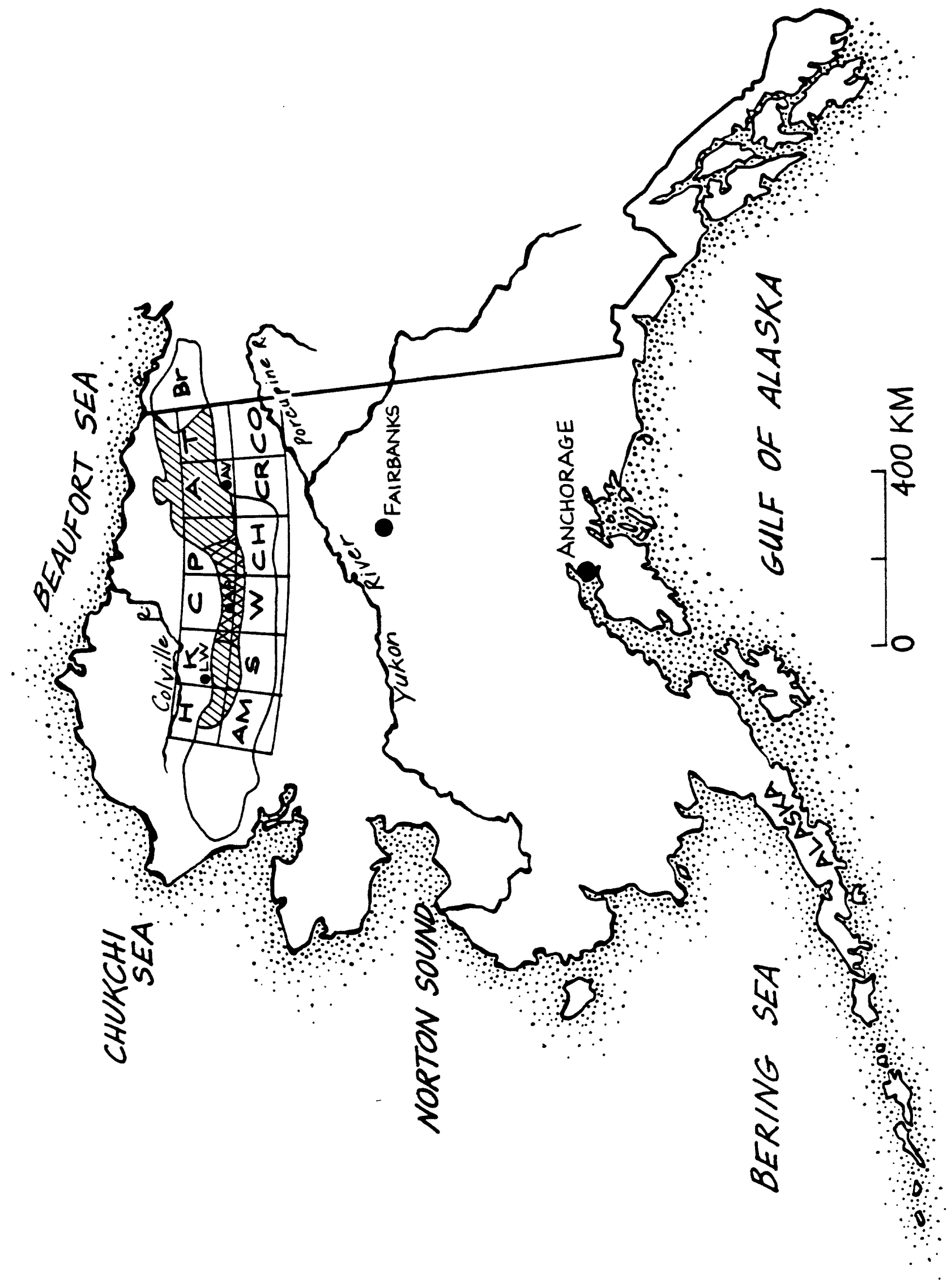




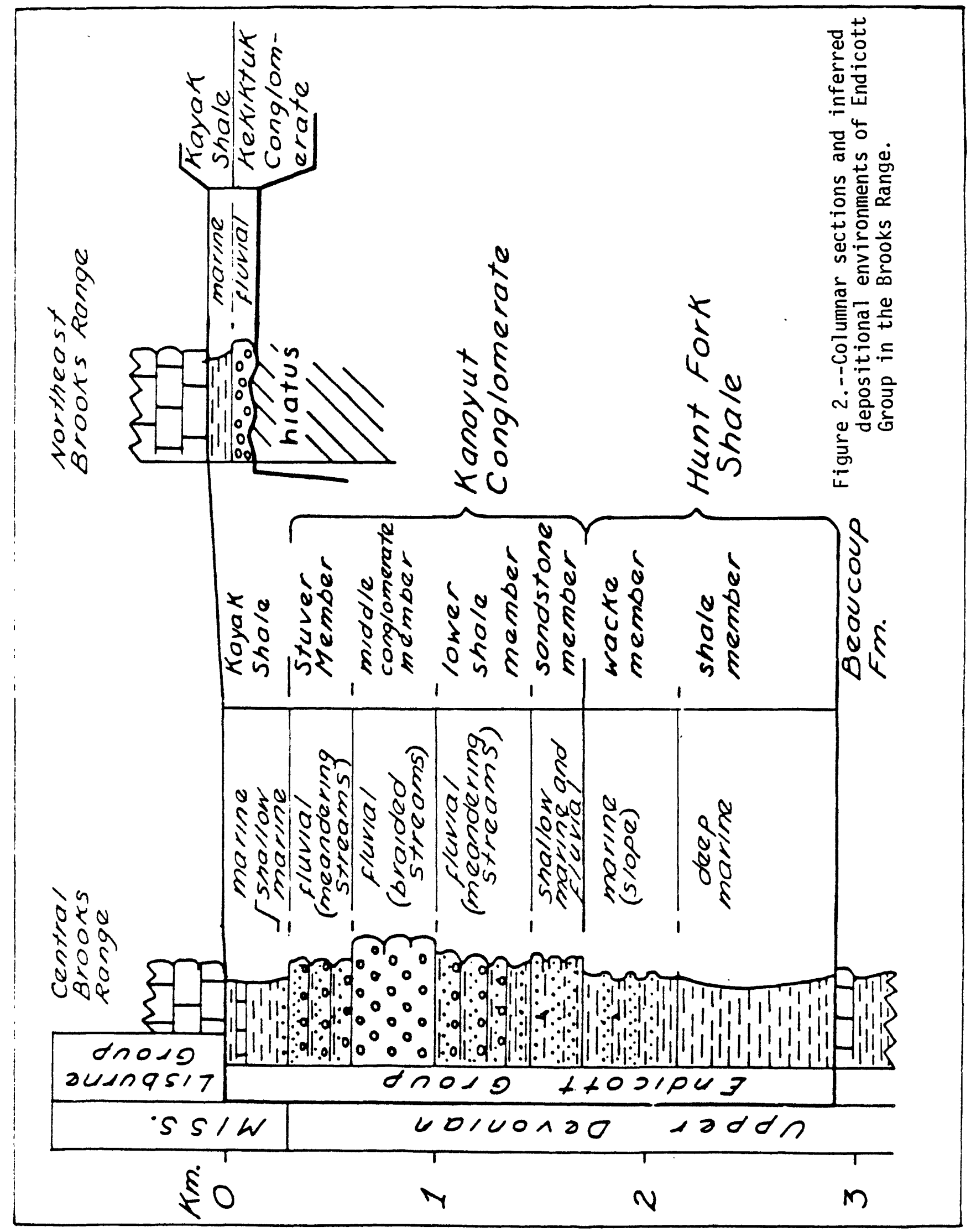


The Upper Devonian Hunt Fork Shale and Kanayut Conglomerate crop out in an east-west-trending belt adjacent to the 68 th parallel and are absent from areas to the north and south, where the Kekiktuk Conglomerate in outcrop rests unconformably primarily on deformed pre-Upper Devonian rocks. Outcrops of the Upper Devonian clastic rocks comprise a series of thrust sheets and are thus allochthonous (Brosge and others, 1979a, b), whereas outcrops of the Kekiktuk rest primarily on deformed basement and are generally thought to be autochthonous or parautochthonous (Nilsen, in press).

The Mississippian Kayak Shale stratigraphically overlies both the Kanayut Conglomerate and the Kekiktuk Conglomerate and is present throughout most of the Brooks Range. In a small area about 50 to $75 \mathrm{~km}$ west-northwest of Arctic Village, both the Kanayut and Kekiktuk are absent and the Kayak Shale rests directly on the Hunt Fork Shale (Nilsen and others, 1981).

Most of the Endicott Group in subsurface is only slightly deformed, whereas all outcropping strata are folded and faulted. The Upper Devonian clastic rocks of the Endicott Group form a series of stacked thrust plates in the central Brooks Range. The Kanayut Conglomerate in the central Brooks Range forms three plates that are bounded by south-dipping thrust faults 125 to $450 \mathrm{~km}$ long and 15 to $30 \mathrm{~km}$ apart, with local displacements of at least 5 to $15 \mathrm{~km}$ (Brosge and others, in press). Westward, the faults obliquely intersect the northern front of the Brooks Range and the thrust plates are folded into west-plunging anticlines that plunge out westward beneath the overlying plate. Eastward, most of the faults also die out within the range into overturned anticlines with little or no horizontal displacement. However, the Toyuk thrust of Porter (1966) extends across most, if not all, of the Kanayut outcrop belt. Because the plates north of the Toyuk thrust plunge out en echelon to the west, the eastern part of the plate overlying the Toyuk thrust forms the south edge of the Kanayut outcrop belt and its western part forms the north edge of the Kanayut outcrop belt at the front of the range.

A set of north-dipping thrust faults separates the Upper Devonian clastic rocks in the central Brooks Range from the southern belt of Kekiktuk Conglomerate outcrops. If these faults are continuous at depth with the faults that bound the Devonian rocks to the north, the entire outcrop belt of the allochthonous Devonian Endicott Group may be a giant klippe (Mull and others, 1976). However, the connection between these faults appears to be buried beneath subsequent thrust plates on the west and has not yet been found where it should be exposed at the east end of the presumed klippe (Brosge and others, in press).

The Upper Devonian part of the Endicott Group is not known for certain to have been reached in the subsurface, but equivalent rocks that have been defined by seismic profiles (Tetra Tech, Inc., 1979) to the northwest may be present locally in the deeper parts of the Umiat and Meade Basins of the western North Slope area. The Endicott Group may be as thick as $2,800 \mathrm{~m}$ in these deeply buried basins because, although seismic interpretations (Tetra Tech, Inc., 1979) indicate a thickness of less than 1,000 m of strata between the base of the Carboniferous Lisburne Group and argillite basement over most of the area, as much as 4,000 $\mathrm{m}$ is present in the Umiat Basin. At the Inigok test well near the edge of the Umiat basin, the Lisburne Group is about 1,200 $\mathrm{m}$ thick, the Kayak Shale $80 \mathrm{~m}$ thick, and the Kekiktuk Conglomerate at least 
$620 \mathrm{~m}$ thick (K. J. Bird and I. L. Tailleur, written communications, 1980). Part of the remaining 2,100 $\mathrm{m}$ of section in the center of the Umiat Basin may consist of Devonian rocks, because it is unlikely that the Kekiktuk attains a thickness of $2,000 \mathrm{~m}$. Steeply dipping conglomerate in Topogoruk Well No. 1 at the northwest edge of the Umiat Basin contains Middle(?) Devonian plant fossils (Collins, 1958). A local basin southeast of the Topogor uk well contains 2,000 $\mathrm{m}$ of stratified Mississippian or younger rocks that, although not yet penetrated by drilling, may be equivalent to the Kanayut Conglomerate (W. P. Brosge, written communication, 1981).

\section{Acknowledgments}

We thank the people of Anaktuvuk Pass for much kindness and assistance. Grant Spearman was especially helpful in facilitating various aspects of our work. Helicopter support by SEAIR, Inc., with Cy Asta, pilot, and Bob Swanson, mechanic, is gratefully acknowledged. Cy Asta helped collect some field data and made important contributions to the project.

\section{SEDIMENTARY FACIES}

\section{General}

The Kanayut Conglomerate and associated units in the Brooks Range contain a variety of sedimentary facies deposited in fluvial and marine environments (fig. 2). The upper part of the Hunt Fork Shale records shoaling marine conditions as it grades upward into the shallow-marine deposits of the basal sandstone member of the Kanayut Conglomerate. The lower shale member of the Kanayut records progradation of fluvial sediments over the basal shallowmarine sandstone, culminating in deposition of the coarser grained fluvial middle conglomerate member of the Kanayut. The successively overlying fluvial Stuver Member, basal shallow-marine sandstone of the Kayak Shale, and shale of the Kayak Shale record major retrogradation of the Kanayut depositional system (fig. 2). Thus, the entire sequence records outbuilding of a major fluvial system, most probably a large delta, out into a marine basin during Late Devonian time.

Earlier eposides of clastic deposition, recorded by conglomerate and sandstone within the Beaucoup Formation and lower Hunt Fork Shale, may or may not be related genetically to the Kanayut onlap-offlap cycle. These less-well understood depositional events may be related more to local uplifts and restricted sedimentation.

\section{Hunt Fork Shale and basal sandstone member of the Kanayut Conglomerate}

Shale deposited in low-energy and probably deep-marine (at least below wave base) settings forms most of the lower part of the Hunt Fork Shale. It is typically black- or brown-weathering and unfossiliferous except for trace fossils. The shale contains thin turbidite interbeds that increase in abundance upward and locally contain fossil debris and shale rip-up clasts. The thin-bedded turbidites form graded beds, generally less than $5 \mathrm{~cm}$ thick, that may contain parallel stratification or current-ripple laminae; however, they are commonly structureless internally, reflecting probable vertical 
settling from storm-generated overflows or interflows within the water column rather than bottom-flowing turbidity currents.

Cycles of shallow-marine sandstone characterize the upper part or wacke member of the Hunt Fork Shale of Brosge and others (1979a, b) and the basal sandstone member of the Kanayut Conglomerate. These sandstone units are locally fossiliferous and contain assemblages characteristic of shelf, intertidal, lagoonal, and marginal-marine environments. The sandstone strata, deposited as a variety of depositional bodies, most typically form thickeningand coarsening-upward cycles, especially in the the basal sandstone member of

the Kanayut Conglomerate. The thickening-upward cycles record progradation of the delta over marine slope and shelf deposits. Although the geometry of these deposits has not been ascertained, the vertical sections resemble those of channel-mouth bars described from many modern deltas.

Other bodies of shallow-marine sandstone, characterized throughout by medium- to large-scale cross-strata that have consistent orientations, may represent offshore bars or spits that formed on the margins of the delta. Variable paleocurrents directions from the shallow-marine sandstone bodies reflect currents generated by waves, winds, tides, and longshore drift.

\section{Kanayut Conglomerate}

The lower shale and Stuver members of the Kanayut Conglomerate are interpreted to have been deposited by meandering streams on a floodplain. The members consist of a series of thinning- and fining-upward cycles similar to those described from many modern meandering rivers. Detailed analysis of the cycles may permit determinations in the future of the sizes of the rivers, their discharges, and temporal or geographical variability of the streams within the depositional basin.

The meandering-stream cycles characteristically commence at their base with erosional truncation of underlying shale or paleosols by thick beds of conglomerate or sandstone. The amount of downcutting observed varies from several cm to as much as $5 \mathrm{~m}$. However, if viewed on a large enough scale, each fluvial cycle probably downcuts approximately the thickness of the individual cycle, inasmuch as the cycle is a preserved record of filling of the individual river channel. The basal beds typically consist of massive or crudely parallel-stratified conglomerate or conglomeratic sandstone containing abundant rip-up clasts of shale, siltstone, and paleosol material.

Overlying the basal conglomeratic beds are parallel-stratified beds of sandstone that are in turn overlain by trough-cross-stratified beds of sandstone. Trough amplitudes gradually decrease upward in the cycles concomitantly with decreasing grain size of the sandstone. The trough axes have variable attitudes, but generally plunge toward the southwest. These deposits represent fill of the channel by transverse and longitudinal bars that migrate downchannel as the stream channel gradually shifts and migrates lateraliy by the meander process.

The upper part of the cycles consists of thinly bedded current-ripplemarked fine-grained sandstone with thin shale interbeds. These ripple-marked sandstones contain abundant mica, clay, and carbonaceous material. Climbing ripples are locally common in these deposits, as well as plant fossils and 
root impressions. These thin beds of sandstone are interpreted to be levees deposited on the inner parts of meander loops by overbanking processes during flood stages.

The uppermost part of the cycles consists of interchannel and floodplain shale and siltstone containing prominent local paleosols. The shale varies from reddish brown to black in color, probably depending upon the amount of exposure to the atmosphere. Red shale probably was deposited chiefly on higher ground of the floodplain and black shale in lower, swampy areas. Many cycles contain red shale directly over the sandy levee facies, succeeded upward by black shale. Both red and black shale contain abundant fossil plant debris, much of it in situ. Mudcracks, raindrop imprints, and features that might represent burrows but are more likely root casts from plants are common. The lower shale member locally contains very thick sections of reddish-brown shale, particularly in the eastern Brooks Range. These deposits may represent large floodplain areas traversed by few river channels. In these areas, shale deposited by major floods probably accumulated to substantial thicknesses.

A characteristic feature of the cycles is long inclined surfaces that cut across the vertical sequence (epsilon cross-stratification). These surfaces are thought to be the original inclined surfaces of the inner parts of meander loops or point-bar surfaces.

Cycles of sandstone not characterized by fining- and thinning-upward trends accumulated in parts of the meandering stream facies. These bodies of sandstone are locally channelized, may form symmetrical vertical cycles, and characteristically contain abundant rip-up clasts and fragments of levee, interchannel, and floodplain facies. The bodies may be crevasse-splay deposits formed where levees have been broken through during large floods.

The middle conglomerate member of the Kanayut Conglomerate consists of interbedded conglomerate and sandstone thought to have been deposited by braided streams. The characteristic feature of these deposits is the vertical stacking of fining-upward couplets of conglomerate and sandstone, with the erosional base of each conglomerate bed truncating the underlying sandstone. In some sections, conglomerate rests on conglomerate to form amalgamated beds, with sandstone absent either as a result of nondeposition or erosion.

The conglomerate-sandstone couplets are thought to represent deposition of various kinds of bars within a braided stream complex. Sandstone is deposited on the flanks, tops, and downstream edges of gravel bars as thin but wide lens-shaped bodies characterized generally by parallel stratification, low-angle trough cross stratification, or very low-angle inclined tabular cross stratification. The sandstone probably accumulates during waning stages of floods and on the protected downstream margins of bars.

The largest conglomerate clasts are found in the middle conglomerate member. The conglomerate is typically well imbricated and characterized by a closed framework with a sandstone or pebbly sandstone matrix. Long axes are oriented parallel to flow and have proven to be useful paleocurrent indicators for the middle conglomerate member. Paleosols, levee deposits, shale, and siltstone are rarely present. 
In its type area, near Shainin Lake, the Kayak Shale is about $300 \mathrm{~m}$ thick, rests conformably on nonmarine facies of the Stuver Member, and has been subdivided into 5 members: 1. basal fine-grained sandstone, $40 \mathrm{~m}$ thick; 2. lower black shale, $180 \mathrm{~m}$ thick; 3. argillaceous limestone, $24 \mathrm{~m}$ thick; 4 . upper black shale, $40 \mathrm{~m}$ thick; and 5. red limestone, $5 \mathrm{~m}$ thick. The three lower members, although their thickness varies, can be traced along the entire Brooks Range, despite marked thickening and thinning of the Kayak as a whole from the effects of thrust faulting. However, in the southern and eastern Brooks Range, the Kayak Shale in the allochthonous sequence of the Endicott Group is generally less than $75 \mathrm{~m}$ thick and consists mostly of black shale.

The basal sandstone member typically consists of thinly cross-stratified and ripple-marked fine-grained quartzose sandstone with abundant Scolithus burrows, a marine ichnofossil. In its type area and elsewhere, it contains both current- and oscillation-ripple markings, reactivation surfaces, flaser bedding, and herringbone cross laminae and cross strata suggestive of tidal current activity. In most localities within the allochthonous sequence of the Endicott Group, the sandstone rests directly on red or black shale or soils of the topmost fining-upward fluvial cycle of the Stuver Member; however, in contrast to coarse-grained deposits of the Kanayut, it consists wholly of fine-grained sandstone, may contain recumbent and syndepositionally folded cross strata, slump folds, ans slurried layers, and may form a thickening- or coarsening-upward megasequence abruptly overlain by black shale of the next member. In a few rare sections, the basal sandstone member forms a very thick cycle of intermixed fine-grained sandstone typical of the basal member and conglomerate of the fluvial Kanayut Conglomerate.

The overlying black shale contains some thin graded beds of fine-grained sandstone that appear to be either turbidites or vertical accumulations of storm-generated sediment overflows. The argillaceous limestone, which appears to form a number of different beds of variable thickness in different areas, contains megafososil debris, including brachiopods, brypzpans, echinoderms, mollusks, and ostracodes. Preliminary examination of these beds suggest a debris-flow origin, because they rest abruptly on and are overlain abruptly by black shale, they are ungraded, have a partly argillaceous matrix, and contain unsorted and chaotic assemblages of calcareous fossil fragments.

The Kayak Shale in general represents a sequence that was deposited in progressively deeper water, except at its top, where it shoals upward into limestone of the Lisburne Group. The basal sandstone represents nearshore, probably tidal sand flat-deposition. Paleocurrent directions from it are highly variable and indicate flow toward the southwest, southeast, and northeast (Nilsen et al., 1980b). The overlying black shale represents deeper marine sedimentation, probably a prodelta slope setting, into which some massive fossiliferous debris flows of argillaceous limestone were resedimented. 


\title{
MEASURED SECTIONS
}

\author{
Atigun Pass area
}

Lower shale member

A section that includes the upper part of the Hunt Fork Shale and the lower shale member of the Kanayut Conglomerate was measured along the west side of the Atigun River Valley, $15 \mathrm{~km}$ south of Galbraith Lake (NW 1/4, T. 13S., R. 12E.), Philip Smith Mountains Quadrangle (fig. 3). The lower part of the section was measured along a small south-flowing tributary creek and the upper part on the shoulder of the ridge located south of the creek. The section is $1412 \mathrm{~m}$ in thickness (fig. 4).

Because the lowermost Kanayut Conglomerate is fine-grained and interdigitates with the Hunt Fork Shale, neither we nor Brosge and others (1979a) recognize here the basal sandstone member of the Kanayut

Conglomerate. We place the contact between the Hunt Fork Shale and the lower shale member of the Kanayut Conglomerate at the first prominent conglomerate and coarse-grained sandstone (at $253 \mathrm{~m}$, fig. 4).

Brosge and others (1979a) mapped the contact between the lower shale member and overlying middle conglomerate member of the Kanayut Conglomerate at the level where conglomerate and resistant sandstone comprise more than 40 percent of the section, probably at $650 \mathrm{~m}$ (fig.4). In contrast, we place the contact higher in the section, where there is an abrupt change from shale-rich fining-upward cycles to conglomerate-sandstone couplets. This yields a lower shale member that is $1160 \mathrm{~m}$ thick (fig. 4).

The lower $252 \mathrm{~m}$ of the section consists of the Hunt Fork Shale. At the base of the section, the Hunt Fork consists of thickening- and coarseningupward cycles of shale, siltstone, and fine- to medium-grained sandstone that contain scattered fragments of plant fossils. The fine-grained parts of the cycles are gray to black, ripple-marked, and contain abundant marine Scolithus-type burrows. The coarse-grained upper parts of the cycles are trough cross-stratified, parallel-stratified, or massive. We interpret these cycles in the Hunt Fork Shale to have been deposited as marine bars in a delta-front to delta-slope setting.

Fining- and thinning-upward fluvial cycles that are intercalated with Scolithus-bearing marine strata appear $100 \mathrm{~m}$ above the base of the section. The fluvial cycles average about $10 \mathrm{~m}$ in thickness and are best developed in the interval between $150-230 \mathrm{~m}$. They typically consist of fine- to mediumgrained sandstone that fines upward to gray to ripple-marked siltstone and shale that are gray to black in color. The basal contact of each cycle is erosive. The sandstone is trough cross-stratified and contains abundant ripup clasts, plant fragments, and rarely, pebbles as large as $2 \mathrm{~cm}$. Large inclined surfaces (epsilon cross stratification) are well developed. Interspersed marine strata may be present at the tops of fining-upward cycles. They consist of burrowed, thinly bedded siltstone and fine- to very fine-grained sandstone that are parallel-stratified, ripple-marked, and lenticular in shape. The marine deposits decrease in thickness and abundance upward to the basal part of the overlying lower shale member of the Kanayut 
Conglomerate. The stratigraphically highest marine strata are $590 \mathrm{~m}$ above the base of the section.

The lowest part of the lower shale member is marked by two prominent fining-upward cycles at $253 \mathrm{~m}$ and $262 \mathrm{~m}$ that contain conglomeratic sandstone at their bases. The cycles near the base of the member, between $253 \mathrm{~m}$ and 405 $m$, typically contain fine- to medium-grained trough cross-stratified sandstone at their base and are overlain by parallel-stratified, very fine-grained sandstone, siltstone and shale. The fine-grained tops of some cycles are thin and contain Scolithus-type burrows, indicating a marine origin. Two cycles between $300 \mathrm{~m}$ and $380 \mathrm{~m}$ contain thick accumulations of interstratified ripplemarked fine-grained sandstone and shale that lack burrows and may represent either fluvial floodplain or freshwater lake deposits. We infer that these these interbedded marine and fluvial strata near the Hunt Fork-Kanayut contact record a gradual progradation of coarse-grained delta-plain meandering streams over fine-grained delta-front sediments. The complex interfingering probably reflects vertical and lateral accretion of meandering-fluvial-channel, interdistributary-bay, brackish-swamp, low-energy-shoreline, and freshwater lake deposits.

The middle and upper parts of the lower shale member above $405 \mathrm{~m}$ consist of thinning- and fining-upward cycles inferred to be meandering river deposits. These cycles contain both coarser-grained deposits than those at the base of the member and thicker basal sandstone and conglomerate units that exhibit multiple scour horizons and local trough cross-stratification. The coarse basal facies of each cycle probably represent channel and lower pointbar deposits. The basal deposits are typically overlain by trough crossstratified, fine- to medium-grained sandstone capped by red, maroon, or black siltstone and shale. These fine-grained sediments were probably deposited on the upper surfaces of point-bars, levees, and floodplains. Shale and siltstone intervals are thin or nonexistent in the middle of the lower shale member between $720 \mathrm{~m}$ and $890 \mathrm{~m}$, but increase in thickness upward toward the top of the section. Near the top, the floodplain deposits are as thick as 20 $m$ and commonly rest directly on conglomeratic strata without intervening sandstone of substantial thickness. One well-exposed floodplain sequence near the top, between $1350 \mathrm{~m}$ and $1365 \mathrm{~m}$, contains two cycles of black shale, thin rippled-marked sandstone, and a paleosol. These thin coarsening-upward cycles are 2-3 $\mathrm{m}$ in thickness and probably record outbuilding of levees into adjacent swampy lowlands or lakes on the floodplains.

The contact with the overlying middle conglomerate member at the top of the section is abrupt and marked by the disappearance of shale and appearance of massive sandstone and conglomeratic strata. This contact reflects the influx of coarser-grained sediment and transition to deposition by braided streams.

Cycles are generally thicker at the base of the lower shale member, thinnest in the middle part, and thickest at the top. The cycles average 20$30 \mathrm{~m}$ in thickness at the base of the member, $10-20 \mathrm{~m}$ in the middle, and $45 \mathrm{~m}$ at the top.

Clast size increases regularly upward. In the Hunt Fork Shale and at the base of the lower shale member, conglomerate is rare and the maximum clast size is $2 \mathrm{~cm}$. At the top of the lower shale member, the maximum clast size is 
Figure 3.--Index map of central Brooks Range showing distribution of Kanayut Conglomerate and location of measured sections. Sections: 1, Upper Hunt Fork Shale and lower shale member of the Kanayut Conglomerate, Atigun River. 2, Middle conglomerate member, Atigun River. 3, Stuver Member, Atigun River. 4, Lower shale member, Itkillik River. 5, Lower shale member, Ear Peak. 6, Middle conglomerate member, south of Shainin Lake. 7, Middle conglomerate member, Anaktuvuk River. 8, Upper part of lower shale member, middle conglomerate member, and Stuver Member, John River. 9, Lower shale member, Mount MacVicar. 10, Stuver Member, Okokmilaga River. 11, Thick cycle in lower part of lower shale member, Okokmilaga River. 12, Lower shale member and middle conglomerate member, Killik River. 


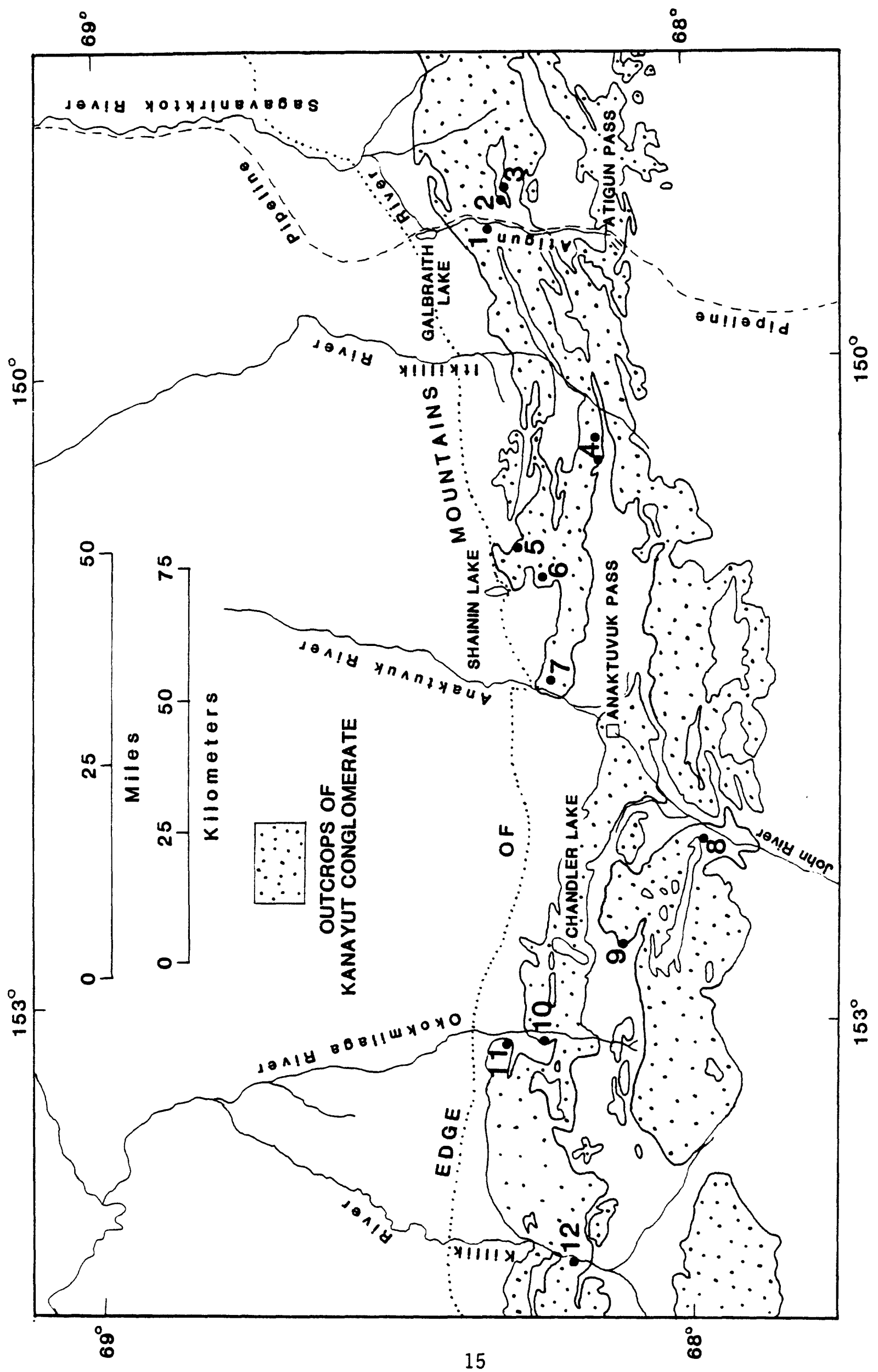


Figure 4.--Measured section of the uppermost part of Hunt Fork Shale and lower shale member of the Kanayut Conglomerate, west side of Atigun River. See Figure 3 for location of section. 


\section{SYMBOLS}

for figures 4 to 15
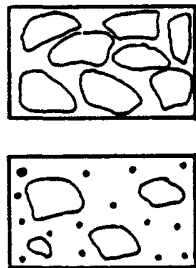

Conglomeratic sandstone
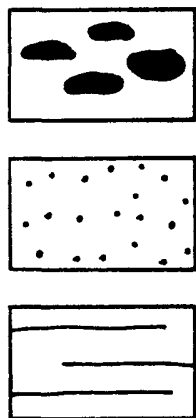

Sandstone, parallel-stratified
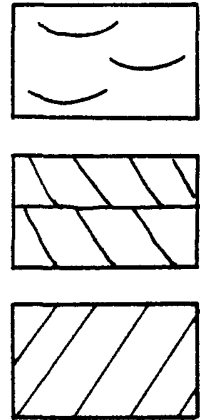

Epsilon cross-stratification

Sandstone, trough cross-stratified

Sandstone, tabular cross-stratified
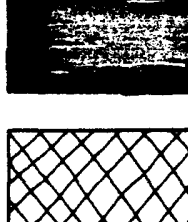

Coal

Siltstone and shale

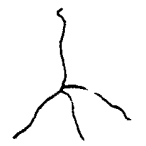

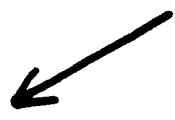
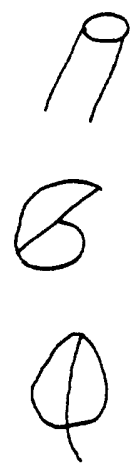

Float lithology

Fining-upward cycle

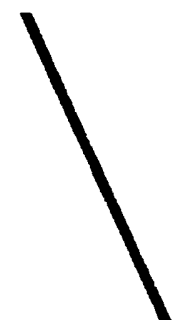

Coarsening-upward cycle

Paleocurrent azimuth

Burrow, invertebrate

Invertebrate fossil

Root cast

$\nabla \nabla \nabla \quad$ Mudcracks

$D$ syndepositional shump fold 


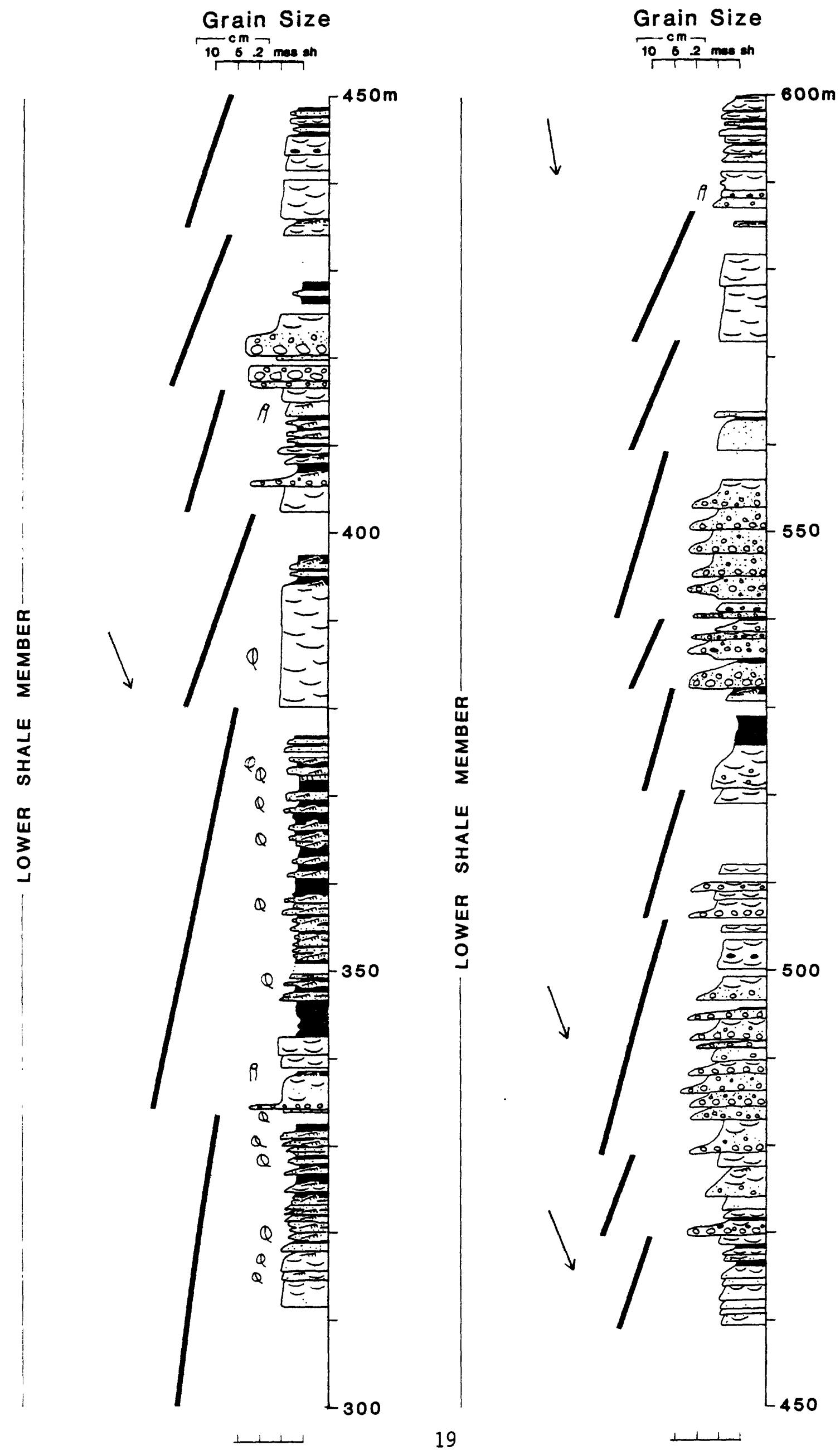




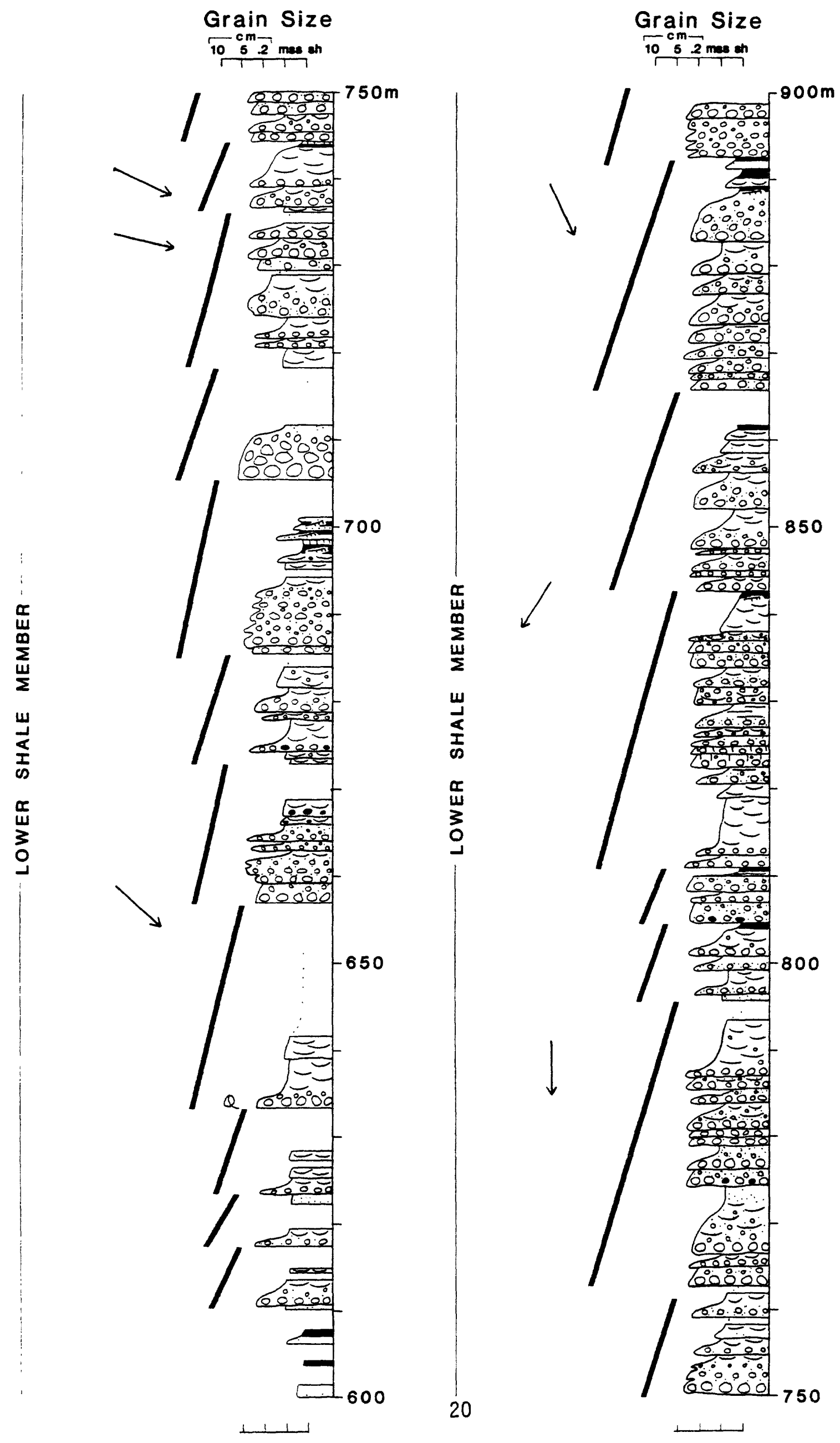




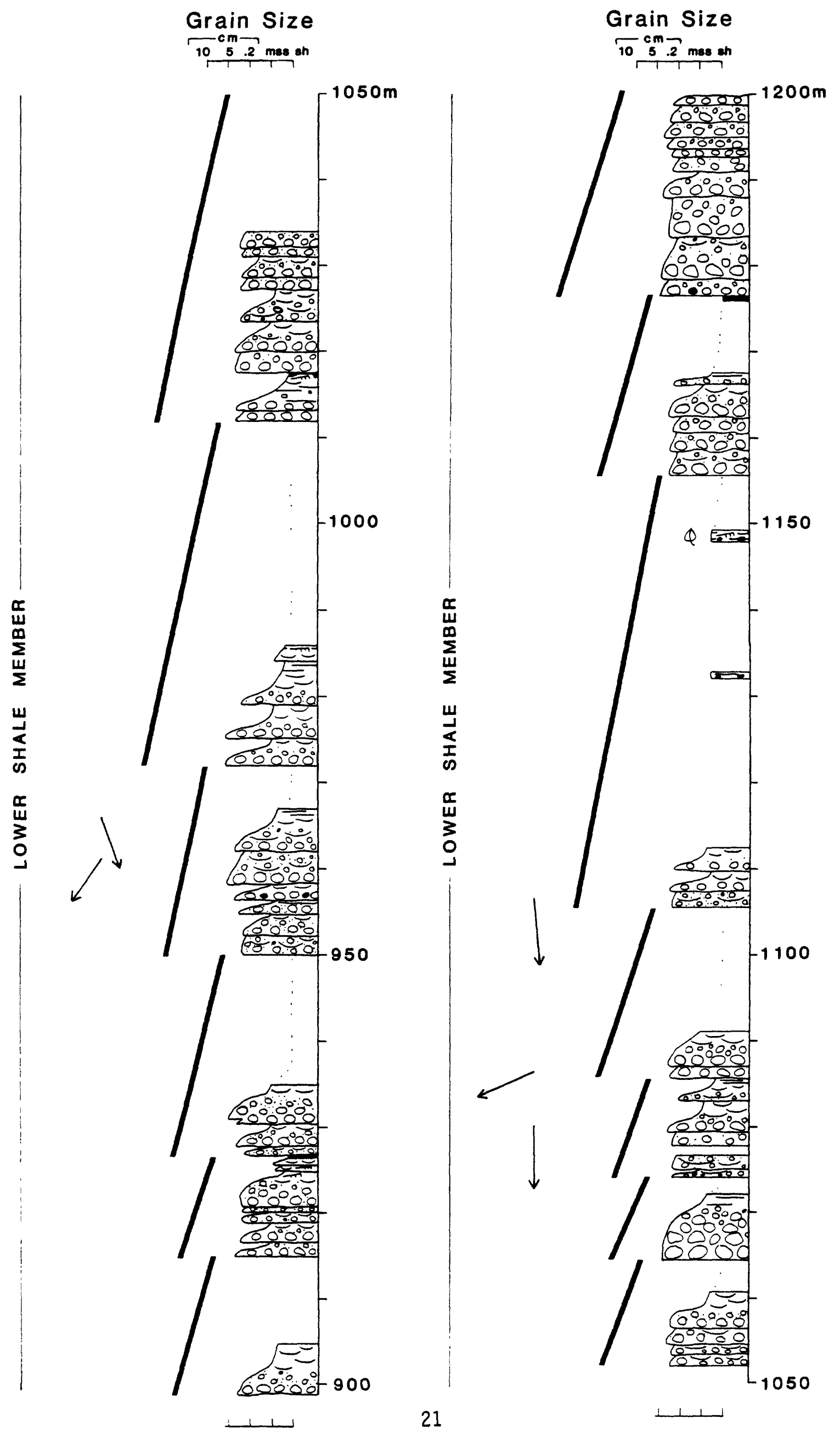


Grain Size

$10 \stackrel{\mathrm{cm}}{5} .2 \mathrm{mss} s \mathrm{~h}$

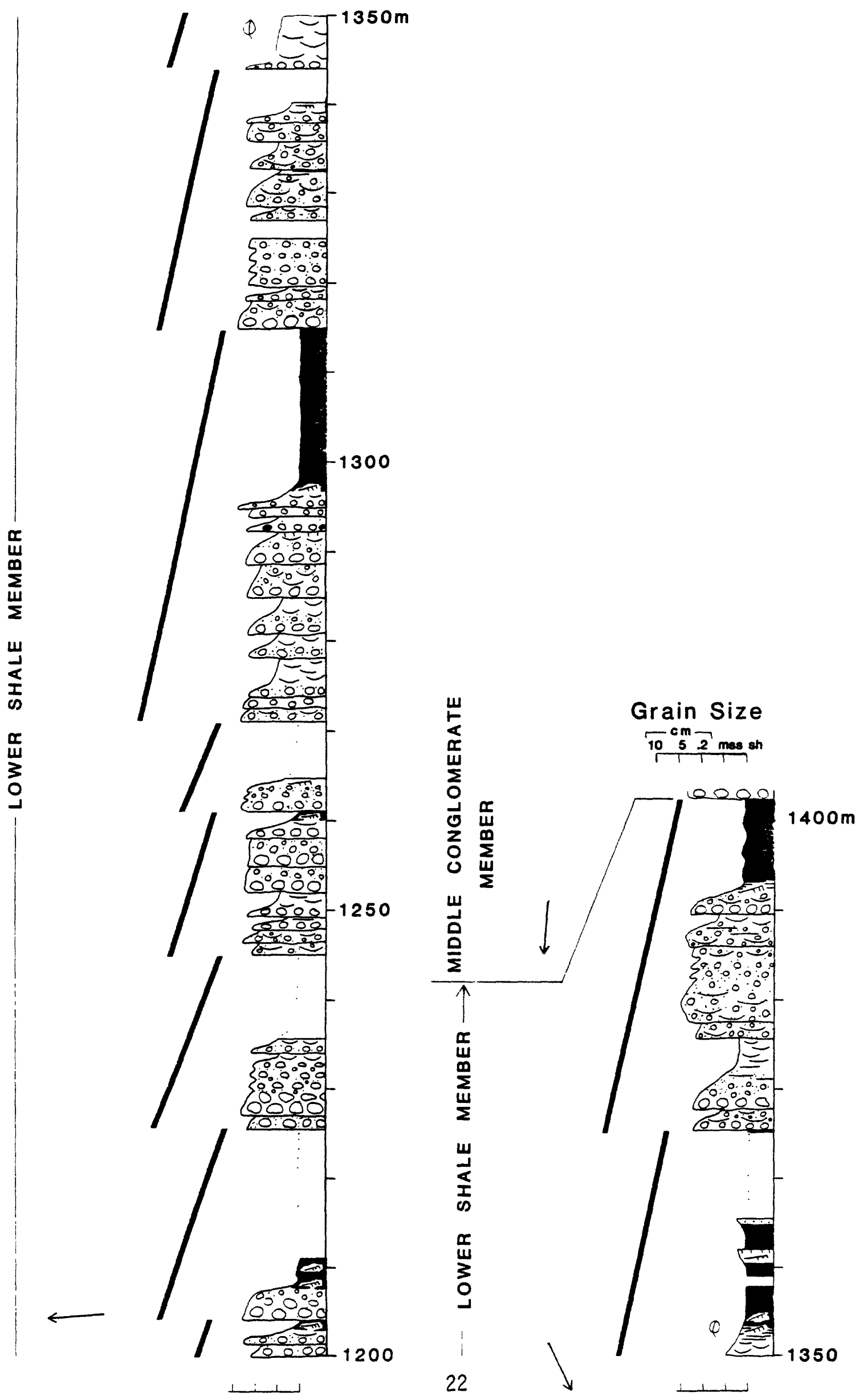


$5 \mathrm{~cm}$. Two pebble counts from the lower shale member show that the clast composition is typical of the Kanayut, averaging 85 percent chert and 15 percent vein quartz. Quartzite is absent and red chert comprises 2 percent of the conglomerate clasts.

Paleocurrent measurements from the section are consistent in orientation and indicate southward sediment transport. There is little difference between directions from the Hunt Fork Shale and the lower shale member of the Kanayut Conglomerate. The mean and standard deviation of 8 measurements from the Hunt Fork Shale are $186^{\circ} \pm 21^{\circ}$ and of 17 measurements from the lower shale member are $171^{\circ} \pm 38^{\circ} \mathrm{p}$.

Middle conglomerate member

A complete section of the middle conglomerate member of the Kanayut Conglomerate was measured on a steep east-facing valley wall approximately 15 km southeast of Galbraith Lake, (NE 1/4, T.13S., R.12E., Philip Smith Mountains Quadrangle). The measured section ( $\mathrm{fig}$. 5) is very well exposed along a small northeast-trending creek. The middle conglomerate member at this location is $155 \mathrm{~m}$ thick and is conformably underlain and overlain by the lower shale and Stuver members, respectively. The contacts between the members are abrupt and marked by the absence of shale in the middle conglomerate member. The basal $12 \mathrm{~m}$ ( 1 cycle) of the Stuver Member were also measured at this location, resulting in a total thickness of $167 \mathrm{~m}$ for the entire section. The middle conglomerate member at this location was previously mapped by Brosge and others (1979a) as the massive marker bed within a thicker and lithologically more variable middle conglomerate member.

The measured section consists almost exclusively of interstratified conglomerate, conglomeratic sandstone, and coarse-grained sandstone. Finegrained sandstone, siltstone and shale are present only in the basal part of the Stuver Member at the top of the section. Beds of conglomerate are lenticular, as thick as $7.3 \mathrm{~m}$, and contain clasts clasts as large as $10 \mathrm{~cm}$. Beds of sandstone are as thick as $1.4 \mathrm{~m}$ and are commonly conglomeratic, containing pebbles as large as $3 \mathrm{~cm}$.

The conglomerate and sandstone beds form fining-upward couplets in which the conglomeratic base of each couplet is channeled into the underlying sandstone or conglomeratic sandstone. The conglomerate is clast-supported, typically massive to crudely parallel-stratified, and has a well-defined fabric characterized by upstream dip of imbricated pebbles and orientation of long axes parallel to flow. The matrix consists of sandstone and finer conglomeratic sandstone. Beds of sandstone are generally parallel-stratified to trough cross-stratified but are locally massive. They form thin, flat lenses in outcrops that are truncated above by beds of conglomerate. In the interval between $100 \mathrm{~m}$ and $150 \mathrm{~m}$ above the base of the section, conglomerate beds are commonly overlain by a scoured surface and another conglomerate bed, resulting in a sequence of amalgamated conglomerate. This interval contains the coarsest conglomerate. The section above $150 \mathrm{~m}$ changes abruptly in character. Two fining- and thinning-upward cycles can be recognized, although partly covered, by the fine-grained sandstone, siltstone, and shale which is present in both float and outcrop in their upper parts. The overlying conglomerate is scoured into these fine-grained deposits and locally contains well-developed flute casts at its base. 


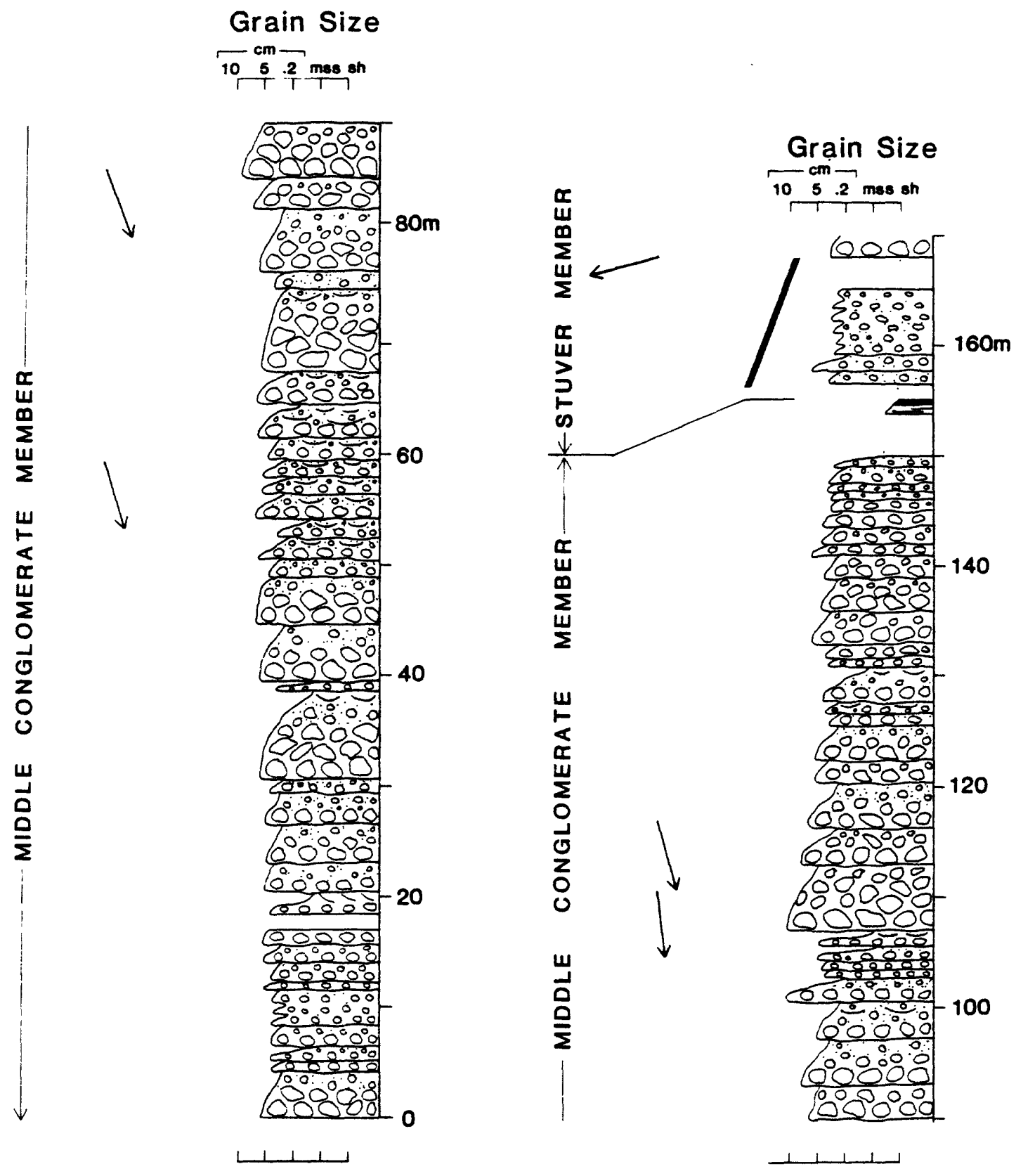

Figure 5.--Measured section of the middle conglomerate member of the Kanayut Conglomerate, east side of Atigun River. See Figure 3 for location of section. 
The lower $155 \mathrm{~m}$ of the section was probably deposited by braided streams. Fining-upward conglomerate-sandstone couplets probably were formed by lateral and vertical accretion of migrating longitudinal bars. Migrating dunes and sandwaves superimposed on larger bars resulted in crossbedded sandstone. The transition to the thicker fining-upward cycles of the Stuver Member, which include siltstone and shale in their upper parts, may mark a change to deposition by a meandering river system. The coarse basal parts of these thicker cycles are interpreted to be river-channel and point-bar deposits, and the upper fine-grained strata upper-point-bar, levee, and floodplain deposits.

Two pebble counts indicate an average composition of 88 percent chert, 11 percent vein quartz, and 1 percent quartzite. Red chert clasts are notably abundant, composing approximately 40 percent of the total number of clasts.

Four paleocurrent measurements of trough cross-strata axes, clast imbrication, and clast long axes indicate that sediment transport was consistently southward during deposition of the middle conglomerate member. Flute casts at the top of the section are oriented toward the west, however, possibly suggesting a change to more westerly sediment transport during deposition of the basal strata of the Stuver Member. The mean and standard deviation for all seven paleocurrent measurements from this section are $1880 \pm 43^{\circ}$.

\section{$\underline{\text { Stuver Member }}$}

A thick section of the Stuver Member of the Kanayut Conglomerate was measured on a north-trending ridge about $6 \mathrm{~km}$ east of the Atigun River Valley (sec. 13, T.13S., R.13E., Philip Smith Mountains Quadrangle). Contacts with the underlying middle conglomerate member and overlying Kayak Shale are well exposed (Fig. 6).

Nearly 1,300 $\mathrm{m}$ of section were measured within the Stuver Member, with less than 1 percent covered. The contact with the middle conglomerate member is marked by the termination of massive conglomerate beds and beginning of distinct fining-upward cycles that contain shale intervals that are 1 to $2 \mathrm{~m}$ thick at the base of the Stuver Member. The cycles commence with beds of conglomerate or conglomeratic sandstone that have a maximum clast size of 7 $\mathrm{cm}$, compared to $8.5 \mathrm{~cm}$ at the top of the middle conglomerate member. These generally massive beds have an erosional contact with underlying strata and may contain shale rip-up clasts as large as $1 \mathrm{~m}$. The coarse-grained beds grade upward into trough-cross-stratified and current-rippled-marked sandstone that is overlain by extensive sequences of interbedded shale, siltstone, and very fine-grained sandstone as thick as $55 \mathrm{~m}$.

The fining-upward cycles and the overall fining-upward pattern of the Stuver Member are indicative of meandering stream deposits and gradual retrogradation of the Kanayut delta. The conglomerate and conglomeratic sandstone at the base of the cycles represent channel deposits, grading upward into point-bar deposits represented by the trough-cross-stratified and ripplemarked sandstone. Floodplain, crevasse-splay, and levee deposits are represented by the thick sequences of shale, siltstone, and fine-grained sandstone at the tops of the cycles. 
The fine-grained floodplain deposits form distinctive units within the section. Within the overall fining-upward cycles, they contain distinct coarsening-upward sequences that average $1 \mathrm{~m}$ in thickness. Some beds have abrupt contacts with overlying and underlying units. Sandstone within the fine-grained deposits may be rippled, laminated, or massive and laterally discontinuous. Colors of the beds include red, orange, green, brown, and black, probably depending on the degree of oxidation of the sediments. Plant fragments, root traces, and some rip-up clasts are present in these deposits, with mudcracks and paleosols developed in many horizons.

As the base of the Kayak Shale is approached, the Stuver Member contains evidence of alternating marine and fluvial environments. Couplets of gray very fine- to medium-grained sandstone capped by oscillation ripple marks probably represent limited marine wave activity. The contact with the overlying basal shallow-marine sandstone of the Kayak Shale is marked by the appearance of thoroughly bioturbated zones and abundant oscillation ripple markings. The presence of distinct fining-upward cycles interpreted to be fluvial in origin permits subdivision of the 64-m-thick basal sandstone of the Kayak into 3 separate fluvial and marine cycles. The black shale of the Kayak that overlies the basal sandstone is platy, with a few thin sandstone interbeds which may be turbidites. Crinoidal debris, corals, and brachiopods are present within the lowermost bed of the limestone over the shale.

Conglomerate clasts within a sandstone bed at $1280 \mathrm{~m}$, approximately $30 \mathrm{~m}$ below the base of the Kayak Shale, consist of 82 percent chert, 17 percent vein quartz, and 1 percent quartzite. Conglomerate clasts in the basal sandstone of the Kayak Shale consist of 83 percent chert, 15 percent vein quartz, and 2 percent quartzite in one area and 83 percent chert and 17 percent vein quartz in a second area. Clasts range in size from $7 \mathrm{~cm}$ at the base of the Stuver Member to $1 \mathrm{~cm}$ near the contact with the Kayak Shale.

Forty-six paleocurrent measurements from the Stuver Member at this location have a vector mean and standard deviation of $203+450$. Sedimentary features measured include trough cross-strata ( 22 measurements), primary current lineation ( 9 measurements), clast long-axis orientations and current ripple markings ( 5 measurements each), erosional scours (2 measurements), and flute casts ( 1 measurement). One measurement of clast imbrication and longaxis orientation was determined for the Kayak Shale, yielding a sediment transport direction of $170^{\circ}$.

ITKILLIK RIVER AREA

Lower shale member

Two short measured sections of three correlative fining-upward cycles within the lower shale member of the Kanayut Conglomerate were measured along the south flank of an east west-trending ridge west of the Itkillik River in the Chandler Lake Quadrangle. Section A was measured in section 6, T.15S., R.8E., about $4 \mathrm{~km}$ east of section B, measured in section 3, T.15S., R.8E. (fig. 7). The purpose of the measured sections was to examine lateral changes in individual beds and cycles of the Kanayut in an area where individual cycles could be easily traced laterally. We had intended to measure the three 
cycles at additional places on the east-west trending ridge, but bad weather permitted us time to measure only sections $A$ and $B$.

Section $\mathrm{A}$ is about $36 \mathrm{~m}$ thick and contains three major individualiy distinctive major fining-upward cycles. The lower cycle, about $13 \mathrm{~m}$ thick, is most clearly fining- and thinning-upward in character. It contains about $7 \mathrm{~m}$ of conglomerate and sandstone with a maximum clast size of $3 \mathrm{~cm}$ in its lower part and $6 \mathrm{~m}$ of maroon and black shale in its upper part. Two prominent beds of fine-grained sandstone are present in the floodplain deposits and probably represent crevasse-splay deposits.

The middle cycle of section $A$, about $11 \mathrm{~m}$ thick, contains a thick basal amalgamated bed of conglomerate that is about $2 \mathrm{~m}$ thick and has a maximum clast size of $2 \mathrm{~cm}$. The bed coarsens upward in its lower $30 \mathrm{~cm}$ and then fines abruptly upward into $8 \mathrm{~m}$ of maroon and black shale that contains three thin ripple-marked and laminated beds of very fine-grained sandstone.

The upper cycle of section $\mathrm{A}$ is about $12 \mathrm{~m}$ thick and more complex in its internal organization. It coarsens upward over a $5 \mathrm{~m}$ thickness before abruptly fining upward to red shale and green siltstone. The maximum clast size is $3.5 \mathrm{~cm}$ in the lower thinner beds of conglomerate and $4 \mathrm{~cm}$ in the upper thicker bed. The floodplain sequence consists of only $1.5 \mathrm{~m}$ of shale.

Westerly transport of sediments is suggested on the basis of two paleocurrent measurements from the lower cycle, none from the middle cycle three from the upper cycle, and one from the overlying cycle (fig. 7). The measurements include three trough-cross strata, two clast imbrication and long-axis orientations, and one flute cast.

Section $B$ is about $52 \mathrm{~m}$ thick and contains what we believe are the same three fining- and thinning-upward cycles. The cycles are relatively similar in character, with the lower cycle having the most clearly developed finingupward character, the middle cycle being the thinnest and consisting mostly of a single coarse-grained bed, and the uppermost cycle being most complex, characterized in part by a coarsening- and thickening-upward character of the conglomeratic part of the cycle. No paleocurrents were obtained from the cycles in section $B$.

The lower cycle of section $B$ is about $26 \mathrm{~m}$ thick and has a maximum clast size of $9 \mathrm{~cm}$. It consists of a lower $10 \mathrm{~m}$ of conglomerate and sandstone and an overlying $16 \mathrm{~m}$ of maroon shale that contains three prominent interbeds of sandstone and soil horizons. The lower interbedded unit, about $12 \mathrm{~m}$ above the base of the section, consists of trough-cross-stratified, fine- to mediumgrained sandstone and may be a crevasse-splay deposit. The two upper interbeds consist of fine-grained sandstone and an orange paleosol.

The middle cycle of section $B$ is about $12 \mathrm{~m}$ thick. It consists of a basal medium-grained sandstone that coarsens upward to conglomeratic sandstone with a maximum clast size of $0.5 \mathrm{~cm}$. The coarse-grained basal part of the cycle is about $2 \mathrm{~m}$ thick. The overlying maroon shale floodplain sequence is about $10 \mathrm{~m}$ thick, and contains several soil horizons and thin interbedded units of fine-grained, ripple-marked sandstone. 
Figure 6.--Measured section of the Stuver Member of the Kanayut Conglomerate and Kayak Shale, east side of Atigun River. See Figure 3 for location of section. 


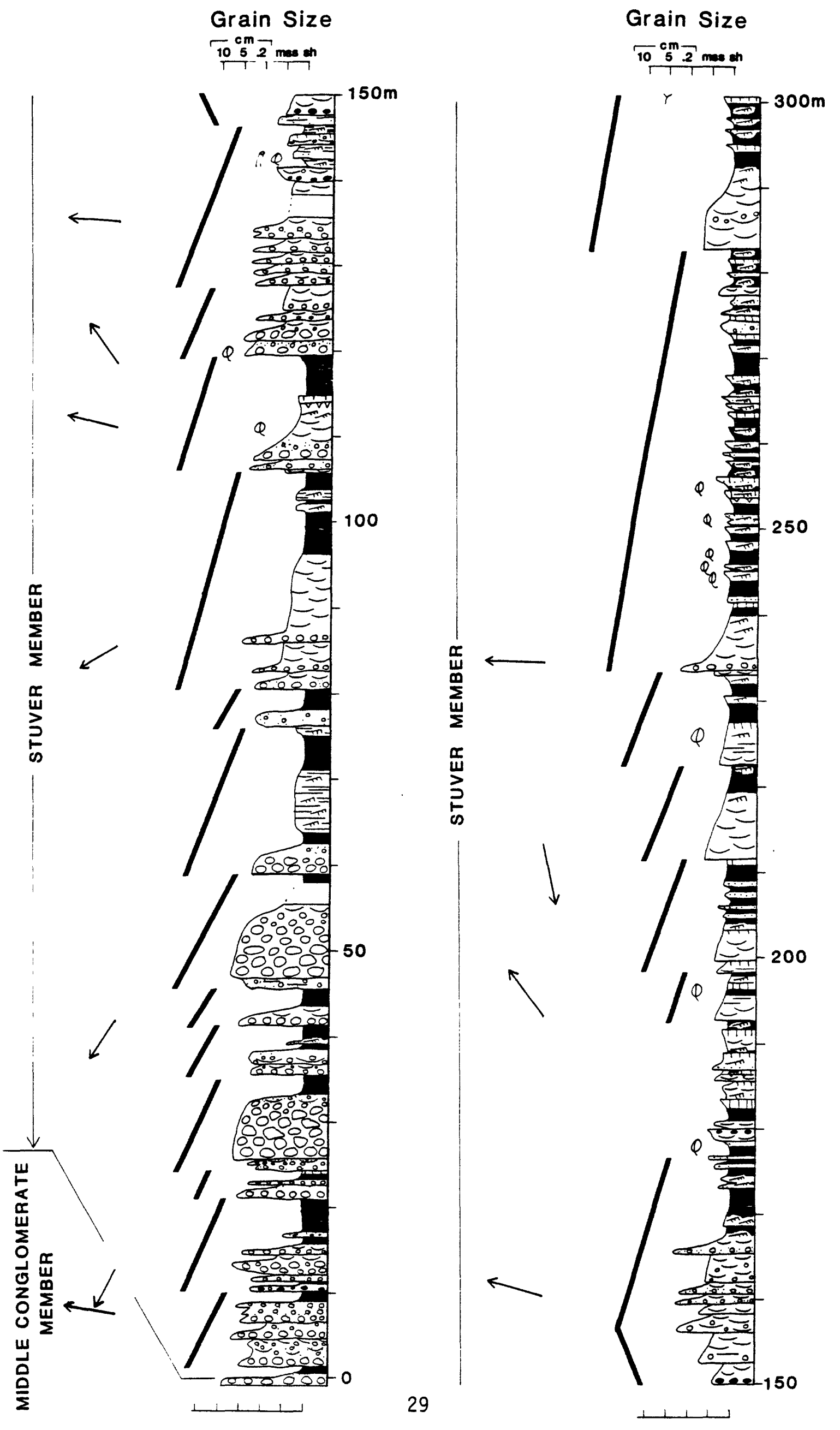


Grain Size

$70 \mathrm{~cm} 2 \mathrm{mes} \mathrm{sh}$

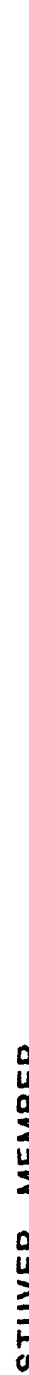

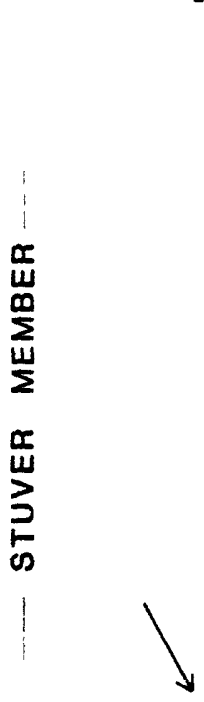
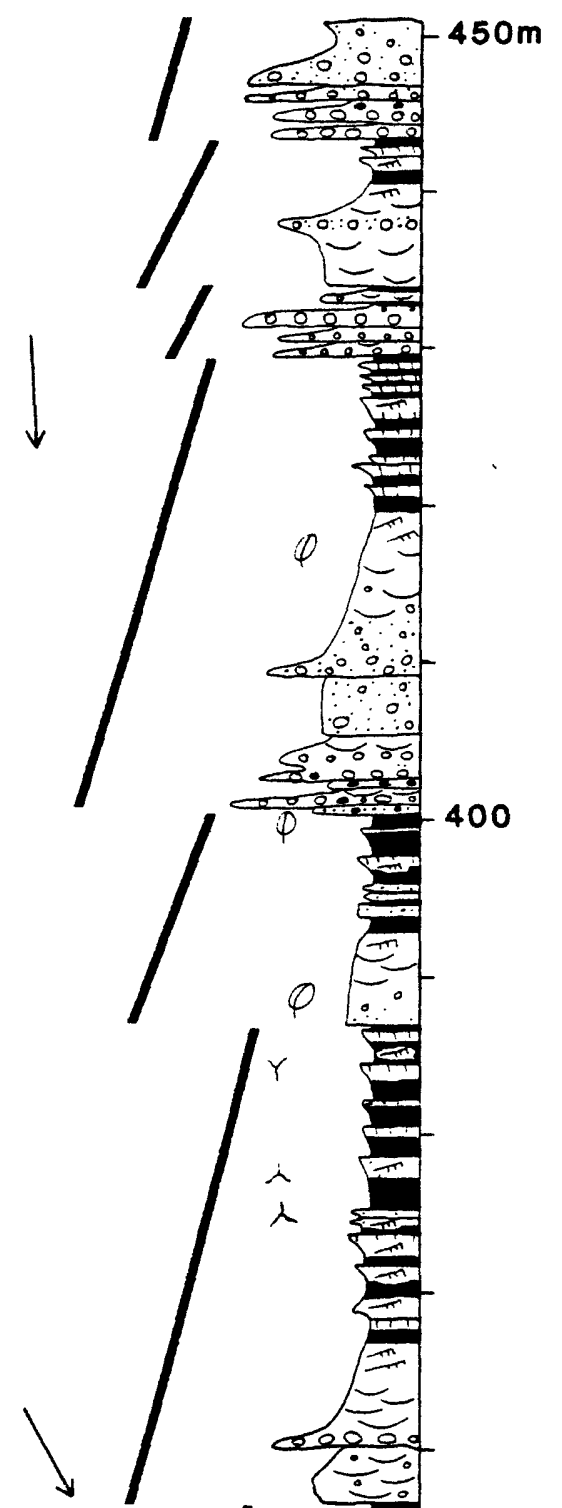

$\downarrow$
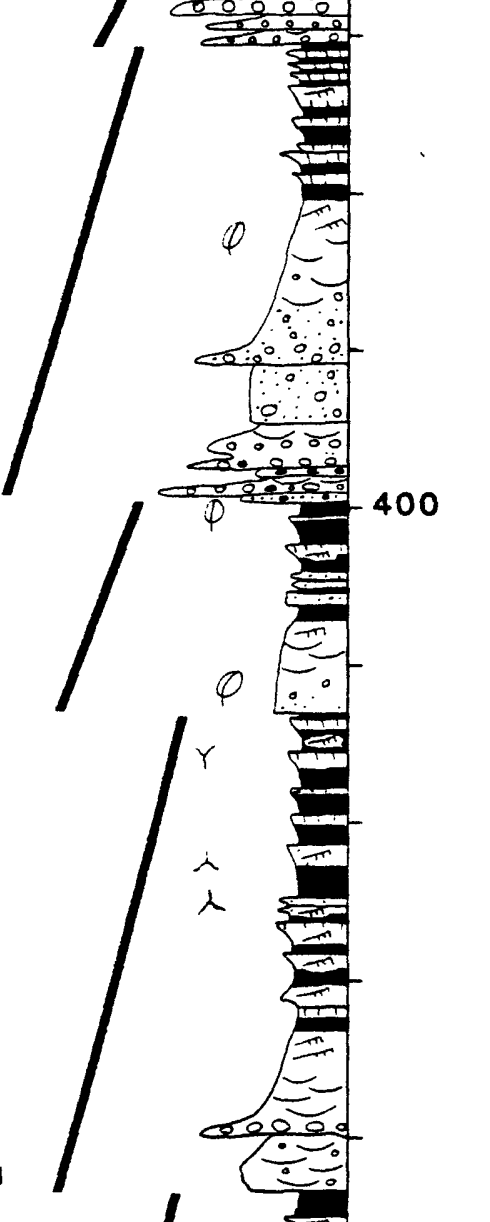

$-350$

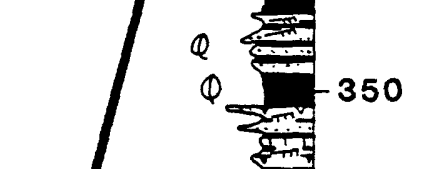

Grain Size

$10 \mathrm{~cm} 2 \mathrm{mmas}$
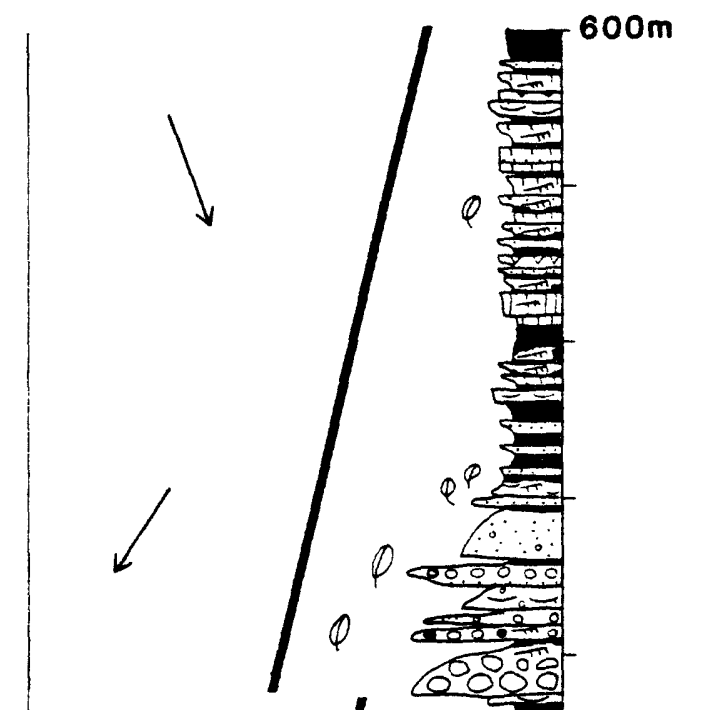

$\mid$

$\mid$
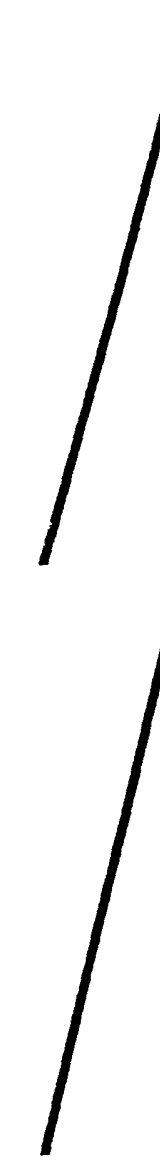

450 


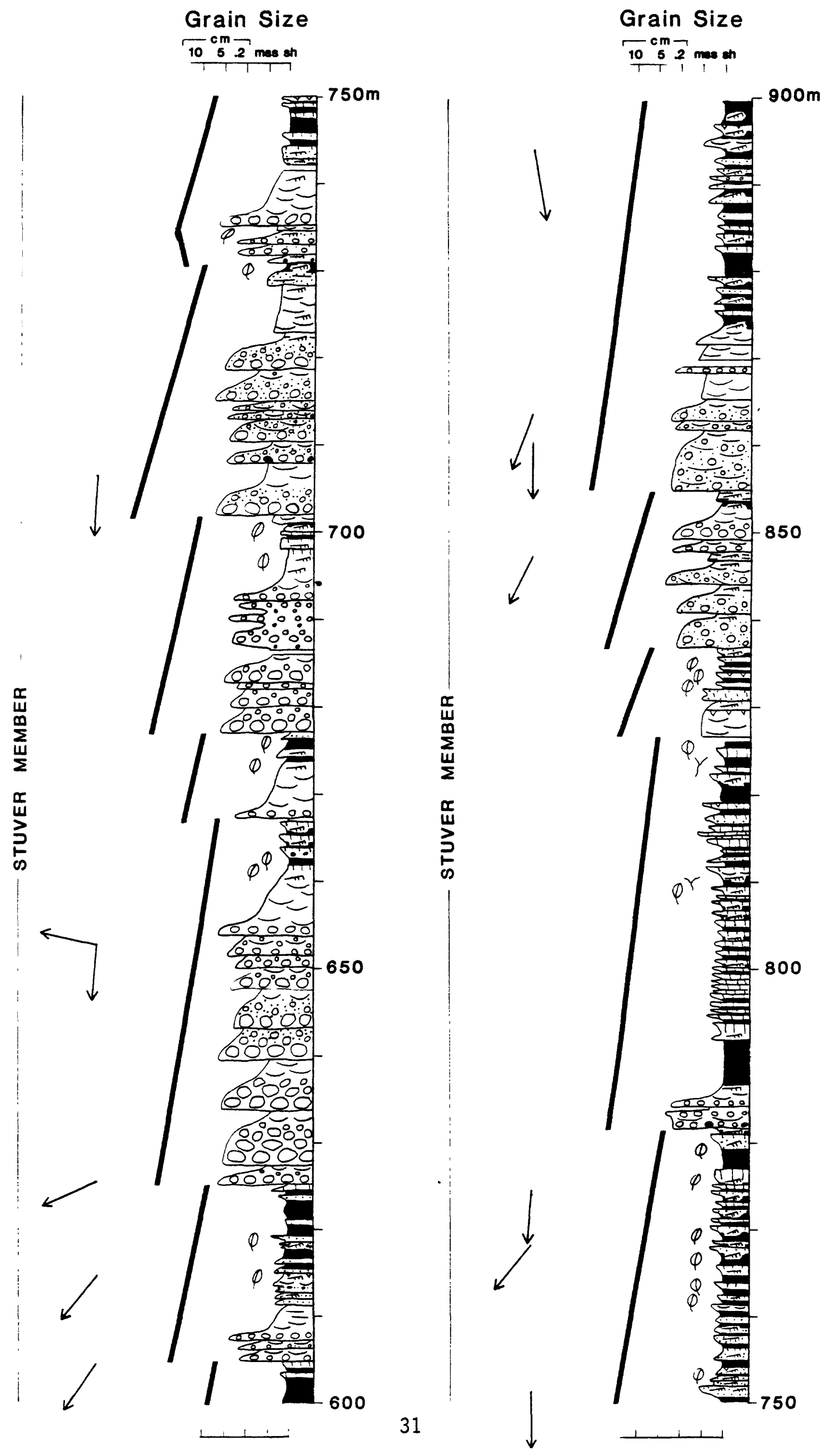


Grain Size

$70{ }_{5} .2$ mas an

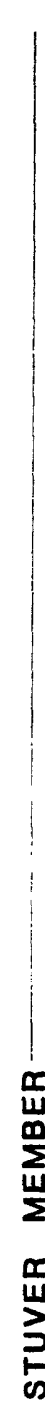

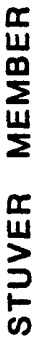

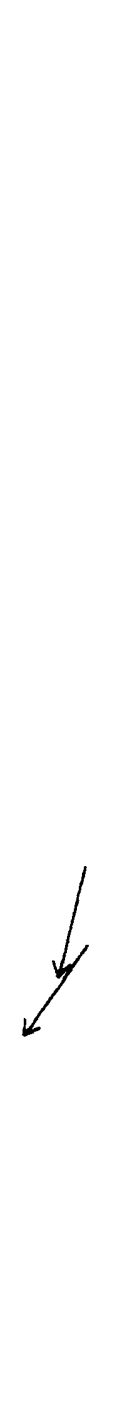

$\downarrow$

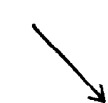

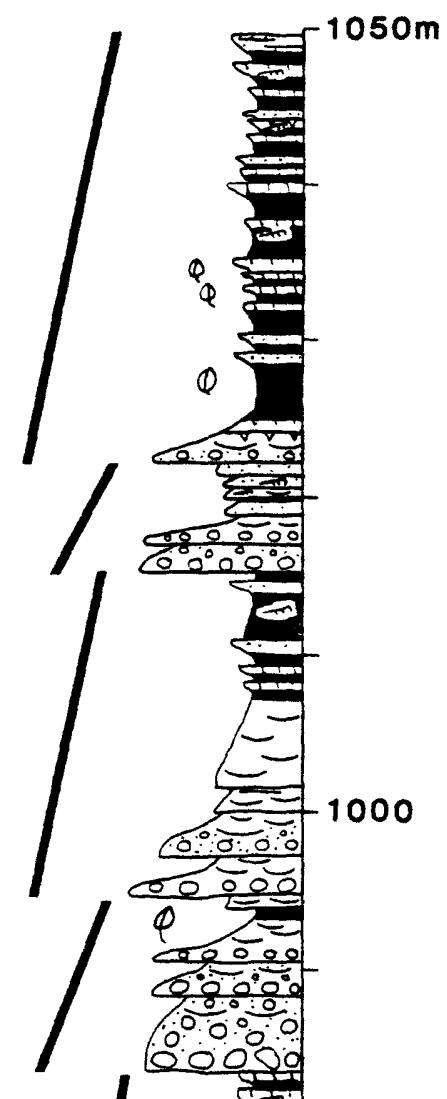

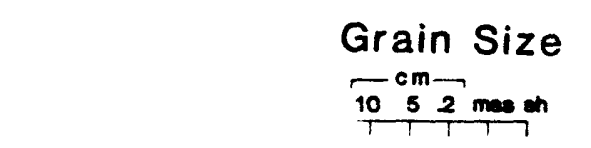

1

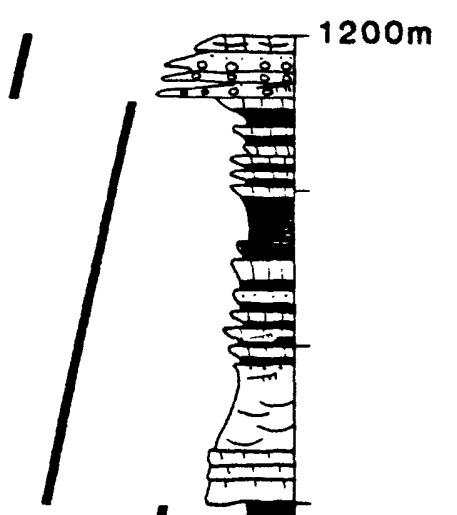




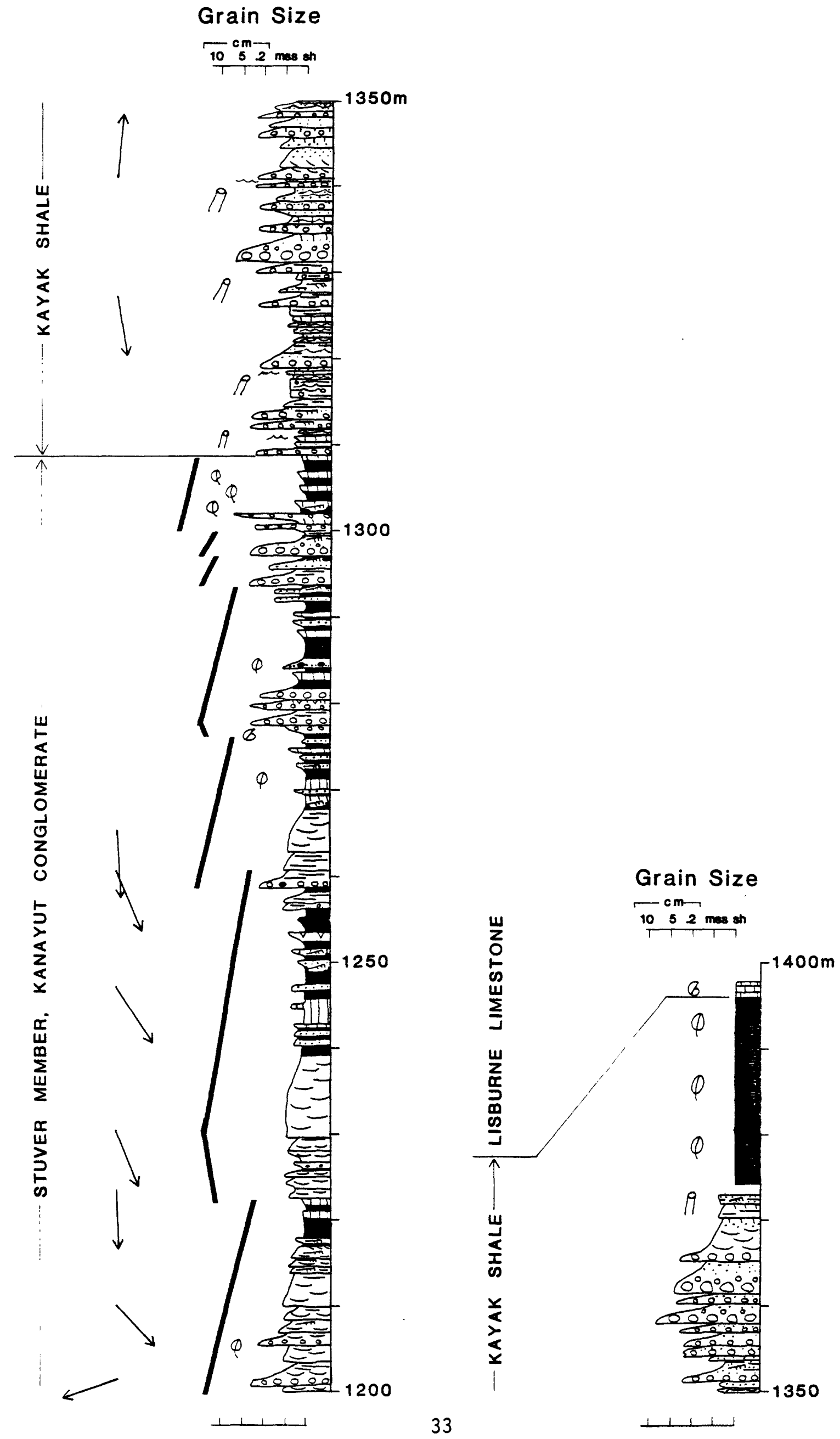




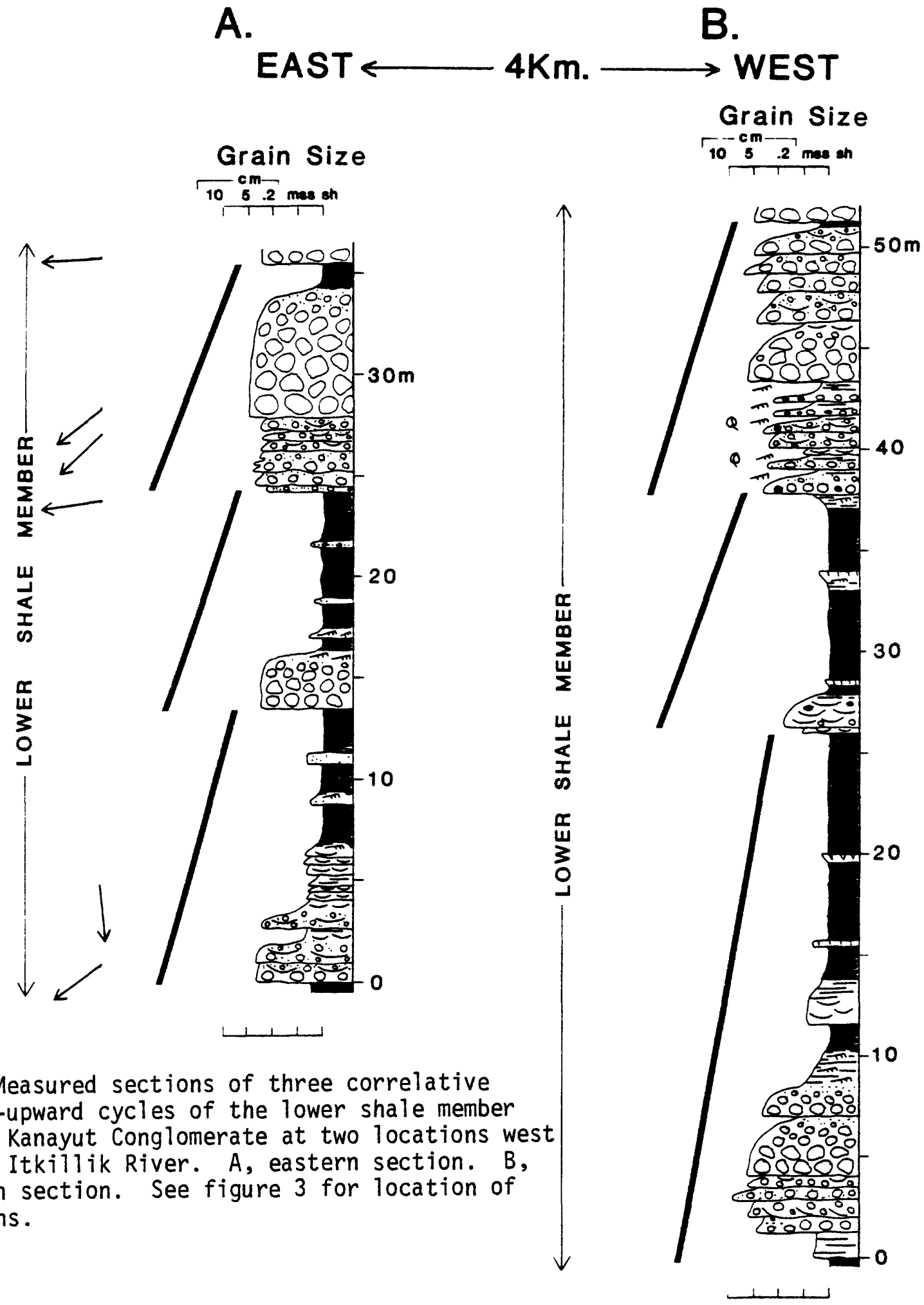


The upper cycle of section $B$ is about $14 \mathrm{~m}$ thick, but contains only $0.5 \mathrm{~m}$ of shale at its top. The lower $6 \mathrm{~m}$ consists of thinly interbedded conglomerate, conglomeratic sandstone, and sandstone having a maximum clast size of $3 \mathrm{~cm}$. The average bed of conglomerate in this part of the cycle is about $40 \mathrm{~cm}$ thick and the sandstone interbeds are characterized by trough cross-strata. The upper $9 \mathrm{~m}$ of the cycle contains a maximum clast size of 7 $\mathrm{cm}$ and an average conglomerate bed thickness of about $1.1 \mathrm{~m}$, indicative of the coarsening- and thickening-upward nature of the main part of this cycle. The top of the cycle grades abruptly from conglomerate with clasts as large as 4.5 $\mathrm{cm}$ to cross-stratified medium-grained sandstone that is $0.25 \mathrm{~m}$ thick to maroon shale.

The east-to-west changes within the three cycles are complex. For the lower cycle, the thickness changes from 13 to $26 \mathrm{~m}$, maximum clast size from 3 to $9 \mathrm{~cm}$, and conglomerate-plus-sandstone to shale ratio from $1: 1$ to $1: 2.5$. We thus have a westward increase in thickness, maximum clast size and amount of shale, which is not wholly consistent with expected changes in the direction of sediment transport. For the middle cycle, the thickness stays the same but the maximum clast size decreases westward and the conglomerate-plus-sandstone to shale ratio diminishes, which is what one would expect from westward transport. For the upper cycle, the thickness increases from 12 to $14 \mathrm{~m}$, the maximum clast size increases from 4 to $7 \mathrm{~cm}$, and the conglomerate-plussandstone to shale ratio increases slightly from west to east.

The two sections thus show variable downcurrent changes in cycle thickness and character, clast size, and conglomerate-plus-sandstone to shale ratios. No simple explanations for these changes, in terms of westerly transport of sediment by streams, is apparent. The possible overall transport of sediment toward the southeast in this area, as suggested by maximum clast size and regional paleocurrent data, may explain some of the variability. Additional studies of this type, especially involving three-dimensional analyses of cycle variability, are needed to understand major aspects of sediment distribution of the Kanayut depositional system.

\section{Shainin Lake area}

\section{Lower shale member}

A complete section of the lower shale member of the Kanayut Conglomerate was measured along the southernmost spur of an east-facing ridge near Ear Peak, east of Shainin Lake (sec. 13, T.13S., R.5E., the Chandler Lake Quadrangle). The section overlies the Hunt Fork Shale and underlies the middle conglomerate member of the Kanayut Conglomerate ( $f i g .8$ ); the basal sandstone member was not recognized at this location by either Brosge and others (1979b) or us.

The section is $510 \mathrm{~m}$ thick and consists of thirty-five major finingupward cycles that average $15 \mathrm{~m}$ in thickness. About 20 percent of the section is covered. The entire sequence generally coarsens upward as it approaches the base of the middle conglomerate member. Cycles typically begin with 1 to5-m-thick beds of conglomerate or conglomeratic sandstone overlain by troughcross-stratified or flat-stratified sandstone capped in some cycles by ripplemarked siltstone and red shale. The base of individual cycles may be marked by erosional scour into the underlying unit. The amount of shale, siltstone, 
Figure 8.--Measured section of the lower shale member of the Kanayut Conglomerate at Ear Peak, east of Shainin Lake. See Figure 3 for location of section. 


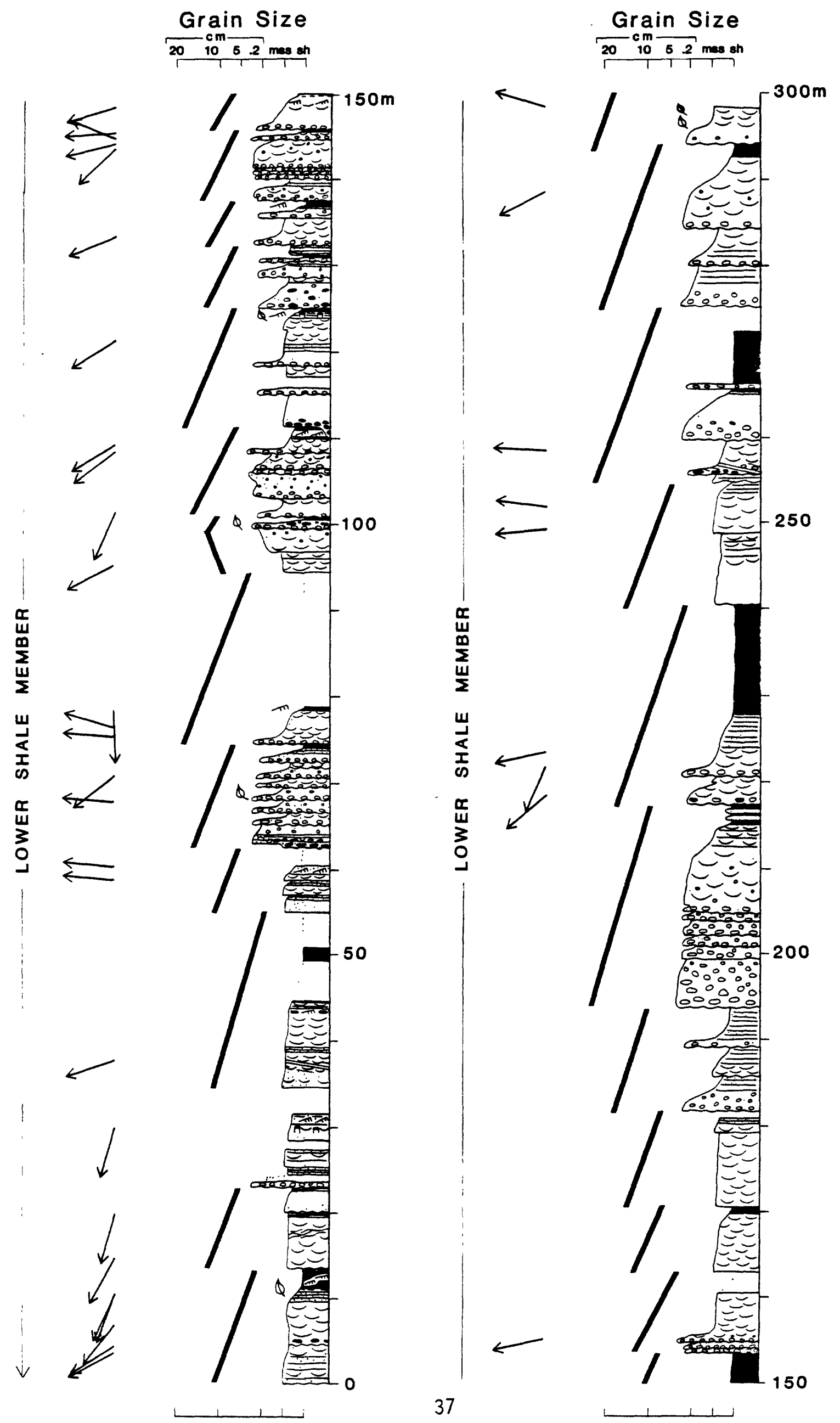




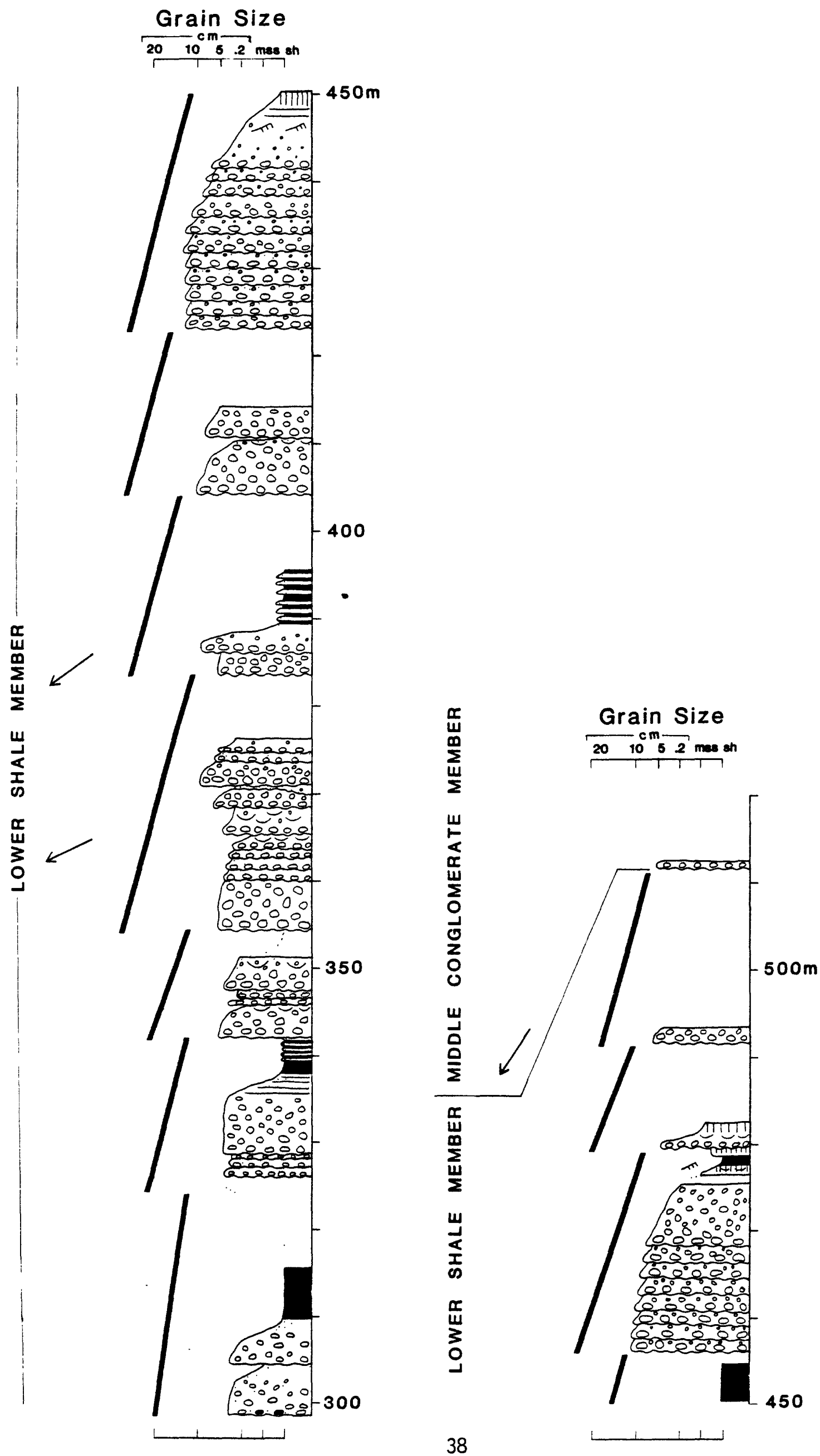


and fine-grained sandstone decreases upsection as the amount of coarse-grained sandstone and conglomerate increases. Rare burrows and plant fossils are present within beds of shale and fine siltstone in the lower half of the section.

The boundary of the lower shale member with the underlying Hunt Fork Shale is transitional and marked by the disappearance of marine megafossil debris and the initiation of distinct fining-upward cycles. The first distinct fining-upward cycle, at an elevation of 4820 feet $(1610 \mathrm{~m})$ forms the boundary between the two units. We interpret the boundary to mark the change upward from marine-dominated deposition to fluvial-dominated deposition. The distinct fining-upward cycles result from lateral and vertical accretion of meandering-stream channel and point-bar deposits. Epsilon cross-strata form inclined surfaces transecting the vertical sequence and may represent the actual inclined surfaces of point-bars within the system. Upper point-bar and floodplain deposits consist of shale and ripple-marked siltstone, with thin interbeds of fine-grained sandstone possibly representing crevasse-splay deposition.

The clast composition approximately $320 \mathrm{~m}$ above the base of the section is 87 percent chert, 11 percent quartz, and 2 percent quartzite. The clast composition $50 \mathrm{~m}$ below the base of the middle member consists of 82 percent chert, 13 percent quartz, 4 percent quartzite, and 1 percent argillite. The maximum clast size ranges from less than $1 \mathrm{~cm}$ near the base of the lower shale member to a maximum of $13 \mathrm{~cm}$ just below the base of the middle member.

Forty-four paleocurrent measurements from the lower shale member have a vector mean and standard deviation of $243^{\circ} \pm 29^{\circ}$. The measurements include 19 trough cross-strata, 17 primary current lineations, 3 flute casts, 2 tabular cross-strata, and 2 sites of clast long-axis orientation, and 1 oscillation ripple marking. Because the unidirectional indicators have a direction of sediment transport toward the southwest, bidirectional indicators have been preferentially assigned a similar transport orientation.

\section{Middle conglomerate member}

A complete section of the middle conglomerate member of the Kanayut Conglomerate was measured on the prominent cliff directly south of the intersection of Kayak Creek and Alapah Creek, about $8 \mathrm{~km}$ south-southeast of Shainin Lake (sec. 33, T.13S., R.5E., and sec. 5, T.14S., R.5E., Chandler Lake Quadrangle). The section is $526 \mathrm{~m}$ thick and is almost completely exposed, with relatively little cover ( $f i g .9$ ). Almost all covered intervals appear to be sandstone. The section is near the one measured by Bowsher and Dutro (1957).

The section is relatively uniform, consisting of thick beds of conglomerate that fine upward to conglomeratic sandstone and medium- to very coarse-grained sandstone. Shale is generally absent except for some thin intervals from $450 \mathrm{~m}$ to $490 \mathrm{~m}$ above the base of the section. The coarsest and most thick-bedded conglomerate is present in the middle part of the section, from $260 \mathrm{~m}$ to $440 \mathrm{~m}$ above the base. Thinner bedded and finer grained conglomerate with greater amounts of interbedded sandstone characterize the lower and upper parts of the section and mark the transition from the lower shale member and to the Stuver Member, respectively. Paleocurrents are 
Figure 9.--Measured section of the middle conglomerate member of the Kanayut Conglomerate south of Shainin Lake. See Figure 3 for location of section. 
Grain Size

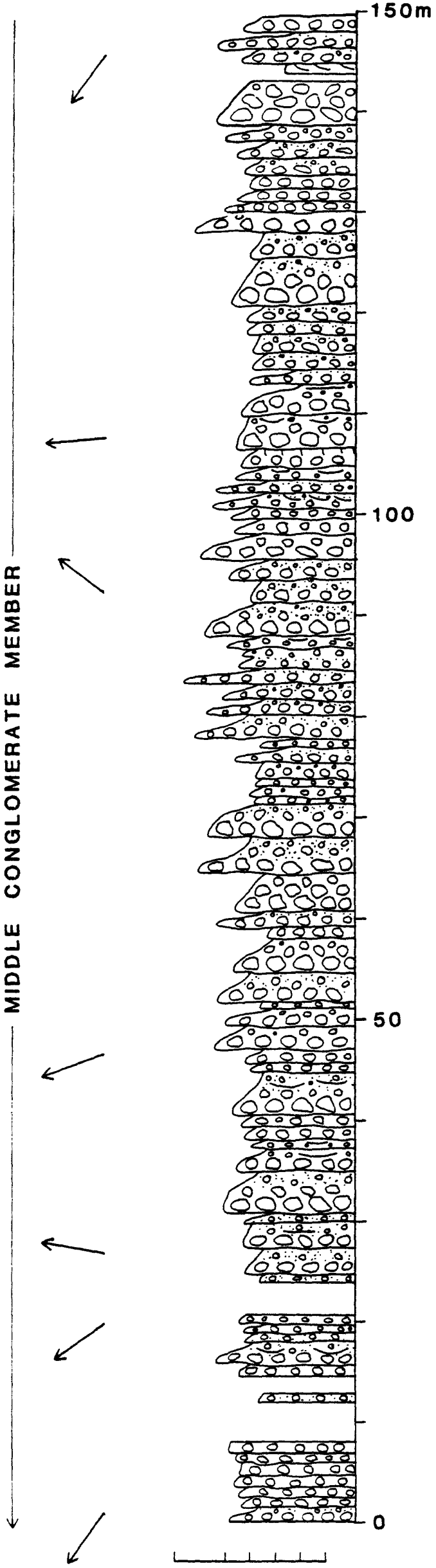

Grain Size

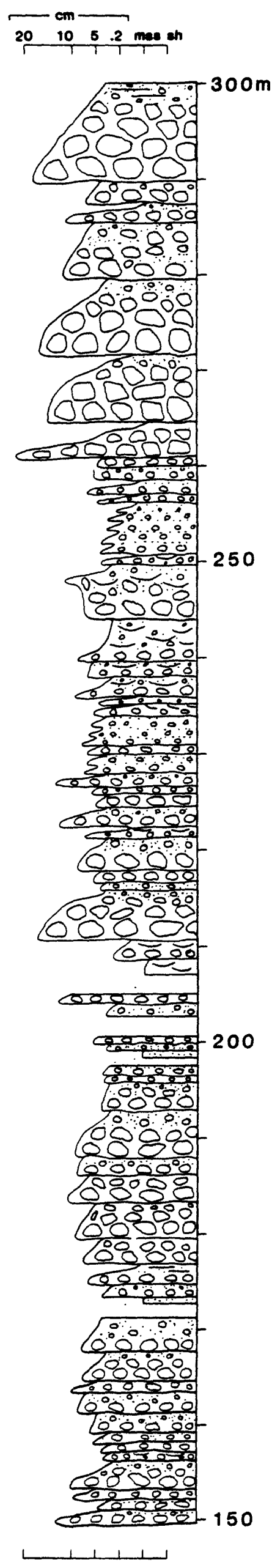




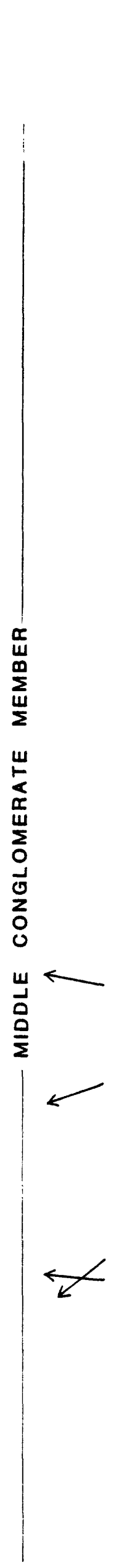

\section{Grain Size}
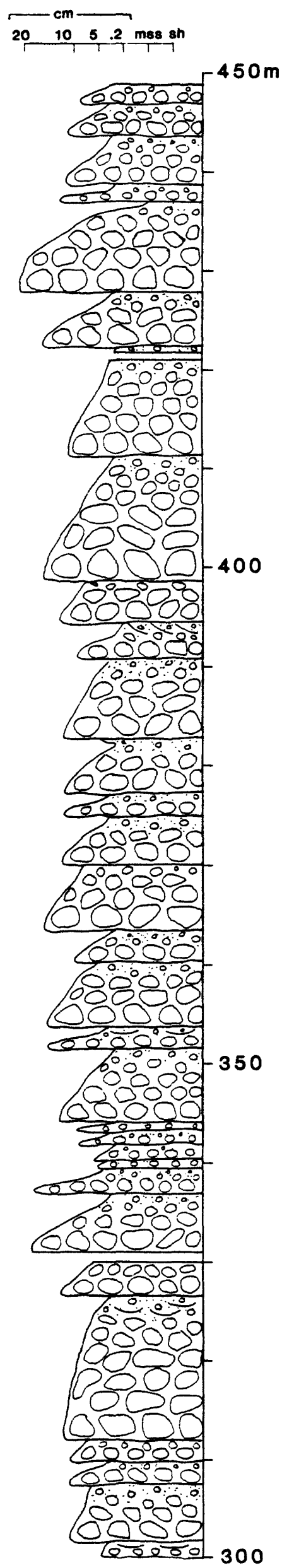

\section{Grain Size}
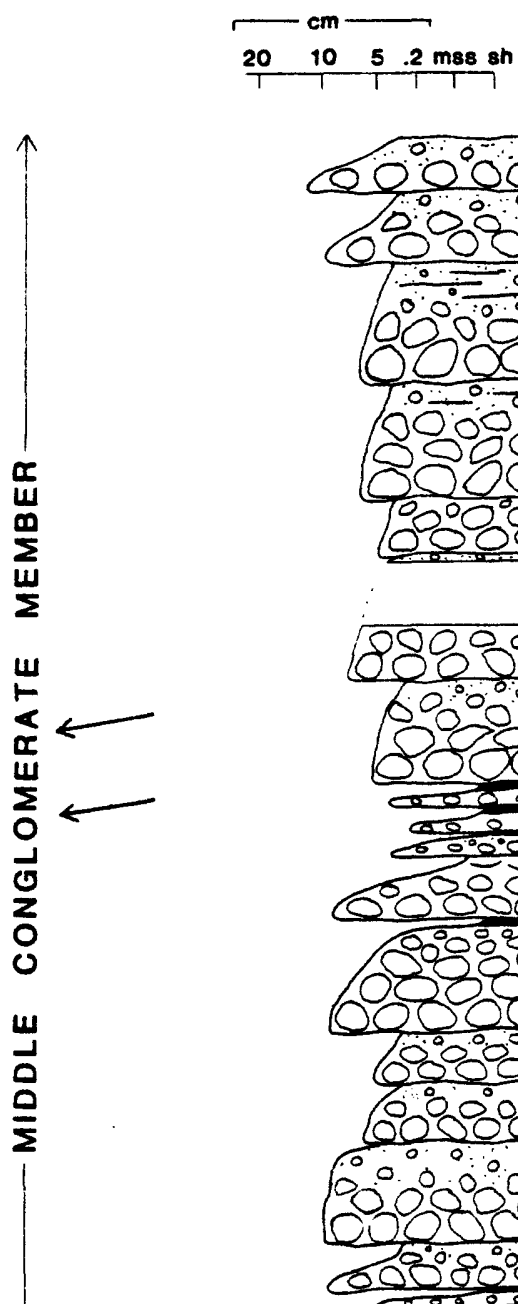

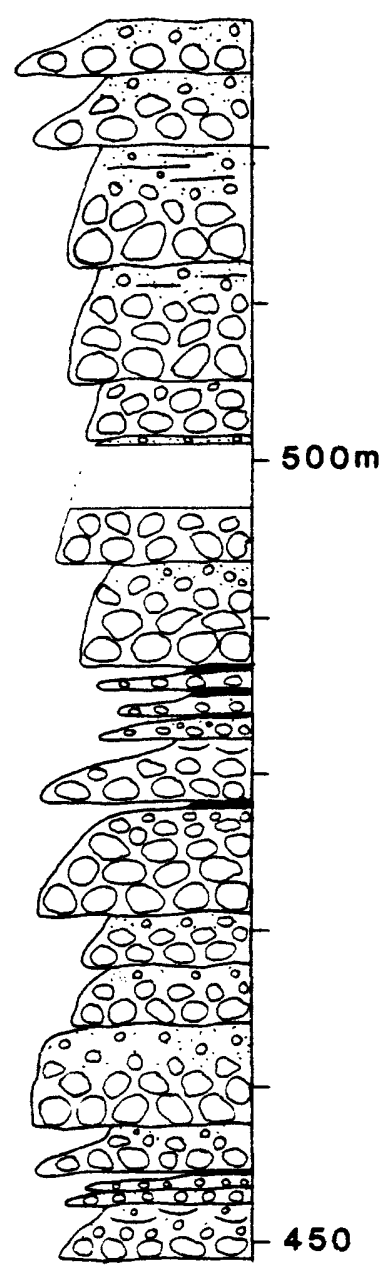


relatively uniform throughout the section and indicate west-southwesterly sediment transport. The mean and standard deviation of measurements of 15 localities of clast long-axis orientation and imbrication, 2 of tabular crossstrata and 1 of trough cross-strata from the section is $249^{\circ} \neq 25^{\circ}$.

The conglomerate beds typically have erosional bases characterized by coarser conglomerate resting on finer conglomerate, conglomeratic sandstone, sandstone, or shale. The conglomerate beds are most commonly massive and characterized by normal size grading of conglomerate clasts; well-developed imbrication, and clast long-axis orientation. The matrix consists of finer conglomerate and sandstone. Clast-supported conglomerate is most typical, although in finer grained conglomerate and conglomeratic sandstone, matrixsupported conglomerate is common. However, the matrix is never mud-rich and there is no indication of sediment transport and deposition by debris flows or related processes--all coarse-grained deposits appear to have resulted from streamflow processes.

Finer conglomerate typically has parallel stratification, poorly developed and marked by interlayering of coarser and finer conglomerate. Large- and medium-scale trough cross-strata and planar cross-strata are present in the upper parts of some conglomerate beds, but are most characteristic of the conglomeratic sandstone and sandstone units that rest without erosional scour on the lower beds of massive conglomerate.

The fining-upward sequences of conglomerate to sandstone or shale average about 2-3 $\mathrm{m}$ in the lower $260 \mathrm{~m}$ of the section, about $7 \mathrm{~m}$ in the middle $180 \mathrm{~m}$, and about $4 \mathrm{~m}$ in the upper $90 \mathrm{~m}$. The sequences record stream deposition, most likely that of a broad braidplain, in which braided streams transporting very coarse debris spread out over a broad aggrading depositional surface. There is no evidence for deposition by meandering streams and no indication for the development of fining-upward point-bar cycles. The lack of significant thicknesses of shale indicates that fine-grained floodplain deposits did not develop. The massive and parallel-stratified bars of conglomerate probably represent longitudinal gravel bars developed on the braidplain. The troughcross-stratified and planar cross-stratified beds probably represent transverse bars and dunes as well as deposition on the downstream flanks of the longitudinal bars. The thin shale intervals in the upper part of the section probably represent drapes of mud deposited over the bars during postflooding lowering of stream levels. In most of the sections, these mud drapes, if deposited, were probably eroded away before or during deposition of the overlying bed of conglomerate.

\section{Anaktuvuk Pass area}

Middle conglomerate member, Anaktuvuk River

A partial section of the middle conglomerate member of the Kanayut Conglomerate was measured on the east flank of the Anaktuvuk River Valley (NW1/4, T.14S.,R.3E., Chandler Lake Quadrangle). The member strikes westnorthwest and dips south at a low angle, forming low benches on the side of the valley floor. The section is $162 \mathrm{~m}$ thick and is incomplete, with neither a lower contact with the lower shale member or an upper contact with the Stuver Member exposed (fig. 10). The measured section probably forms a portion of the middle and upper parts of the middle conglomerate member. 

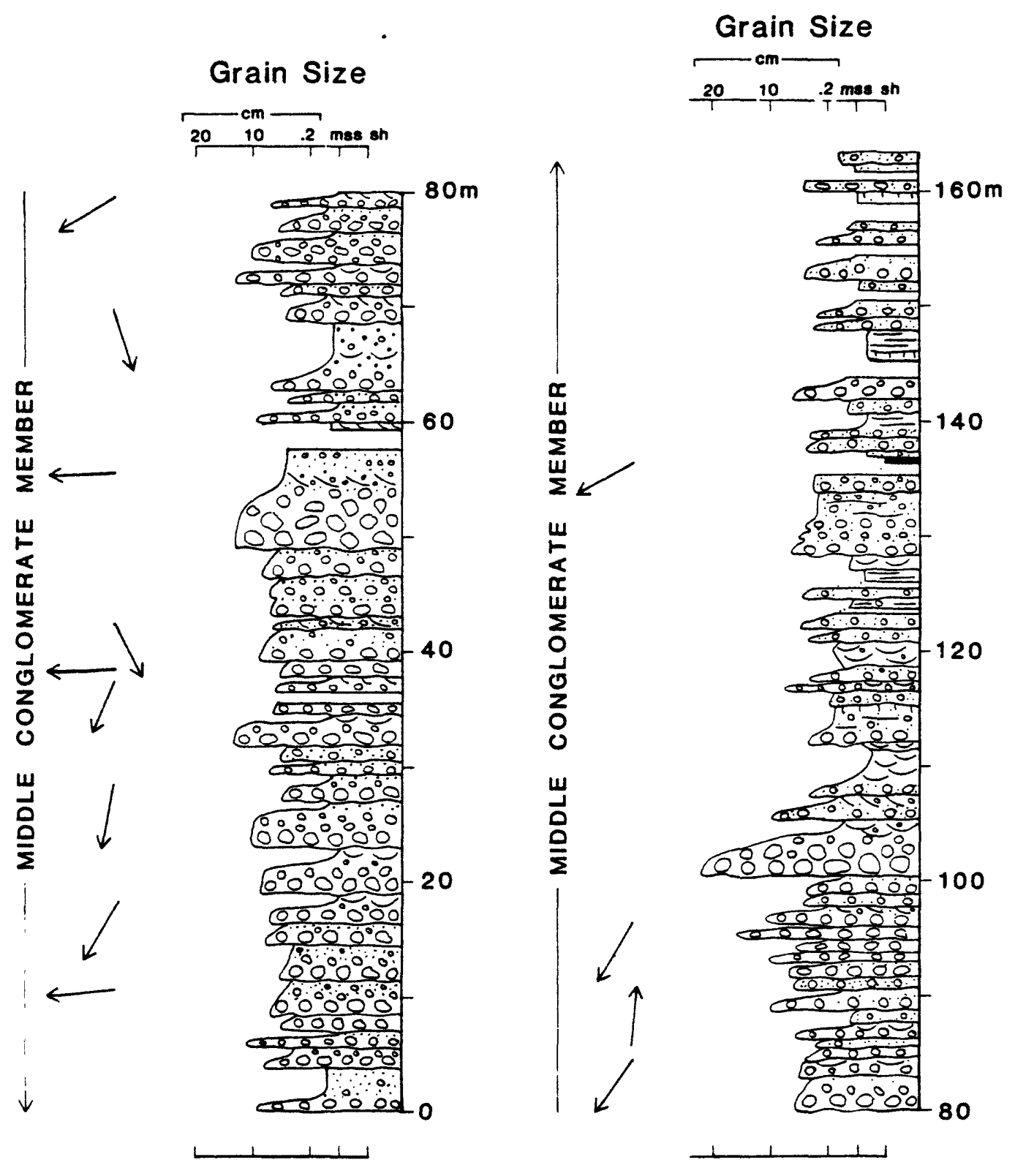

Figure 10.--Measured section of the middle conglomerate member of the Kanayut Conglomerate east of the Anaktuvuk River. See Figure 3 for location of section. 
The section consists predominantly of gray to buff-colored conglomerate and conglomeratic medium- to very coarse-grained sandstone. Fine-grained sandstone is uncommon, siltstone rare, and shale absent. The conglomerate forms lenticular beds that are chiefly clast-supported and as thick as 4.3 m. Clasts are moderately well sorted, rounded, and as large as $23 \mathrm{~cm}$ in maximum dimension.

Conglomerate forms the lower part of couplets that are characterized by an upward decrease in grain size and bed thickness. The maximum couplet thickness is $6.7 \mathrm{~m}$. The upper portions of couplets consist of massive, low-angle, and planar or trough-cross-stratified sandstone. Noncyclic amalgamated beds of sandstone or conglomerate and rare coarseningupward sandstone bodies are also present in the section.

The section was probably deposited by low sinuousity braided rivers. The conglomerate and sandstone couplets probably resulted from accretionary processes related to the growth and migration of longitudinal and transverse bars. Cross-stratified sandstone probably formed by migration of dunes on the tops of the larger bars. Maximum couplet size may provide a rough indicator of paleoflow depth during bankfull discharge. Paleosol development indicates periods of bar emergence.

Twenty-one paleocurrent measurements were obtained from the section (eight are not shown in Fig. 10, because their exact stratigraphic position is not known) including 9 of clast imbrication and long-axis orientation, 6 of tabular cross-strata, 5 of trough cross-strata and 1 flute cast. The mean and standard deviation of all measurements are $233 \pm 50^{\circ}$.

\section{Kanayut Conglomerate, John River}

An almost complete section of gently dipping Kanayut Conglomerate was measured along a ridge extending eastward from Ekokpuk Mountain to the floor of the John River Valley (SW1/4, T.37N., R.20W., Wiseman Quadrangle). This section is the southernmost one measured and totals $697 \mathrm{~m}$ in thickness. Toward the south and west, the Kanayut Conglomerate in general becomes finer grained and the middle conglomerate member becomes more sand-rich and depleted in conglomerate. As a result, the members of the Kanayut become more poorly defined in this area. In this section the upper and lower parts contain abundant shaly intervals which are commonly expressed as covered intervals. We therefore tentatively assign the lower $119 \mathrm{~m}$ to the lower shale member, the overlying $403 \mathrm{~m}$ to the middle conglomerate member, the next 175 to the Stuver Member, and the upper $10 \mathrm{~m}$ to the basal sandstone member of the Kayak Shale (fig. 11).

The underlying Hunt Fork Shale crops out in the valley at an elevation of $2150 \mathrm{ft}(715 \mathrm{~m})$ and the first outcrops of the Kanayut are found at $2600 \mathrm{ft}$ $(865 \mathrm{~m})$ on the ridge. The interval between the two outcrops is covered, but topographic expression suggests that the contact between the units is just below the first Kanayut exposures. There is, however, a possibility that as much as $140 \mathrm{~m}$ of the lower shale member of the Kanayut lie below the inferred contact and were not measured. Neither we nor Brosge and others (1979b) recognized the basal sandstone in this section.

The lower shale member consists of eleven fining- and thinning-upward cycles interpreted as the lateral and vertical accretion deposits of 
Figure 11.--Measured section of the upper part of the lower shale member, middle conglomerate member, and Stuver Member of Kanayut Conglomerate west of the John River. See Figure 3 for location of section. 
Grain Size

$20 \quad 10 \quad 5.2$ mse an

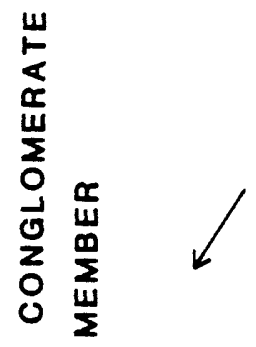

$\frac{1}{2}$
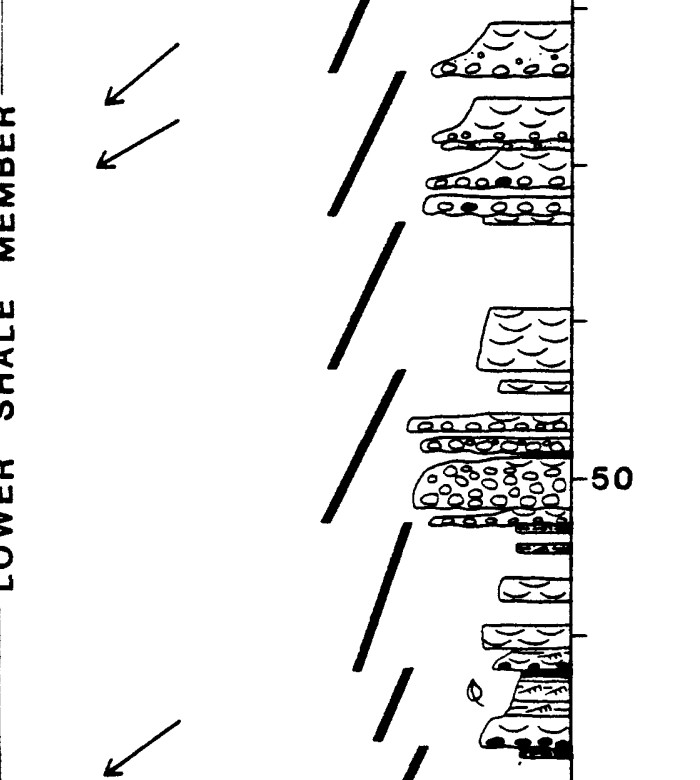

Grain Size

$20{ }_{10} \overline{5.2} \mathrm{mss} \mathrm{sh}$

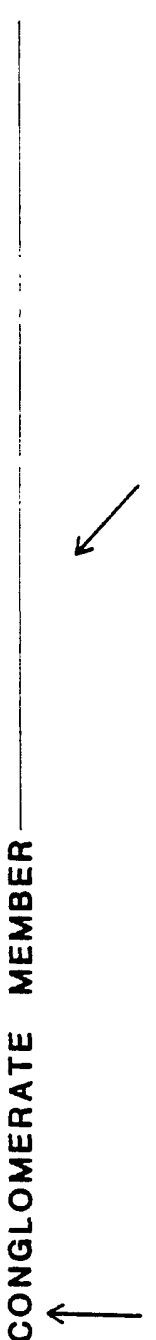

250

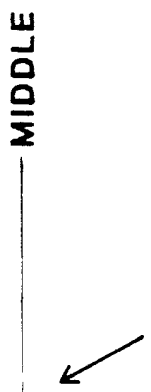

200

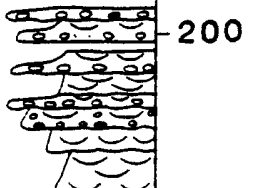

6ogero=

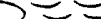

10

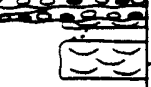

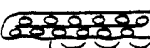

bry

tit:

ane

बख्यक्षक्ष

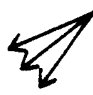




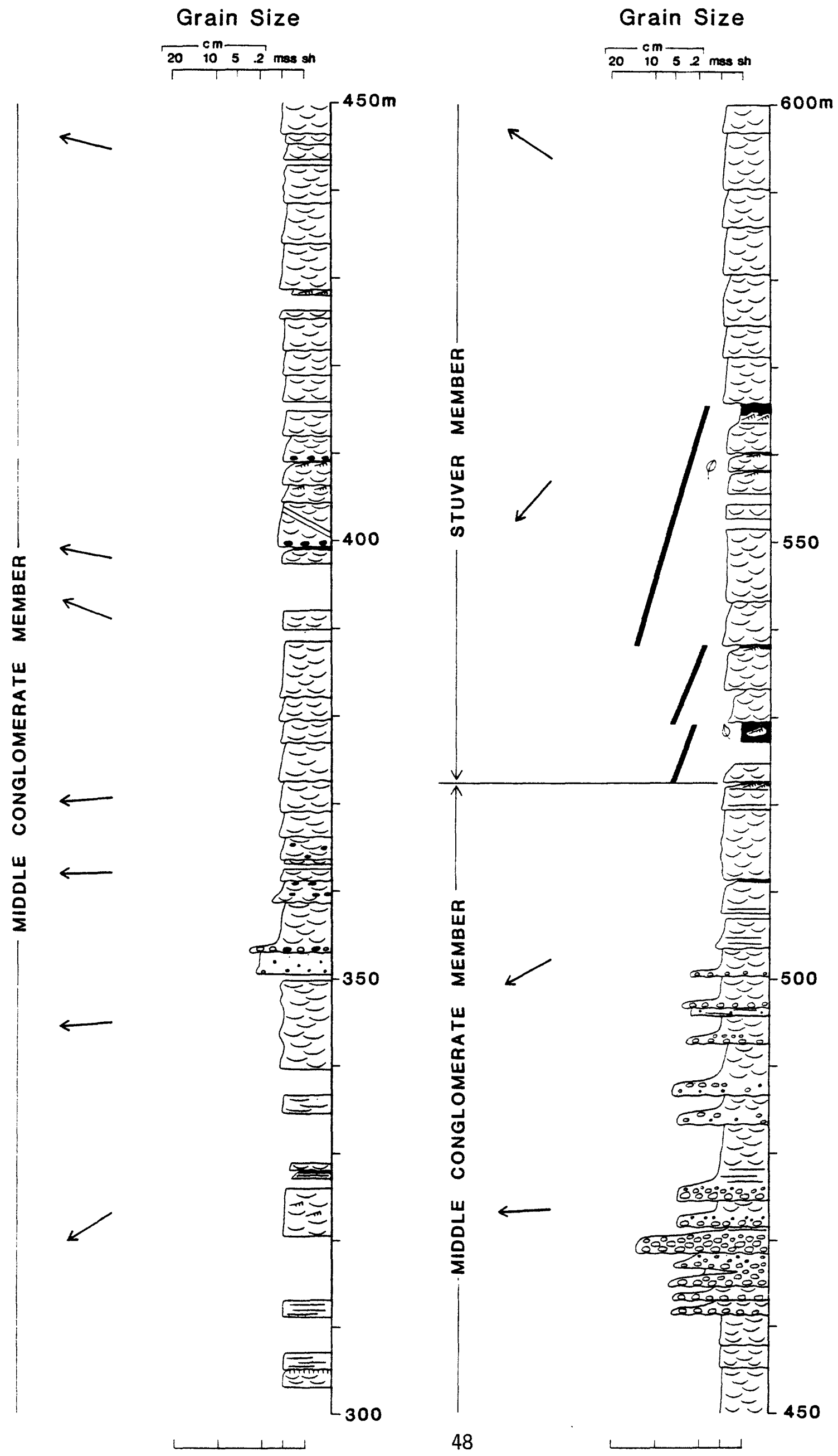


Grain Size

$20{ }_{10}^{5.2}$ mas an

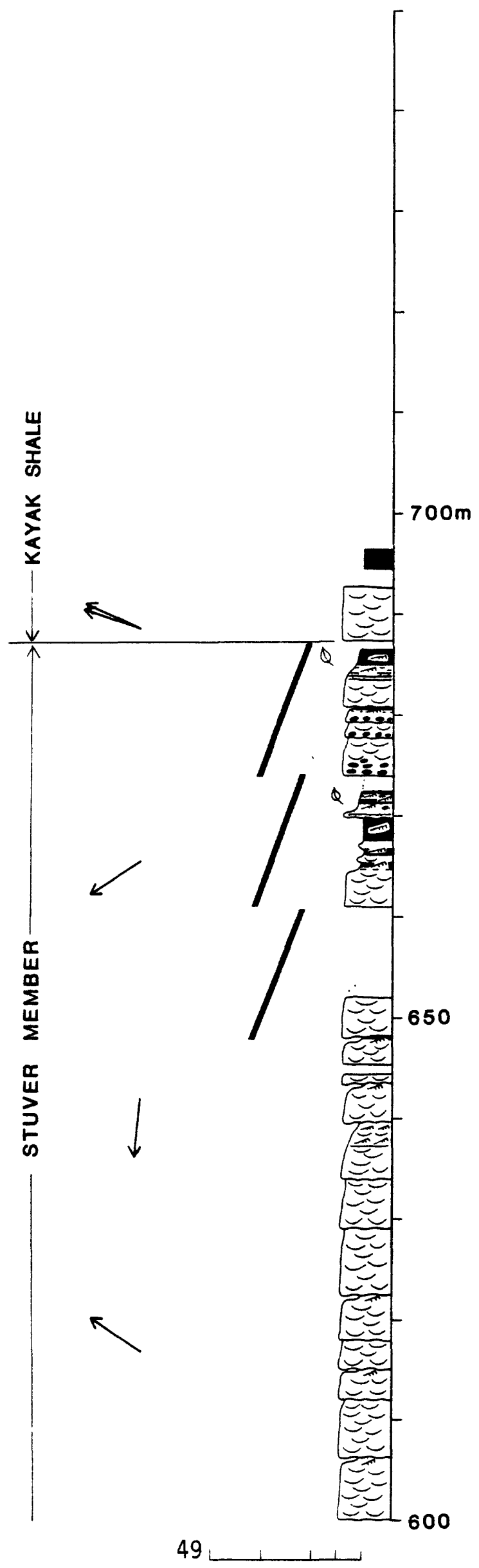


meandering rivers. The lower two cycles are about $16 \mathrm{~m}$ thick and the upper cycles about $8 \mathrm{~m}$ thick. Trough cross-stratified fine- to medium-grained sandstone and conglomerate with a maximum clast size of $1.5 \mathrm{~cm}$, are present in the lower parts of cycles and are inferred to be channel and lower point bar deposits. The coarser grained lower parts of cycles can include multiple fining-upward sequences separated by erosional surfaces. The coarser grained facies typically pass upward into trough-cross-stratified and locally flatstratified fine-grained sandstone, in turn overlain by ripple-marked and laminated very fine-grained sandstone, siltstone, and shale that contain plant fossils. These fine-grained rocks are interpreted to be upper point bar, levee, and floodplain deposits.

The transition from the lower shale member to the middle conglomerate member is marked by the disappearance of shale and siltstone. In contrast to sections measured to the north and east, the middle conglomerate member here is less conglomeratic and is marked by thick sequences of sandstone with little intervening shale. Conglomerate is most common within the lower $120 \mathrm{~m}$ of the middle conglomerate member. The maximum clast size is $5 \mathrm{~cm}$ and maximum conglomerate bed thickness is $3.5 \mathrm{~m}$.

A second conglomerate-rich interval from $460 \mathrm{~m}$ to $490 \mathrm{~m}$ above the base of the section contains conglomerate clasts as large as $14 \mathrm{~cm}$ and conglomerate beds as thick as $3.9 \mathrm{~m}$. The conglomerate beds generally grade upward into coarse- to medium-grained massive or cross-stratified sandstone, forming fining-upward conglomerate-sandstone couplets. They are less commonly overlain by a scour surface and another conglomerate bed, or by trough-crossstratified fine- to medium-grained sandstone.

Nonconglomeratic intervals in the middle conglomerate member consist of trough-cross-stratified, fine- to medium-grained sandstone up to $10 \mathrm{~m}$ thick that thin and fine upward and are separated by erosional surfaces. The sandstone is typically gray, but several red-brown oxidized horizons as thick as one meter are present. These oxidized horizons are typically parallel or subparallel to bedding, and are interpreted to be incipient paleosols. They are particularly common about $300 \mathrm{~m}$ above the base of the section. The middle conglomerate member was probably deposited by braided streams and contains features such as longitudinal and transverse bars, sand waves, and channels.

The transition between the middle and Stuver members is gradational but is marked by the disappearance of conglomerate and reappearance of shale and siltstone. Three fining-upward cycles that consist of trough-cross-stratified sandstone passing up into ripple-marked and laminated very fine-grained sandstone, siltstone, and shale are present at the base of the member. They are overlain by $45 \mathrm{~m}$ of trough-cross-stratified sandstone which lacks shale breaks and is similar to the middle conglomerate member, which is in turn overlain by 3 more fining-upward cycles. The cycles range from 5 to $23 \mathrm{~m}$ in thickness and appear not to be organized in a systematic manner in the section. The floodplain and levee deposits within cycles are as thick as $5 \mathrm{~m}$ and are best developed in the upper 3 cycles of the Stuver Member. The floodplain deposits in the cycle from $661 \mathrm{~m}$ to $673 \mathrm{~m}$ contain some massive to flat-stratified beds of fine-grained sandstone that contain abundant rip-up clasts and are as thick as several meters. These units are interpreted to be crevasse-splay deposits. The Stuver Member is overlain abruptly by the basal sandstone member of the marine Kayak Shale. 
Thirty paleocurrent measurements, consisting of 28 trough cross-strata and 2 tabular cross-strata were measured and indicate sediment transport toward the southwest. The mean and standard deviation of 15 measurements from the lower shale member are $239^{\circ} \neq 18^{\circ}$ whereas the mean and standard deviation of 8 and 7 measurements from the middle conglomerate and Stuver members are more westerly $-271^{\circ} \neq 15^{\circ}$ and $265^{\circ} \neq 48^{\circ}$, respectively. The mean and standard deviation of all 30 measurements from the section are $253 \neq 30^{\circ}$.

\section{Mount MacVicar area}

\section{Lower shale member}

A complete section of the lower shale member of the Kanayut Conglomerate was measured along a west-trending ridge on the southeast side of Mount MacVicar (T.15S., R.3W., Chandler Lake Quadrangle). The lower shale member is $260 \mathrm{~m}$ thick, conformably overlies marine strata of the basal sandstone member of the Kanayut Conglomerate, and is overlain by the middle conglomerate member of the Kanayut Conglomerate ( $\mathrm{fig} .12$ ). There is no apparent interfingering between the lower shale member and the basal sandstone member.

The section consists of 18 fining-upward cycles inferred to have been deposited by meandering rivers. The cycles range from 12 to $29 \mathrm{~m}$ in thickness. The coarsest cycles typically contain massive or crudely stratified conglomerate at the base, overlain by trough-cross-stratified fine- to coarse-grained sandstone, ripple-marked fine- to very fine-grained sandstone, and laminated very fine-grained sandstone, siltstone, and shale. Coarser grained lower parts of cycles contain multiple fining-upward sequences separated by erosional surfaces. The coarse-grained facies are interpreted to be river channel and lower point bar deposits and fine-grained facies to be upper point bar, levee, and floodplain deposits. Interspersed within finegrained intervals are some massive or thickly bedded bodies of fine-grained sandstone interpreted to be crevasse-splay deposits.

The beds of conglomerate are as thick as $3.25 \mathrm{~m}$ and the maximum clast size is $5 \mathrm{~cm}$. The amount of conglomerate increases upsection toward the contact with the middle conglomerate member. The two lowest cycles contain the greatest thickness of floodplain deposits and contain abundant fragments of plant fossils.

Paleocurrent measurements are fairly consistent throughout the section and indicate westward sediment transport. Two measurements at about $85 \mathrm{~m}$ above the base of the section indicate southeastward sediment transport. The mean and standard deviation for 16 measurements of trough cross-stratification and 1 of tabular cross-stratification in the section are $2610+57^{\circ}$.

\section{Okokmilaga Valley area}

\section{Lower shale member}

A very thick and complex fining-upward cycle in the lower shale member of the Kanayut Conglomerate was measured along a ridge flank north of Kikoyat Creek on the west side of the Okokmilaga River (sec. 19, T.34N., R.5W., Killik River Quadrangle). The fining-upward cycle is $37 \mathrm{~m}$ thick and consists of alternating beds of conglomerate and sandstone, bounded above and below by shale (fig. 13). The thick cycle is important because (1) it has been mapped 
Figure 12.--Measured section of the lower shale member of the Kanayut Conglomerate on the west flank of Mount MacVicar. See Figure 3 for location of section. 


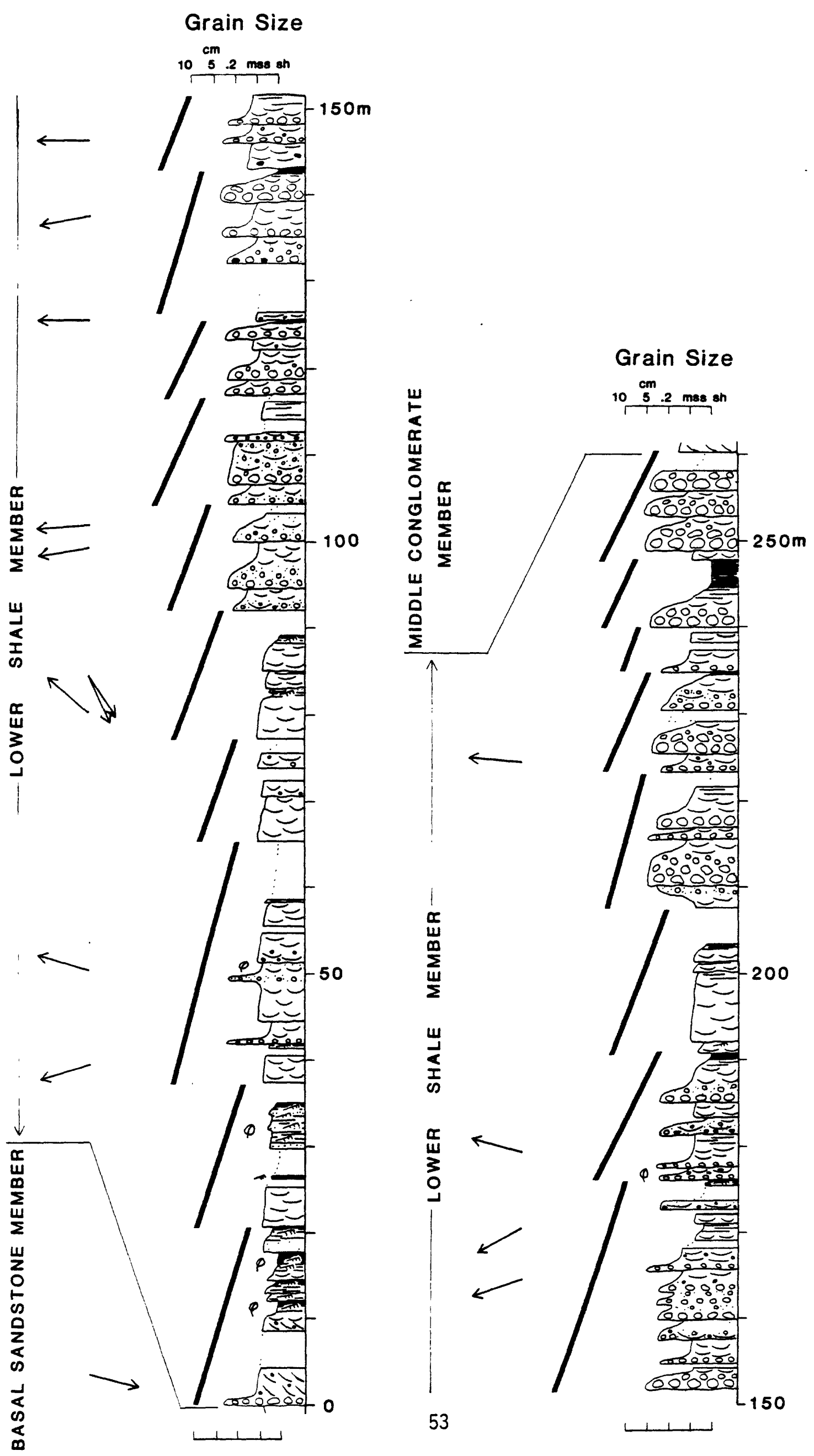



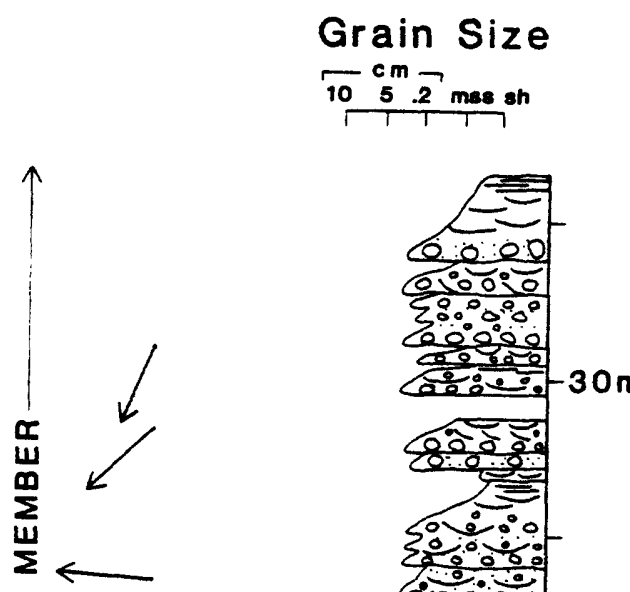

$\frac{w}{5}$
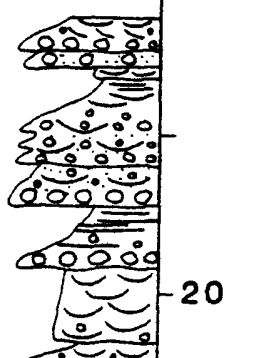

$605 \%$
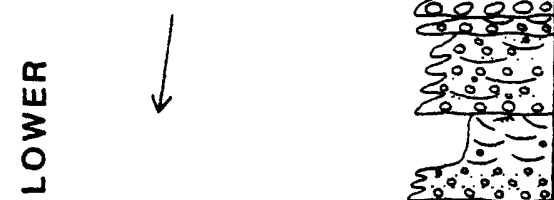

- 10
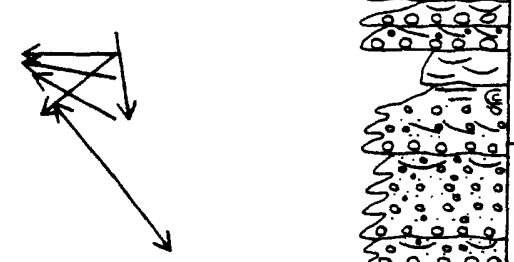

$30 \div 3$

0

0

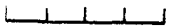

Figure 13.--Measured section of a thick, complex cycle in the lower part of the lower shale member of the Kanayut Conglomerate east of Okokmilaga River. See Figure 3 for location of section. 
extensively between the Killik and Okokmilaga Rivers in the central Brooks Range as a marker unit (unit Dklm of Brosge and others, 1979b), (2) it has been measured in several other sections of the lower shale member, and (3) it appears to form a correlatable unit, and (4) it forms a partly marine cycle. Scolithus-type burrows have been observed in the area where the present section was measured and in other areas where the thick cycle has been observed.

In the measured section along Kikoyat Creek, a series of fining-upward subcycles of conglomerate and cross-stratified sandstone comprise the larger cycle. The subcycles are bounded by thick sandstone beds that are present at the following intervals above the base of the cycle: $7 \mathrm{~m}, 13 \mathrm{~m}, 20 \mathrm{~m}, 27 \mathrm{~m}$, and $35 \mathrm{~m}$. These sandstone units are as thick as $3 \mathrm{~m}$ and contain trough crossstrata. The conglomeratic beds are massive, parallel-stratified, or crossstratified, and do not generally form well-defined fining-upward components of the subcycles. The maximum clast size measured was $3 \mathrm{~cm}$ and clasts of this size are found throughout the section, suggesting that the section does not form an overall fining-upward cycle. Although no marine trace fossils were found in the measured section, Scolithus-type trace fossils are present in the cycle several tens of meters to the east and west of the line of section.

Paleocurrents from the thick cycle indicate variable transport toward the west and south. We measured 16 paleocurrent indicators ( 5 are not shown in fig. 13 because their exact stratigraphic position is not known), including planar and tabular cross-strata, clast imbrication and long-axis orientations, and primary current lineation. The mean and standard deviation of the measurements are $235^{\circ}+65^{\circ}$. The variable nature of the paleocurrents may reflect intermixing of the fluvial transport and shallow-marine transport in the cycle.

We believe that the thick mappable cycle in the lower part of the lower shale member represents a marine incursion during deposition of the dominantly fluvial lower shale member. The unit may be recognizable as far east as the Atigun River (fig. 3). Parts of the section that contain well-sorted sandstone, laterally extensive single-pebble-thick layers of conglomerate, and variably oriented medium-scale cross-strata also argue for a marine rather than fluvial origin. In the lower part of the measured section, about $6 \mathrm{~m}$ above the base, is a prominent recumbently folded bed of medium- to coarsegrained sandstone with fluid-escape structures. The folds suggest slumping in a direction of $278^{\circ}$. Small-scale syndepositional folds of this nature have not been observed in fluvial parts of the Kanayut sequence and may also argue for a marine origin.

Stuver Member

A well-exposed and complete section of the Stuver Member of the Kanayut Conglomerate was measured along a ridge crest west of the Okokmilaga River (sec. 8, T.33N., R25E., Killik River Quadrangle). The west-dipping member crops out in a saddle west of a prominent ridge formed by the top of the middle conglomerate member at the base of the section. Individual resistant beds of the Stuver Member form topographic ridges within the section.

Approximately $162 \mathrm{~m}$ of section were measured, with covered intervals totalling only 5 percent ( $\mathrm{fig} .14$ ). The well-defined boundary with the 
Figure 14.--Measured section of the Stuver Member of the Kanayut Conglomerate, west side of Okokmilaga River. See Figure 3 for location of section. 

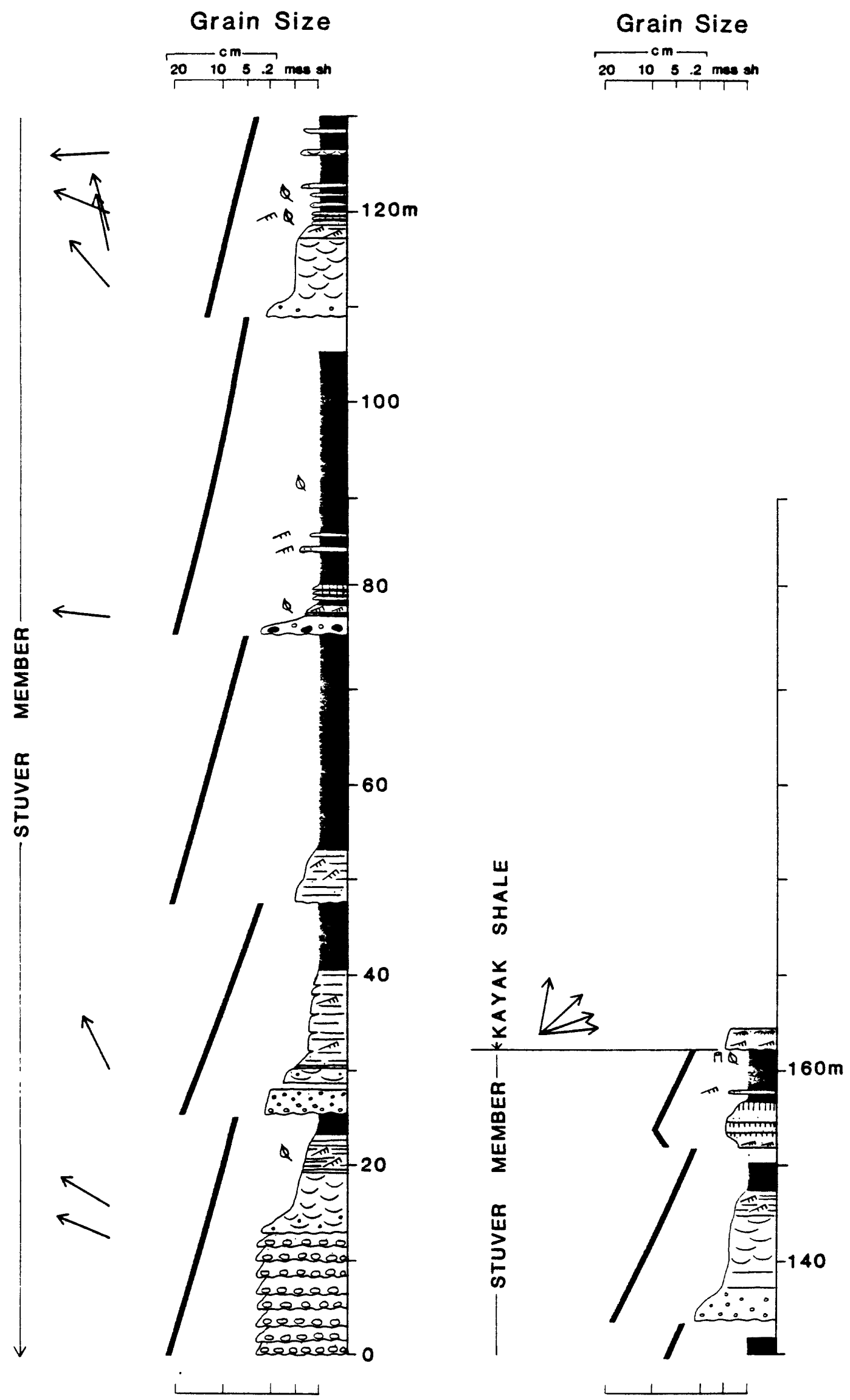
underlying middle conglomerate member is at the top of an interval of conglomerate and trough-cross-stratified sandstone couplets that have a maximum clast size of $3 \mathrm{~cm}$.

The Stuver Member here consists of 7 major fining-upward cycles, with red and black shale comprising nearly 50 percent of the section. The individual cycles have erosional scours at their base. The basal beds of cycles consist of either conglomeratic sandstone containing clasts 1 to $2 \mathrm{~cm}$ in length or sandstone that is very coarse-grained in the lower part of the Stuver Member and very fine-grained at the top. The basal bed of the fourth cycle contains rip-up clasts of shale eroded from the underlying unit. The lowest bed of each cycle is typically massive to crudely stratified. It grades upward into trough-cross-stratified fine- to medium-grained sandstone and laminated shale. The shale forming the top of each cycle is as thick as $24 \mathrm{~m}$ and is typically red in color but may also alternate with black shale. Plant fossils, root impressions, paleosols with ferruginous nodules, and very finegrained sandstone are also present within the shale intervals.

The fining-upward cycles are inferred to result from lateral and vertical accretion of sediments in a meandering stream. The coarser grained sediments at the base of the cycles represent channel and lower point-bar deposits and the finer grained sediments represent upper point-bar and floodplain deposits. The thick shale sequences within the Stuver Member are thought to represent extensive floodplain deposits, with variability in shale color probably dependent on whether the sediment was deposited under oxidizing or reducing conditions. Red shale was probably deposited in topographically higher oxidizing zones of the floodplain and black shale in swampy reducing environments. Interbedded shale and very fine-grained sandstone units probably represent levee and crevasse-splay deposits within the cycles.

The uppermost cycle has a coarsening-upward interval at its base and an overlying fining-upward interval. Burrows and plant fossils are found in the black shale at the top of the cycle. We interpret this cycle to have formed in response to alternating marine and nonmarine deposition. The well-defined contact of the Stuver Member with the overlying basal shallow-marine sandstone of the Kayak Shale is marked by the appearance of thin-bedded fine-grained sandstone containing oscillation ripple marks, ball and pillow structures, and slumped intervals within a coarsening-upward sequence. Above the contact, paleocurrent directions shift from a dominantly northwesterly orientation in the Stuver Member to a dominantly northeasterly direction in the overlying Kayak Shale.

Ten paleocurrent measurements from the Stuver Member have a vector mean and standard deviation of $304^{\circ} \neq 30^{\circ}$. These measurements include 4 trough cross-strata, 3 primary current lineations, 2 current ripple markings, and 1 interval of clast long-axis orientation. The northwesterly direction here may have been influenced by structural rotation of the section to an atypical north-trending strike.

\section{Killik River Area}

Lower shale and middle conglomerate members

A section of Kanayut Conglomerate $775 \mathrm{~m}$ thick was measured along the base of the west side of the Killik River Valley between Irivik and Enekalikruak 
Creeks (SE 1/4, T.33.N, R.20E., Killik River Quadrangle). The section crops out on the southern flank of an east-trending anticline and probably includes all of the lower shale member and most of the middle conglomerate member (fig. 15). The upper part of the section is truncated by the Toyuk Thrust and is poorly exposed. As a result, all of the Stuver Member and at least part of the middle conglomerate member are probably cut out. The lower $240 \mathrm{~m}$ of the measured section is assigned to the lower shale member and the upper $530 \mathrm{~m}$ to the middle conglomerate member. The middle conglomerate member in the Killik River area is finer grained and richer in sandstone compared to areas farther north and east making it less easily distinguished from the underlying and overlying units. We placed the boundary between the lower shale member and middle conglomerate member at the top of the stratigraphically highest shale unit thicker than $2 \mathrm{~m}$.

The lower $240 \mathrm{~m}$ of the section consists of interbedded conglomerate and sandstone with partly covered intervening intervals of fine-grained sandstone, siltstone, and shale. Strata below the base of the measured section are not exposed, but topographic expression and projection of the base of the section along strike to the northwest strongly suggests that the lowest outcrop marks the contact between the Hunt Fork Shale and the lower shale member of the Kanayut Conglomerate. The basal sandstone member of the Kanayut Conglomerate is not present. The basal $4 \mathrm{~m}$ of the section consists of a coarsening-upward cycle of cross-stratified medium-grained sandstone to pebble conglomerate. This cycle differs from those higher in the section and we interpret it to be the top of the marine Hunt Fork Shale.

The overlying lower shale member of the Kanayut consists of 12 finingupward cycles which are about 25-30 m thick near the base and 15-20 m thick near the top. The lower parts of the cycles consist of massive, crudely parallel-stratified or cross-stratified pebble conglomerate and conglomeratic sandstone that is channeled into the underlying cycles. The coarse-grained units contain clasts as large as $5 \mathrm{~cm}$ and have numerous thinner fining-upward sequences that are separated by erosional surfaces. The coarse-grained basal parts of the cycles grade upward into trough cross-stratified, parallelstratified, or massive medium- to coarse-grained sandstone. The upper parts of the cycles are mostly poorly exposed, but some outcrop and float show that they consist of brown to black, ripple-marked and laminated fine-grained sandstone, siltstone and shale. The fine-grained upper parts of cycles decrease in thickness upward from 10-20 m near the base to 5-10 m near the top of the lower shale member.

The fining-upward cycles of the lower shale member are interpreted to represent the lateral and vertical accretion deposits of meandering rivers. The coarse-grained basal parts of the cycles are inferred to be channel and lower point-bar deposits and the fine-grained upper parts to be upper pointbar, levee and floodplain deposits. Scolithus-type burrows in float $50 \mathrm{~m}$ above the base, however, may indicate that the fine-grained parts of some cycles contain marine deposits. A marine origin for some strata may also be indicated by small-scale recumbent folds which occur in very fine-grained sandstone $105 \mathrm{~m}$ above the base of the section.

Conglomerate-sandstone couplets predominate in the lower part of the middle conglomerate member. The couplets consist of massive to tabular crossstratified beds of conglomerate that contain clasts as large as $4 \mathrm{~cm}$ and were 
Figure 15.--Measured section of the lower shale member and middle conglomerate member of the Kanayut Conglomerate, west side of Killik River. See Figure 3 for location of section. 


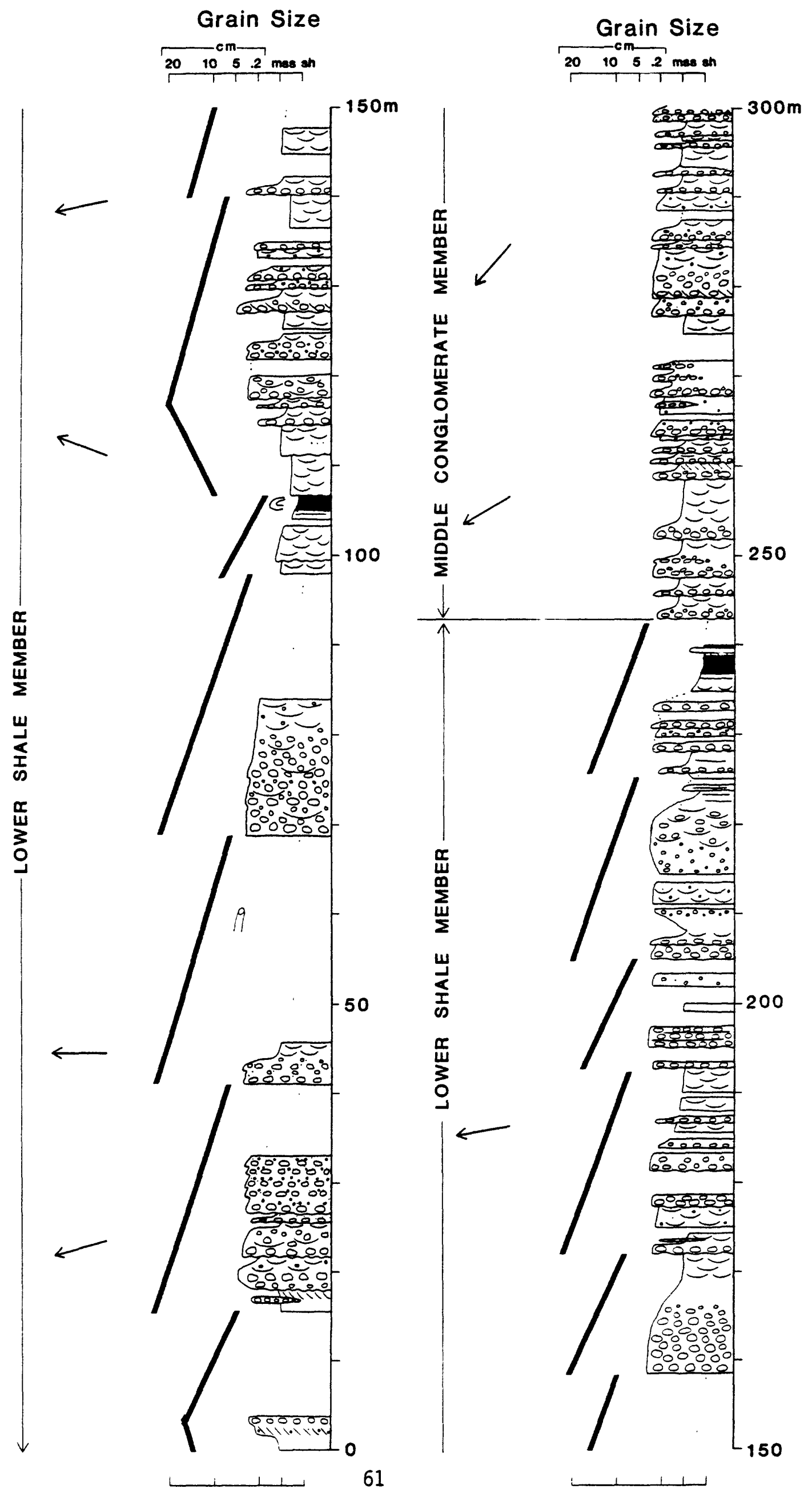


Grain Size

$20 \mathrm{~cm}_{10} \overline{5.2}$ mas $\mathrm{sh}$

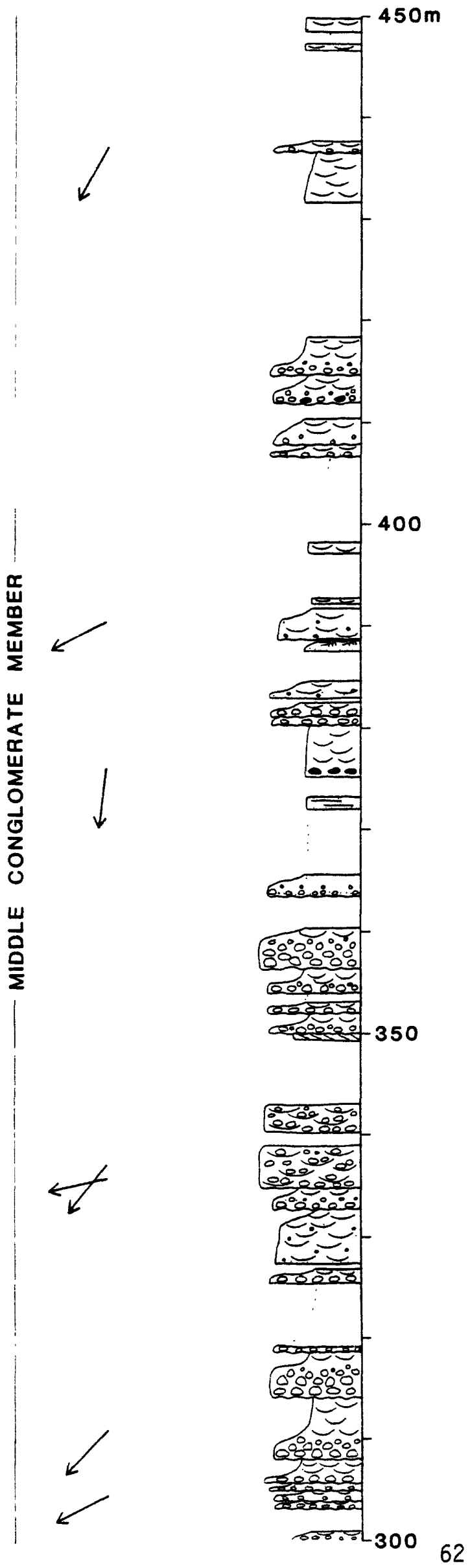

Grain Size

ro $\quad \mathrm { cm } \longdiv { 5 . 2 }$ mas on
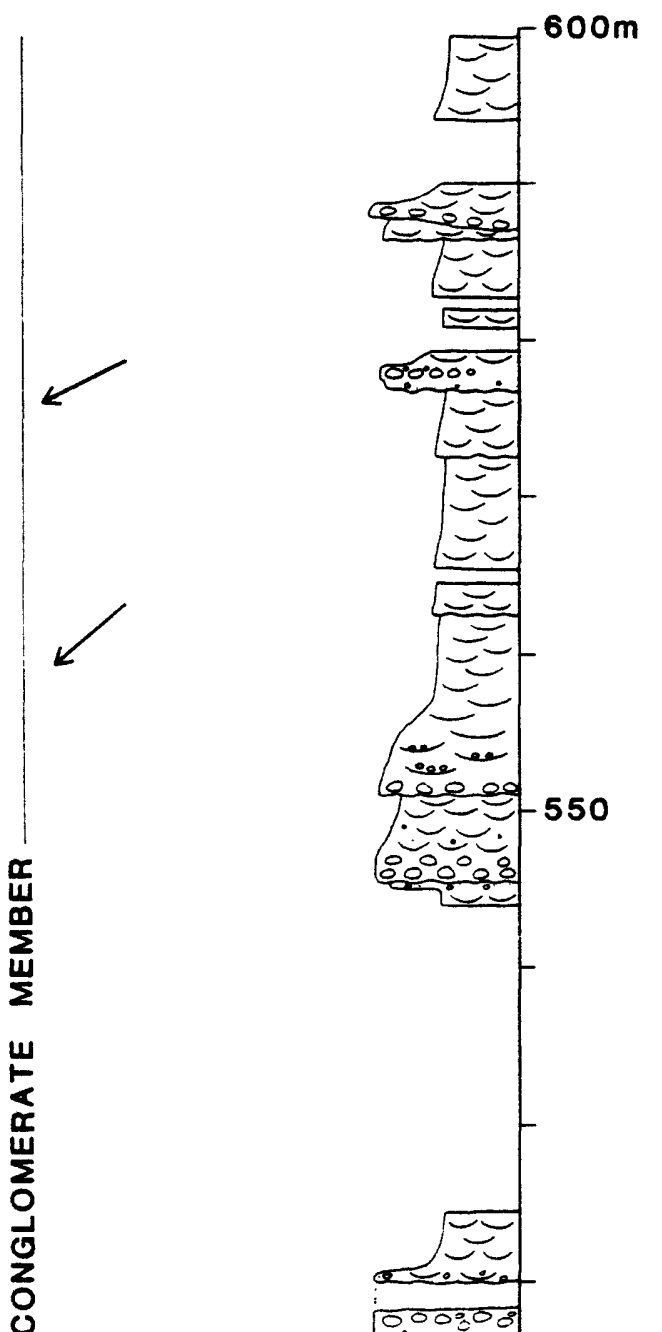

80000

$=$

$=$

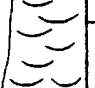

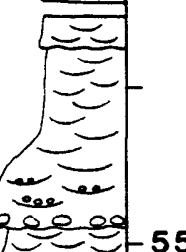

geo 550

$0 \div$

님

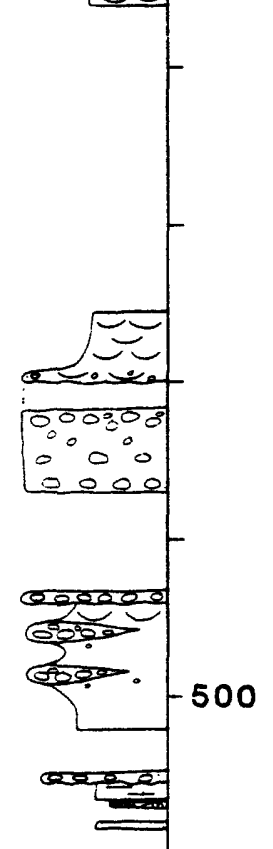


Grain Size

$20 \quad 10 \quad 5 \quad 2$ mas sh
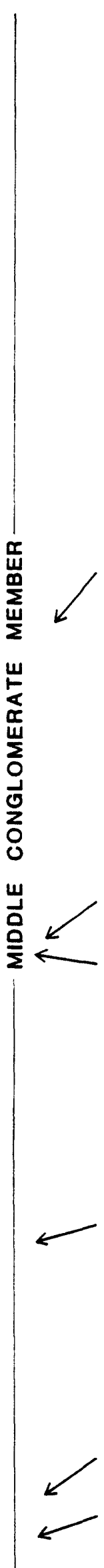

Grain Size

$20 \quad 10 \quad 52$ mas an

$750 m$

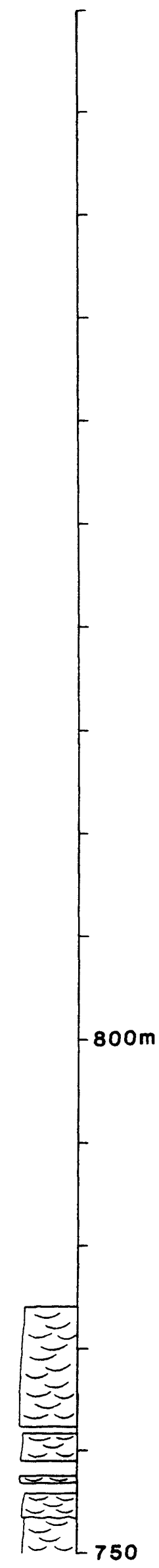


deposited on erosional surfaces. The conglomerate beds are overlain by trough cross-stratified sandstone that is medium- to coarse-grained and commonly conglomeratic. The abundance of conglomerate generally decreases upward in the section and the sandstone becomes finer grained. Above $390 \mathrm{~m}$, the coarsegrained basal parts of the couplets consist mostly of pebbly sandstone with clasts as large as $2 \mathrm{~cm}$ and abundant rip-up clasts and the finer grained upper parts are thicker and consist of fine- to medium-grained sandstone.

In the upper $175 \mathrm{~m}$ of the section, conglomerate is virtually absent and fine- to medium-grained trough-cross-stratified sandstone is most abundant and forms thinning-upward cycles. Within these cycles, bedding thickness decreases from about $10 \mathrm{~cm}$ at the base to $1-2 \mathrm{~cm}$ at the top, although the grain size decreases only slightly over the same interval. Shale and siltstone are rarely exposed in the middle conglomerate member.

The coarse-grained conglomerate-sandstone couplets of the lower part of the middle conglomerate member indicate deposition by gravel-dominated braided streams. The sandstone-dominated upper part of the middle conglomerate member was deposited by sandy braided streams. Some of the sandstone-dominated cycles, in the intervals $455 \mathrm{~m}$ to $496 \mathrm{~m}$ and $525 \mathrm{~m}$ to $635 \mathrm{~m}$, contain caps of thin-bedded rippled siltstone. These cycles and the overall fining-upward character of the section probably indicate a transition to the Stuver Member.

Paleocurrents from the lower shale member indicate that sediment transport was predominantly westward. Directions from the middle conglomerate member are more southwesterly, indicating a more southerly direction of sediment transport during deposition of this member. The mean and standard deviation of 27 paleocurrent indicators from the entire section are 2390. $23^{\circ}$. The mean and standard deviation for the lower shale member are $266^{\circ}$. 140 and for the middle conglomerate member $233^{\circ}+20^{\circ}$.

\section{CONGLOMERATE CLAST SIZE DATA}

The maximum dimension of the largest conglomerate clast was measured at each station where conglomerate was observed, in order to determine overall changes in the size of material transported by the Endicott Group depositional system. In our previous reports, we presented maximum clast size data collected during the 1978 and 1979 field seasons at 81 locations in the Kanayut Conglomerate and 28 locations in the Kekiktuk Conglomerate. In this report, we present data collected from the Kanayut Conglomerate at 82 additional locations during the 1980 field season.

Because our earlier data were not well dispersed geographically, we attempted-during the 1980 field season to collect measurements in areas from which we previously had no data. In addition, our previous data were commonly taken from only a limited portion of the entire stratigraphic thickness of a member or formation so that many data points were representative of only a limited stratigraphic thickness of the unit. During the 1980 field season, we collected data primarily from bouldery rubble in modern alluvial fans of streams draining restricted areas. Care was taken to choose streams draining only exposures of Kanayut Conglomerate and to measure clasts in boulders obviously derived from the Kanayut by fluvial processs. By this method, we 
were able to more easily sample large thickness of stratigraphic section for the largest clast contained in their conglomeratic strata. However, the map distribution of maximum clast sizes must still be interpreted cautiously with regard to paleogeography because of the presence of significant amounts of structural shortening, including at least three major thrust faults within the outcrop belt. Nevertheless, several major conclusions can be drawn from the available data.

We have compiled a map of maximum clast size data from the Kanayut Conglomerate collected during the 1978, 1979 and the 1980 field seasons (fig. 16). The 1980 data were collected primarily between the Killik River and the Sagavanirktok River. The middle conglomerate member generally contains the largest clasts and we collected most data from it.

The largest clasts we observed in the Kanayut Conglomerate are $23 \mathrm{~cm}$ in length and are located near Shainin Lake. To the west and south of Shainin Lake, the clast size decreases regularly and dramatically. Conglomerate is rare in the Kanayut north of the Noatak River, demonstrating a marked westward decrease in clast size away from Shainin Lake. Clast size also decreases southeast of Shainin Lake, as far east as the longitude of the Canning River, where the largest clasts are $5 \mathrm{~cm}$ in size. The distribution of decreasing clast sizes around the Shainin Lake region suggests that it may mark an entry site of a major trunk system into the Kanayut depositional basin.

A second major trunk system may be indicated by the clast size data in the northern and eastern outcrops of the Kanayut. Clast sizes in that region decrease from a maximum of $10 \mathrm{~cm}$ in the northeastermost outcrops to less than $5 \mathrm{~cm}$ in the Arctic Village area. This distribution of clast sizes suggests that sediment dispersal in the eastern part of the Kanayut was from northeast to southwest.

The pattern of sediment dispersal is apparent from a contour map of clast sizes ( $\mathrm{fig}$. 17). This map is drawn from the information presented in figure 16 and shows the well-defined maximums of clast sizes in the Shainin Lake area and in the northeasternmost outcrops. The geometry of the contour lines around these clast size maximums indicates that sediment transport in both systems was primarily toward the southwest.

A third maximum appears to be present along the northern side of the outcrop belt near the Sagavanirktok River. It may represent a third site of entry of a major river system into the Kanayut depositional system. The minimal bowing of the contour lines south of this third clast-size maximum may indicate that it represents a smaller distributary system than the Shainin Lake and northeastern systems. In addition, the orientation of the contour lines suggests that sediment transport was mostly southerly rather than southwesterly in this possible distributary system.

\section{CONGLOMERATE CLAST COMPOSITION}

\section{Introduction}

Nilsen and others (1980a, 1980b) determined the clast composition of 79 beds of conglomerate from the Kanayut Conglomerate and associated units from 


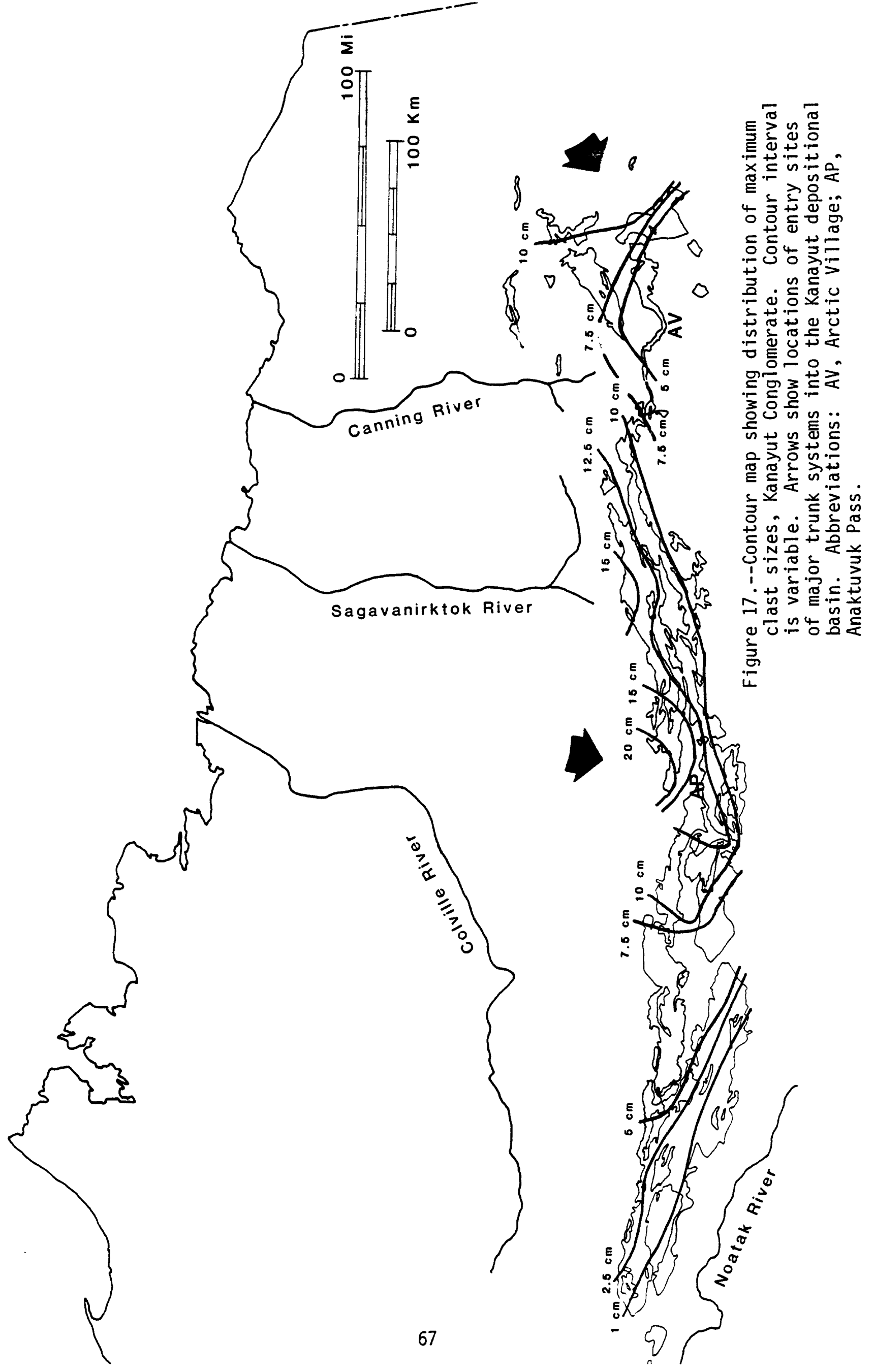


pebble counts during the 1978 and 1979 field seasons. We have added fourteen additional pebble counts from the 1980 field season (Table 1). Five of the new counts are from the lower shale member, six from the middle conglomerate member, and one from the Stuver Member of the Kanayut Conglomerate. Two additional pebble counts are from the basal sandstone member of the Kayak Shale where it had a gradational contact with the Stuver Member. The pebble counts were made by counting one hundred randomly selected clasts larger than $1 \mathrm{~cm}$ in the field, noting the lithic type of each pebble and the longest clast from each count. An additional selective pebble count of only clasts larger than $7 \mathrm{~cm}$ was made in a very coarse bed of conglomerate (maximum clast of 14 $\mathrm{cm}$ ) from the middle conglomerate member near Galbraith Lake to determine the composition of large clasts. Because the size constraint changed the relative abundance of clast types, this pebble count is considered separately.

The conglomerates are generally characterized by a high chert content and lesser amounts of quartz and quartzite. The conglomerates are compositionally very mature, with every count consisting of at least 99 percent chert plus vein quartz plus quartzite conglomerate clasts. This maturity can result from a compositionally mature provenance, extensive chemical weathering, or extreme physical abrasion during transport.

\section{Kanayut Conglomerate}

Forty-seven pebble counts from the fluvial lower shale, middle conglomerate and Stuver Members of the Kanayut Conglomerate were reported by Nilsen and others (1980a, 1981a). Twelve new pebble counts from the Kanayut Conglomerate are presented in this report (Table 1), all obtained from the Shainin Lake and Galbraith Lake areas in the central Brooks Range.

The 1980 data, like the earlier data, show that the Kanayut Conglomerate is dominated by chert clasts. Chert clasts comprise 71 to 89 percent of the Kanayut clasts in the 1980 data and an average of 82 percent of the aggregated 1978, 1979, and 1980 data. Chert is mostly white, gray, and black in color, but at a few locations near Shainin Lake and Galbraith Lake, red chert is present and locally abundant (as much as 45 percent). Vein quartz is a secondary but important constituent, ranging from 10 to 22 percent in the 1980 data and averaging 14 percent in the aggregated 1978-1980 data. Quartzite clasts that are locally coarse grained or conglomeratic are a common minor constituent and range from 2 to 7 percent in the 1980 data and average 3 percent in the aggregated 1978-1980 data.

As noted previously (Nilsen and others, 1981a), other minor clast types include siltstone, phyllite, argillite, and carbonate rocks. These are generally only locally abundant and comprise less than 1 percent of the compiled 1978-1980 fluvial Kanayut data. In the counts made during the 1980 field season, only one pebble count revealed any of these constituents and that contained only 1 percent argillite clasts. The 1980 pebble counts may suggest that the Shain in Lake-Galbraith Lake area is depleted in these minor lithic clast types.

We have plotted our compiled pebble counts from 1978, 1979 and 1980 on ternary diagrams. The first diagram has mature (quartzose) clasts, carbonate clasts, and immature (other lithic) clasts as poles and shows the compositional maturity of the conglomerate (fig. 18). This plot shows that 
all but two of the conglomerates sampled contain more than 80 percent chert, vein quartz, quartzite, and quartzite conglomerate, and only five samples contain less than 90 percent of these constituents. The second ternary diagram has vein quartz, quartzite and chert as poles and illustrates the predominance of chert in most of the pebble counts from the Kanayut

Conglomerate (fig. 19). Several pebble counts plot at the middle part of the vein quartz-chert join away from the main cluster of data. We cannot explain these variations, which appear to be random.

We have plotted clast size versus percent of each clast lithology for the combined 1978, 1979, and 1980 pebble count data from the Kanayut Conglomerate (fig. 20). This diagram again shows that the Kanayut is rich in chert and typically contains a moderate amount of vein quartz and quartzite. It also shows that there is a consistent relationship between percent of quartzite clasts and clast size (fig. 20C). Coarser parts of the Kanayut Conglomerate are enriched in quartzite. Our selective pebble count of only those clasts larger than $7 \mathrm{~cm}$ in longest dimension contains 67 percent quartzite plus quartzite conglomerate, strongly suggesting that quartzite and quartzite conglomerate clasts are more abundant in the coarser fractions of the conglomerate. The enrichment of quartz in this pebble count is at the expense of chert ( 18 percent), suggests that there is less chert in coarser

conglomerate. However, this relationship is not seen in the clast size versus percent of chert diagram ( $\mathrm{fig}$. 20B), perhaps suggesting that provenance plays a dominant role in determining the abundance of chert in finer conglomerates.

The 1980 pebble-count data from the Kanayut Conglomerate plot within the fields for the Kanayut shown in the various diagrams previously reported by Nilsen and others (1981a) and are comparable with the earlier data in every respect. We suggest that this generally consistent conglomerate composition throughout the very extensive Kanayut depositional system indicates that the Kanayut detritus was probably derived from a single major source terrane.

\section{Kayak Shale}

Rare conglomerate in the Kayak Shale is typically associated with shallow-marine sandstone bodies in its basal sandstone. Two pebble counts from conglomerate of the basal sandstone member of the Kayak Shale were made at one location south of Galbraith Lake at the top of measured section of the Stuver Member (fig. 6) during the 1980 field season (Table 1). These counts suggest that the conglomerate of the basal sandstone member of the Kayak Shale, like the Kanayut Conglomerate, is dominated by chert clasts ( 83 percent), has subordinate amounts of vein quartz (average 16 percent), and locally contains minor amounts of quartzite clasts (average 1 percent). The basal sandstone member of the Kayak Shale is interpreted to reflect nearshore deposition in the regressing part of the Kanayut fluvio-deltaic complex (Nilsen and others, 1980a, 1981a). The two Kayak Shale pebble counts are consistent with this interpretation, exhibiting compositional similarity to and plotting well within the fields of the Kanayut data (figs. 18, 19, and 20). 
Table 1.--Maximum clast size and percentage of each clast type from pebble counts of the Kanayut Conglomerate and basal sandstone member of the Kayak Shale.

Kayak Shale, basal sandstone member

Field Maximum Wite Gray Black Red Vein Quartzite

Station Clast Size Chert Chert Chert Chert Quartz Quartzite Conglomerate Argillit

$80 \mathrm{TN}-43$

$80 \mathrm{TN}-43$

3

$15 \quad 36$

15

31

$\begin{array}{ll}32 & 0 \\ 12 & 0\end{array}$

$\begin{array}{lllll}40 & 12 & 0 & 17 & 0\end{array}$

2

0

0

0

0

Kanayut Conglomerate, Stuver Member

$80 \mathrm{TN}-43$

$2.5 \quad 16$

$38 \quad 28$

17

1

0

Kanayut Conglomerate, middle conglomerate member

$80 \mathrm{TN}-44$

$80 \mathrm{TN}-44$

$80 \mathrm{TN}-47$

$80 \mathrm{TN}-47$

80 TN -47

80 IN -47

$* 80 \mathrm{TN}-47$

$\begin{array}{cc}4 & 20 \\ 4 & 12 \\ 12 & 16 \\ 8 & 35 \\ 9 & 37 \\ 6 & 40 \\ 14 * & 0\end{array}$

$14 \quad 14$

$20 \quad 12$

$30 \quad 26$

$23 \quad 17$

24

23

11

39
45
0
0
0
0
0

13
10
22
17
20
22
15

$\begin{array}{rr}0 & 0 \\ 1 & 0 \\ 5 & 1 \\ 7 & 1 \\ 5 & 0 \\ 6 & 1 \\ 24 & 43\end{array}$

24

0
0
0
0
0
0
0

Kanayut Conglomerate, lower shale member

$80 \mathrm{TN}-12$

$80 \mathrm{TN}-12$

$80 \mathrm{TN}-12$

$80 \mathrm{TN}-46$

$80 \mathrm{TN}-46$

$\begin{array}{llll}3 & 28 & 41 & 18 \\ 4 & 42 & 26 & 14 \\ 5 & 30 & 35 & 14 \\ 3 & 14 & 40 & 26 \\ 2 & 22 & 31 & 32\end{array}$

$\begin{array}{ll}0 & 11 \\ 0 & 13 \\ 0 & 15 \\ 2 & 18 \\ 2 & 13\end{array}$

2
4
6
0
0
0
0
0
0

* Only clasts larger than $7 \mathrm{~cm}$ were included in this count. 


\section{CARBONATE CLASTS}

\section{A. Basal Sandstone}

Member, Kayak Shale

\section{B. Kanayut} Conglomerate

\section{IMMATURE}

\section{(OTHER LITHIC) CLASTS}

Figure 18.---Immature clast (argillite, siltstone, sandstone, and greenstone)-carbonate clast--mature clast (chert, vein quartz, and quartzite) ternary diagram from pebble counts made during the 1978, 1979, and 1980 field seasons. A, Basal sandstone member of the Kayak Shale. B, Kanayut Conglomerate. 


\section{A. Basal Sandstone Member, Kayak Shale}

\section{B. Kanayut}

Conglomerate

\section{QUARTZITE}

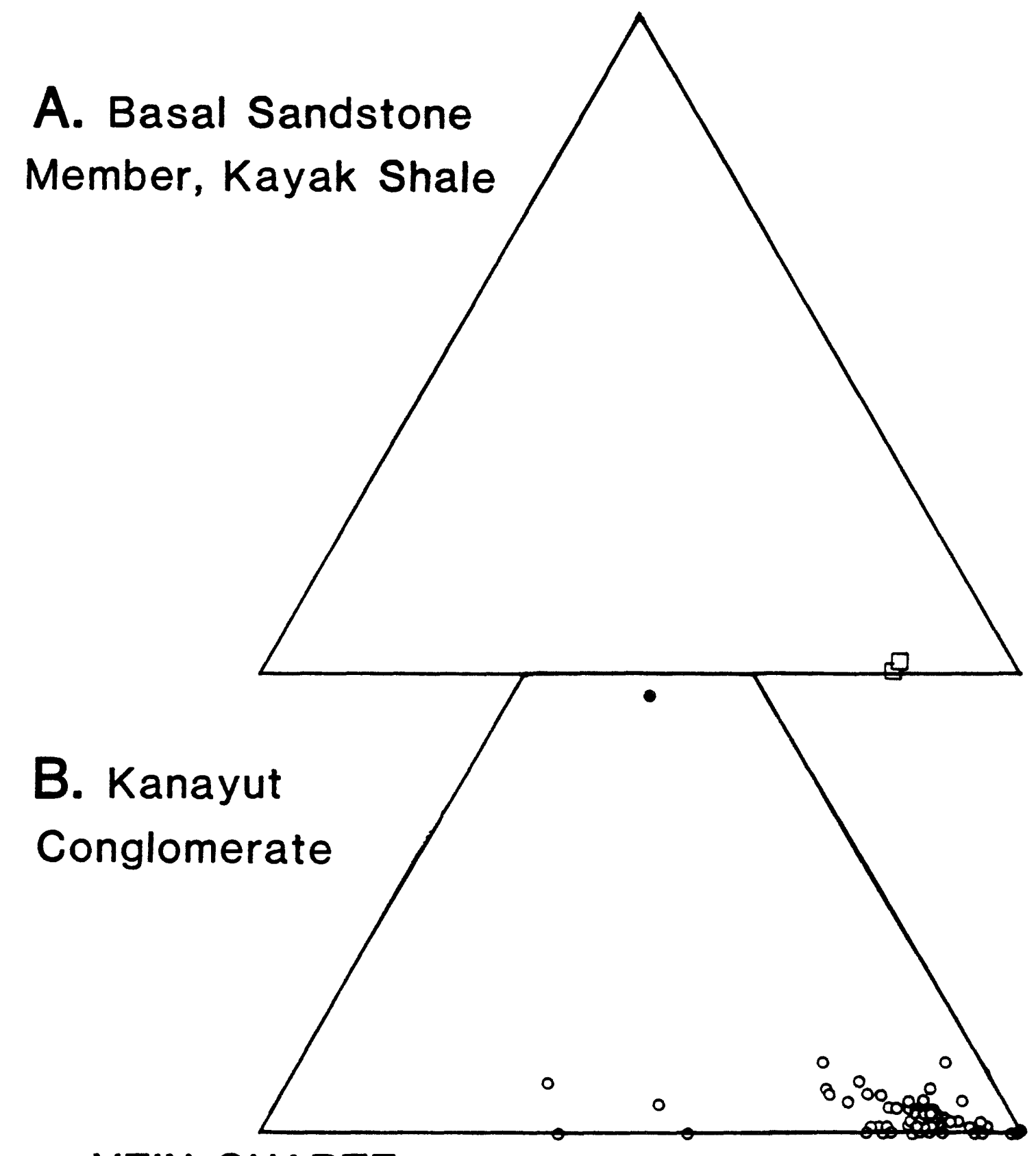
VEIN QUARTZ

Figure 19.--Vein quartz--quartzite--chert ternary diagram from pebble counts made during the 1978,1979 , and 1980 field seasons. A, Basal sandstone member of the Kayak Shale. B, Kanayut Conglomerate. 
Figure 20.--Plots of maximum clast size versus percentage of clast lithology for the Kanayut Conglomerate from pebble counts made during the 1978, 1979, and 1980 field seasons. A, Vein quartz. B, Chert. C, Quartzite. Open circles represent pebble counts with a minimum clast size larger than $1 \mathrm{~cm}$; filled circles represent those with a minimum clast size larger than $7 \mathrm{~cm}$. 


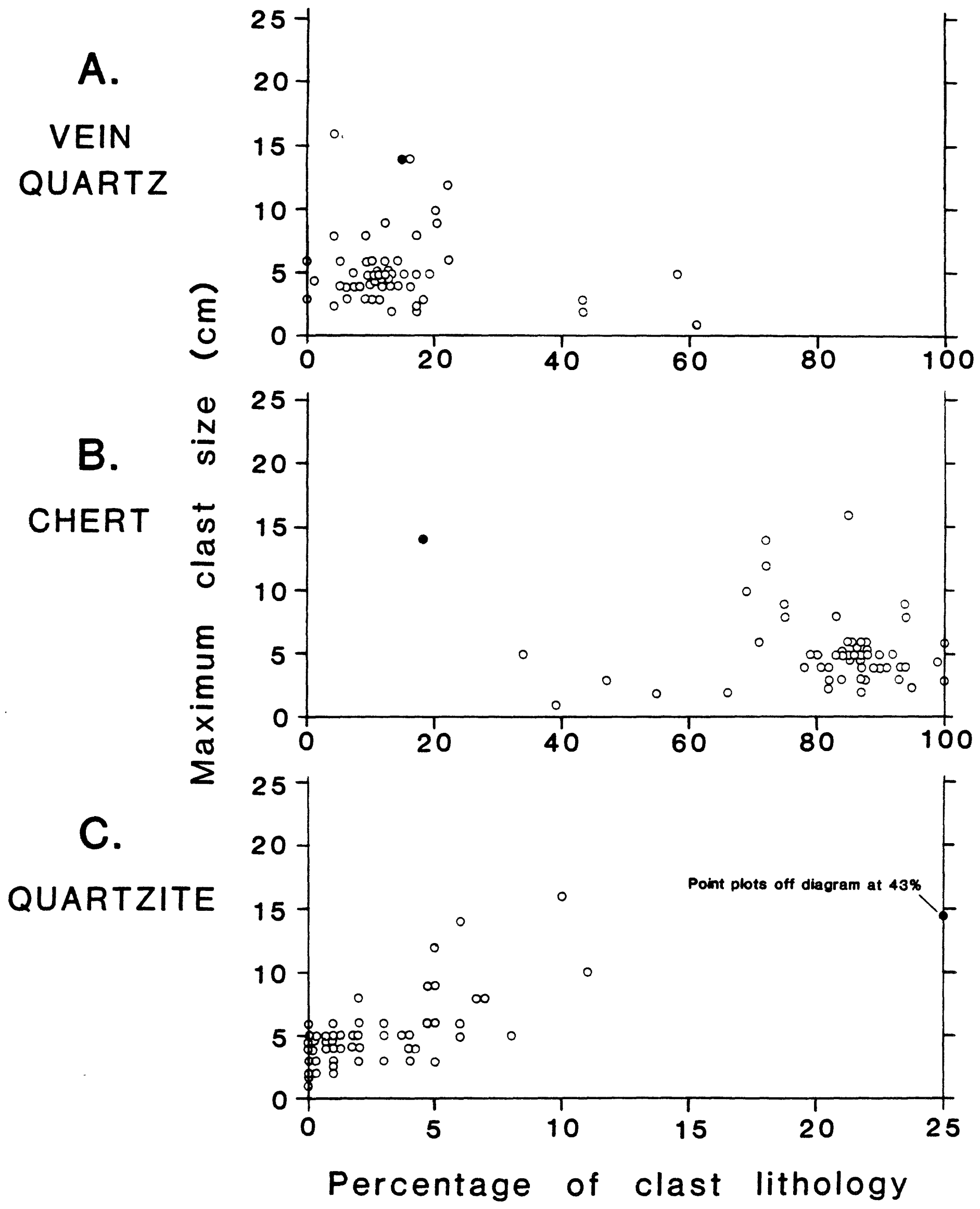




\section{PALEOCURRENTS}

\section{Introduction}

Nilsen and others (1980) plotted 166 paleocurrent measurements made in 1978 from the Kanayut Conglomerate, Kekiktuk Conglomerate and Kayak Shale. During the 1979 field season, an additional 292 paleocurrent measurements were collected from these units and the Hunt Fork Shale and Beaucoup Formation at 63 separate locations (Nilsen and others, 1981). Data from both years were compiled and presented in map form (Nilsen and others, 1980b). An additional 316 measurements were collected during the 1980 field season from the Hunt Fork Shale, Kanayut Conglomerate, and Kayak Shale, bringing the total to 774 determinations for all three seasons (figs. 21 and 22).

Sedimentary features measured include medium-scale tabular and trough cross-strata (447 measurements), conglomerate imbrication and long-axis orientation ( 188 measurements), primary current lineation ( 83 measurements), ripple markings ( 33 measurements), flute marks ( 9 measurements), pebble trains and erosional scours ( 4 measurements of each), channel margins, fluid-escape folds, and ball and pillow structure ( 1 measurement of each). Restorations of paleocurrent directions to the horizontal were done manually on a stereonet. Computer-calculated vector means and standard deviations were determined for 37 locations at which more than four paleocurrent measurements were made and also for the total number of paleocurrent measurements from each of the various stratigraphic units. Bidirectional features such as primary current lineation were assigned a westerly or southerly sense because of the preponderance of unidirectional indicators with that orientation.

\section{Hunt Fork Shale}

Ten paleocurrent determinations were obtained from the Hunt Fork Shale at 5 separate locations during the 1979 field season (Nilsen and others, sheet 2). An additional 21 measurements collected during the 1980 field season from 7 separate locations brings the total to 31 determinations, including 17 of trough cross-strata, 8 of primary current lineations, 3 of tabular crossstrata, 2 of oscillation ripple markings, and 1 flute mark. The azimuthal vector mean and standard deviation of all measurements from the Hunt Fork Shale are $207^{\circ}+54^{\circ}$, reflecting the overall southerly sediment transport direction (fig. 22). The relative consistency of these data probably indicates that sediment was chiefly transported offshore. A few measurements which show significant deviation from the mean may result from storm-generated currents affecting sediments deposited in shallower water.

\section{Fluvial members of Kanayut Conglomerate}

In our report of the 1978 field season, we plotted 158 paleocurrent measurements from the fluvial lower shale, middle conglomerate and Stuver members of the Kanayut Conglomerate (Nilsen and others, 1980a). During the 1979 field season, we measured an additional 156 paleocurrent directions at 35 separate locations. The orientation of the measurements was compiled and plotted in map form and by summary rose diagram (Nilsen and others, 1980b), sheet 1). An additional 291 determinations were collected during the 1980 field season, bringing the total number of measurements to 605 which include 249 trough cross-strata, 170 clast imbrication and long-axis orientations, 88 tabular cross-strata, 60 primary current lineations, 16 current ripple 


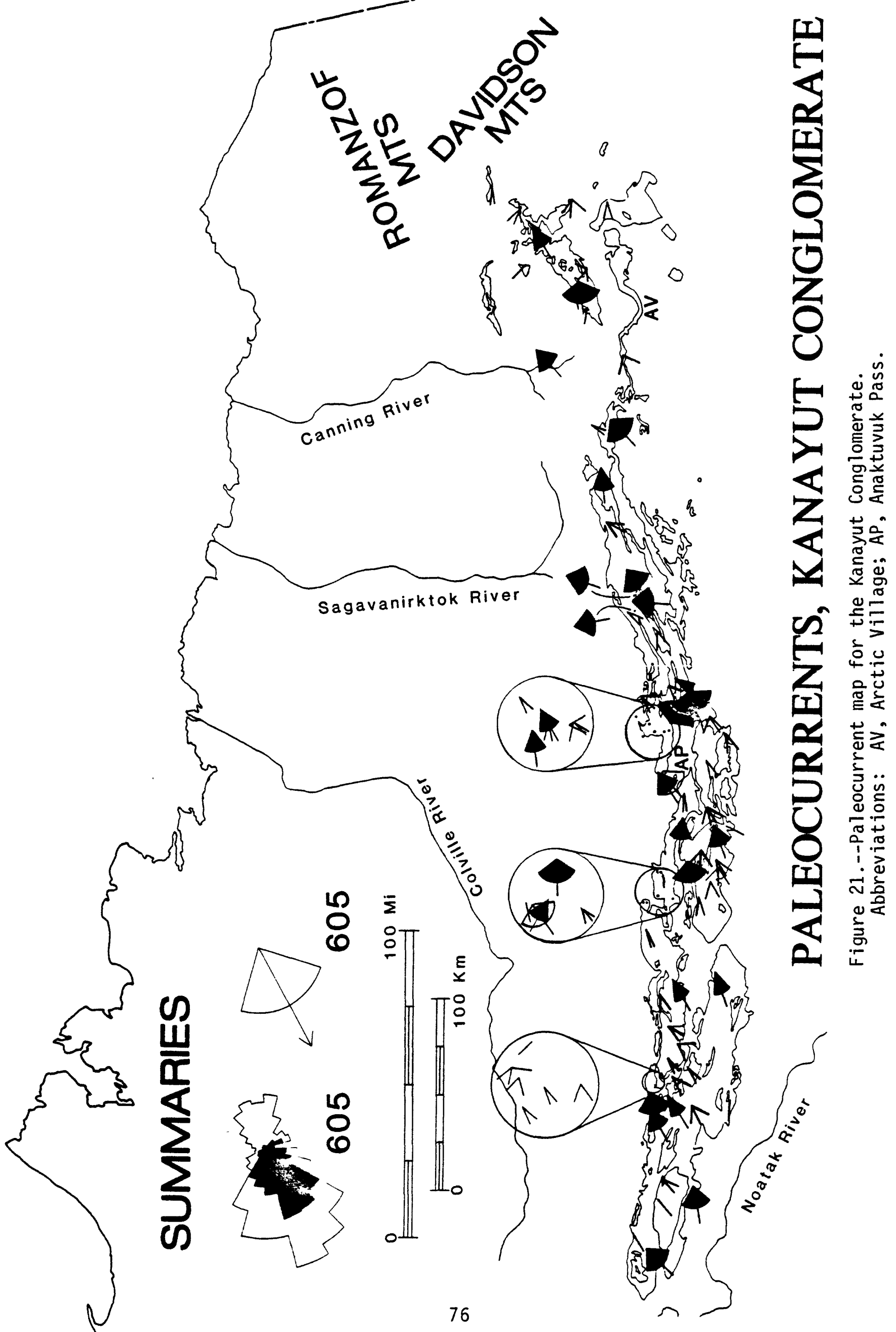


markings, 8 flute marks, 4 pebble trains, 4 erosional scours, 2 aligned plant fragments, 2 oscillation ripple markings, 1 channel-margin orientation, and 1 fluid escape fold ( $\mathrm{fig} .21$ ).

Unidirectional indicators show a southwest transport of sediment, and bidirectional indicators (those giving sense of transport only) show westsouthwest or east-northeast transport. The azimuthal vector mean and standard deviation of all measurements from the Kanayut is $243^{\circ}+450$. Although the local orientation of paleocurrents is as southerly as $1720+280$ for locations having more than four measurements, the overall southwesterly transport direction is consistent between members as shown by a calculation of 2430 . $47^{\circ}$ for the lower shale member (209 measurements), $245^{\circ}+40^{\circ}$ for the middle conglomerate member (247 measurements), and $234^{\circ}+61^{\circ}$ for the Stuver Member (128 measurements), with 31 paleocurrent determinations unassigned to stratigraphic units. These data indicate that the fluvial sediment transort direction was predominantly toward the southwest throughout the entire time of deposition of the Kanayut Conglomerate. Donovan and Tailleur (1975) previously determined southerly directions of transport for the Kanayut.

\section{Kayak Shale}

Three paleocurrent measurements from current ripple markings in the shallow-marine or intertidal basal sandstone member of the Kayak Shale were previously reported (Nilsen and others, 1980a). An additional 10 measurements were collected during the 1979 field season (Nilsen and others, 1980b, sheet 2) and 6 more during the 1980 field season. The total number of measurements include 8 current ripple markings, 5 oscillation ripple markings, 4 tabular cross-strata, 1 long-axis orientation, and 1 ball and pillow structure.

Although the sediment transport direction given by the measurements is relatively consistent at each location, there is considerable variability in data between locations ( $\mathrm{fig} .21$ ). Because of this geographic variation, the significance of the vector mean and standard deviation $(1200 \pm 790)$ is relatively minor. We attribute the variability of paleocurrent measurements in the Kayak Shale to alternating offshore, onshore, and longshore sediment transport related to wave-, wind-, storm-, and tide-generated currents.

\section{SUMMARY}

This report summarizes stratigraphic and sedimentologic data collected during the 1980 field season in the central Brooks Range from the Upper Devonian and Lower Mississippian Endicott Group. The Upper Devonian Kanayut Conglomerate consists of a basal marine sandstone member and three successive fluvial members. It crops out for about $1000 \mathrm{~km}$ along strike and about $50 \mathrm{~km}$ across strike in at least three major thrust plates in the central part of the Brooks Range. The basal marine sandstone member was probably deposited as channel-mouth bars, offshore bars, and'spits. The overlying lower shale member is inferred to have been deposited by meandering streams over a large floodplain area. The middle conglomerate member, which contains the coarsest conglomerate and little or no shale, was probably deposited by braided streams. The Stuver Member is inferred to have been deposited by meandering streams and is overlain by intertidal and shallow-marine sandstone at the base of the Kayak Shale. 


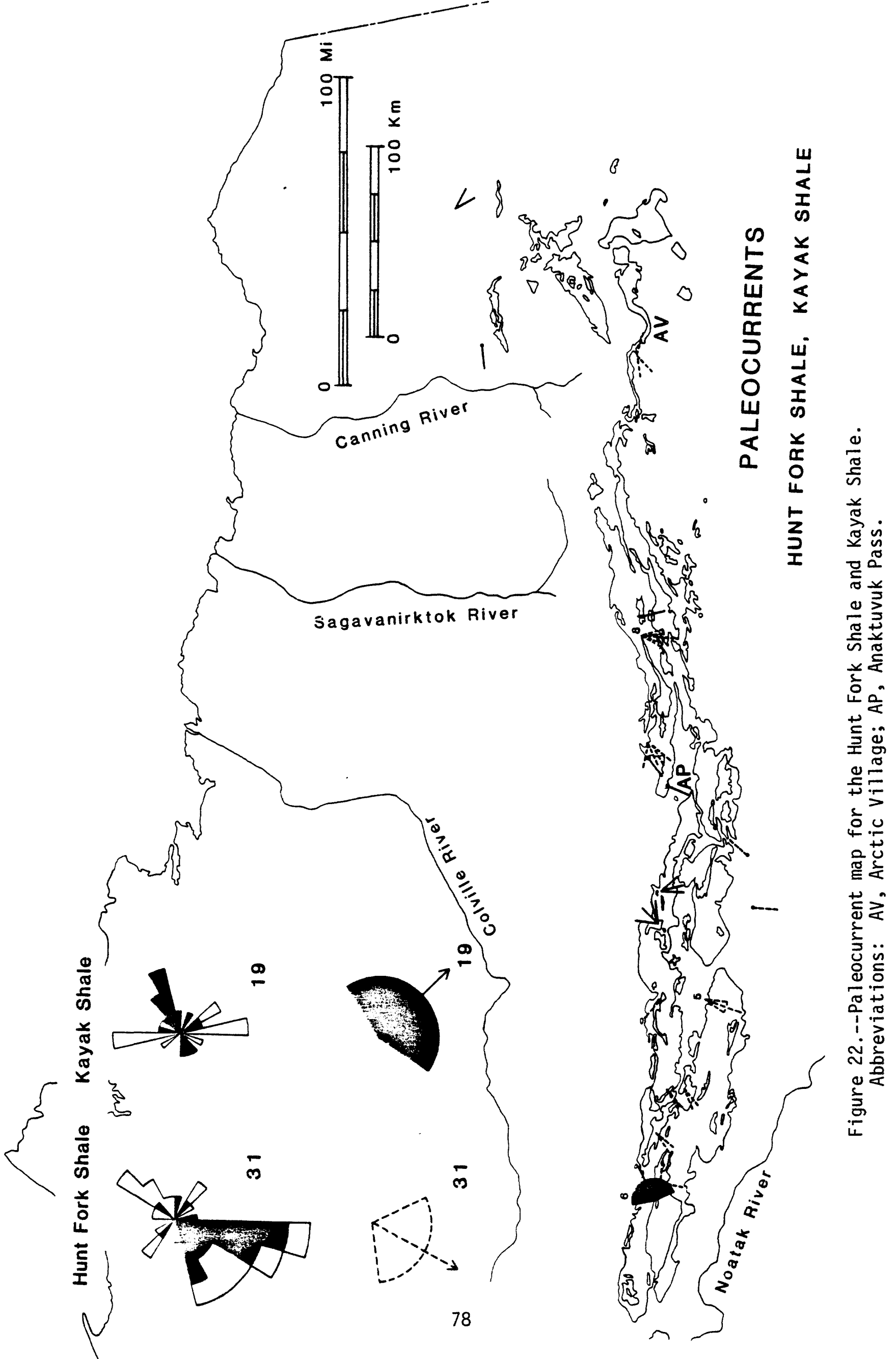


The maximum clast size of conglomerate decreases westward, southward, and eastward from the Shainin Lake area, suggesting that a major trunk stream originally entered the depositional basin in this area. A second major trunk stream probably entered the depositional basin at its northeastern end.

The composition of the Kanayut Conglomerate clasts varies little from place to place or member to member. In most of the conglomerates examined, about 80-95 percent of the pebbles are chert, about 5-15 percent quartz, and 1-5 percent quartzite. Red chert clasts are locally abundant in the Shainin Lake and Galbraith Lake area. Pebbles of argillite and other rock fragments are rare.

The orientations of cross-strata, primary current lineations, current ripple marks, and imbrication and long axes of pebbles in the three fluvial members of the Kanayut consistently show sediment transport toward the southwest across most of the central and eastern Brooks Range. Paleocurrents reported from the 1980 field season indicate more southerly transport in the Atigun River area.

The facies sequence in the Hunt Fork Shale and Kanayut Conglomerate suggests that the Kanayut comprises the marginal-marine and fluvial parts of a prograding delta system. The consistent southwestward direction of paleocurrents in the fluvial deposits, together with the southwestward decrease of grain size, suggests an eastern, northern, or northeastern source, although the allochthonous nature of the outcrop belt precludes identification of the source at present. Judging from the abundance of chert, quartz, and quartzite clasts in the Kanayut, the source terrane was probably composed mostly of slightly metamorphosed sedimentary rocks. The high roundness and sphericity of the clasts and their compositional maturity indicate that the source terrane may also have included older conglomerates. 
Bowsher, A. L., and Dutro, J. T., Jr., 1957, The Paleozoic section in the Shainin Lake area, central Brooks Range, Alaska: U.S. Geological Survey Professional Paper 303-A, p. 1-39.

Brosge, W. P., Dutro, J. T., Jr., Mangus, M. D., and Reiser, H. N., 1962, Paleozoic sequence in eastern Brooks Range, Alaska: American Association of Petroleum Geologists Bulletin, v. 46, no. 12, p. 2174-2198.

Brosge, W. P., Nilsen, T. H., Moore, T. E., and Dutro, J. T., Jr., in press, Geology of the Upper Devonian and Lower Mississippian(?) Kanayut Conglomerate, Brooks Range, Alaska: U.S. Geological Survey Professional Paper on the National Petroleum Reserve, Alaska.

Brosge, W. P., and Reiser, H. N., 1962, Preliminary geologic map of Christian quadrangle, Alaska: U.S. Geological Survey Open-File Map OF-62-15, scale $1: 250,000$

----,1964, Geologic Map and section of the Chandalar quadrangle, Alaska: U.S. Geological Survey Open-File Map I-375, scale 1:250,000. ,1965 Preliminary geologic map of the Arctic quadrangle, Alaska: U.S. Geological Survey Open-File Report OF-65-22, scale 1:250,000. ,1969, Preliminary geologic map of Coleen quadrangle, Alaska: U.S. Geological Survey Open-File Report OF-69-25, scale 1:250,000. ,1971, Preliminary bedrock geologic map, Wiseman and eastern Survey Pass quadrangles, Alaska: U.S. Geological Survey Open-File Report $0-71-56,2$ sheets, scale $1: 250,000$.

Brosge, W. P., Reiser, H. N., Dutro, J. T., Jr., and Detterman, R. L., 1976, Reconnaissance geologic map of the Table Mountain quadrangle, Alaska: U.S. Geological Survey Open-File Map 76-546, 2 sheets, scale 1:200,000. ,1979a, Bedrock geologic map of the Philip Smith Mountains quadrangle, Alaska: U.S. Geological Survey Miscellaneous Field Studies Map MF-879B, 2 sheets, scale 1:250,000.

Brosge, W. P., Reiser, H. N., Dutro, J. T., Jr, and Nilsen, T. H., 1979b, Geologic map of Devonian rocks in parts of the Chandler Lake and Killik River quadrangles, Alaska: U.S. Geological Survey Open-File Map OF-791224 , scale $1: 200,000$.

Carter, C., and Laufeld, S., 1975, Ordovician and Silurian fossils in well cores from North Slope of Alaska: American Association of Petroleum Geologists Bulletin, v. 59, no. 3, p. 457-464.

Chapman, R. M., Detterman, R. L., and Mangus, M. D., 1964, Geology of the Killik-Etivluk Rivers region, Alaska: U.S. Geological Survey Professional Paper 303-F, p. 325-407.

Collins, F. R., 1958, Test wells, Topogoruk area, Alaska: U.S. Geological Survey Professional Paper 305-D, p. 265-316.

Dillon, J. T., Pessel, G. H., Chen, J. H., and Veach, N. C., 1980, Middle Paleozoic magmatism and orogenesis in the Brooks Range, Alaska: Geology, v. 8 , p. $338-343$.

Donovan, T. J., and Tailleur, I. L., 1975, Map showing paleocurrent and clastsize data from the Devonian-Mississippian Endicott Group, northern Alaska: U.S. Geological Survey Miscellaneous Field Studies Map MF-692, scale $1: 7,500,000$.

Dutro, J. T., Jr., Brosge, W. P., Detterman, R. L., and Reiser H. N., 1979, Beaucoup Formation, a new Upper Devonian stratigraphic unit in the Central Brooks Range, northern Alaska, in Sohl, N. F., and Wright, W. B., eds., Changes in stratigraphic nomenclature by the U.S. Geological Survey, 1978: U.S. Geological Survey Bulletin 1482-A, p. A63-A69. 
Mayfield, C. F., and Tailleur, I. L., 1978, Bedrock geology map of the Ambler River quadrangle, Alaska: U.S. Geological Survey Open-File Map 78-120A, scale $1: 250,000$.

Mayfield, C. F., Tailleur, I. L., Mull, C. G., and Sable, E. G., 1978, Bedrock geologic map of the south half of National Petroleum Reserve in Alaska:

U.S. Geological Survey Open-File Map OF-78-70B, 2 sheets, scale $1: 500,000$.

Mull, C. G., and Mangus, M. D., 1972, Itkilyariak Formation: New Mississippian formation of Endicott Group, Arctic slope of Alaska: American

Association of Petroleum Geologists Bulletin, v. 56, no. 8, p. 1364-1369.

Mull, C. G., Tailleur, I. L., Mayfield, C. F., and Pessel, G. H., 1976, New structural and stratigraphic interpretations, central and western Brooks Range and Arctic slope: U.S. Geological Survey Circular 773, p. 24-26.

Nelson, S. W., and Grybeck, Donald, 1980, Geologic map of the Survey pass quadrangle, Alaska: U. S. Geological Survey Miscellaneous Field Studies Map MF-1176-A, scale 1:250,000.

Nilsen, T. H., in press, Upper Devonian and Lower Mississippian redbeds, Brooks Range, Alaska, in Miall, A. D., ed., Molasse: Canadian Society of Petroleum Geologists Memoir.

Nilsen, T. H., Moore, T. E., Dutro, J. T., Jr., Brosge, W. P., and Orchard, D. M., 1980a, Sedimentology and stratigraphy of the Kanayut Conglomerate and associated units, central and eastern Brooks Range, Alaska--Report of the 1978 field season: U.S. Geological Survey Open-File Report 80-888, 40 p.

Nilsen, T. H., Moore, T. E., and Brosge, W. P., 1980b, Paleocurrent maps for the Upper Devonian and Lower Mississippian Endicott Group, Brooks Range, Alaska: U.S. Geological Survey Open-File Report 80-1066, scale $1: 1,000,000$.

Nilsen, T. H., Moore, T. E., Brosge, W. P., and Dutro, J. T., 1981 , Sedimentology and stratigraphy of the Kanayut Conglomerate and associated units, Brooks Range, Alaska--Report of 1979 field season: U.S. Geological Survey Open-file Report 81-506, $37 \mathrm{p}$.

Porter, S. C., 1966, Stratigraphy and deformation of Paleozoic section at Anaktuvuk Pass, central Brooks Range, Alaska: American Association of Petroleum Geologists Bulletin, v. 50, no. 5, p. 952-980.

Reed, B. L., 1968, Geology of the Lake Peters area, northeastern Brooks Range, Alaska: U.S. Geological Survey Bulletin 1236, 132 p.

Reiser, H. N., Brosge, W. P., Dutro, J. T., Jr., and Detterman, R. L., 1971, Preliminary geologic map, Mt. Michelson quadrangle, Alaska: U.S. Geological Survey Open-File Report OF-71-237, scale 1:200,000. ,1974, Preliminary geologic map of the Demarcation point quadrangle, Alaska: U.S. Geological Survey Miscellaneous Field Studies Map MF-610, scale $1: 250,000$.

Tailleur, I. L., Brosge, W. P., and Reiser, H. N., 1967, Palinspastic analysis of Devonian rocks in northwestern Alaska, in Oswald, D. H., ed., International Symposium on the Devonian System: Alberta Society of Petroleum Geologists, v. 2, p. 1345-1361.

Tetra Tech, Inc., 1979, Seismic survey data, National Petroleum Reserve in Alaska, revised May 1978: National Oceanographic and Atmospheric Administration, Environmental Data and Information Service, 10 maps. 